Prana Ugiana Gio

Rezzy Eko Caraka

Dian Utami Sutiksno

Ansari Saleh Ahmar

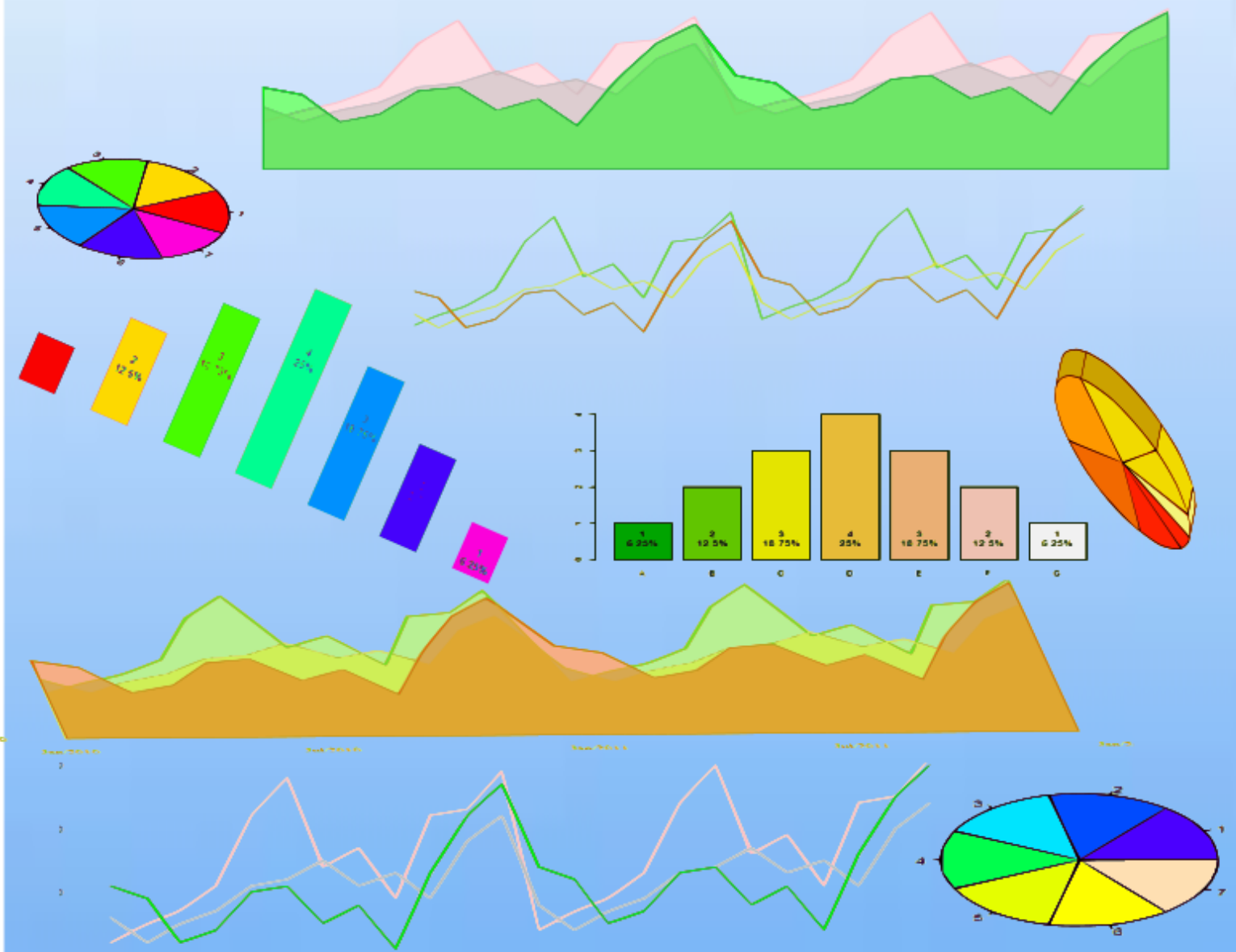

Membuat Berbagai Grafik dengan STATCAL-VISUALIZATION 


\section{Membuat Berbagai Grafik dengan STATCAL-VISUALIZATION}

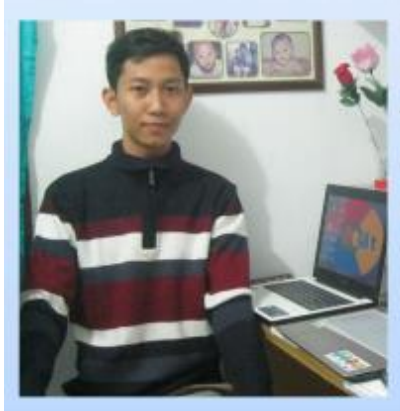

Prana Ugiana Gio (CEO STATCAL), lahir di Tanjung Pinang, 1 Okto ber 1989. Menyelesaikan Program Studi S1 Matematika di Universi tas Sumatera Utara (USU) 2012 dan S2 Matematika USU 2014. Sa at ini sedang melanjutkan pendidikan S3 Matematika (2017-seka rang) di USU. Prana Ugiana Gio mendirikan konsultan olah data me dan, yang mana telah membimbing mahasiswa S1, S2, dan S3 da lam bidang pengolahan data lebih dari 1300 klien selama 3 tahun.

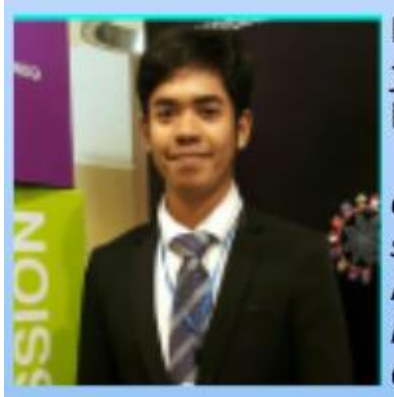

Rezzy Eko Caraka (CFO STATCAL) lahir pada 27 Januari 1994 di Tan jung Balai Karimun Provinsi Kepulauan Riau. Menyelesaikan Pendidi kan S1 Statistika Universitas Diponegoro dengan masa studi 3 tahun 5 bulan pada tahun 2015 dan S2 by research School of Mathemati cal Sciences Faculty of Science and Technology The National Univer sity of Malaysia dengan bidang riset Statistics and data science. Pada Agustus 2017 Mendapatkan penghargaan dari Malaysia Digital Econo my Corporation (MDEC) pada kegiatan Big Data Analysis in Medicine dan Best TalentJALUMA@4.0 Ministry of Higher Education Malaysia.

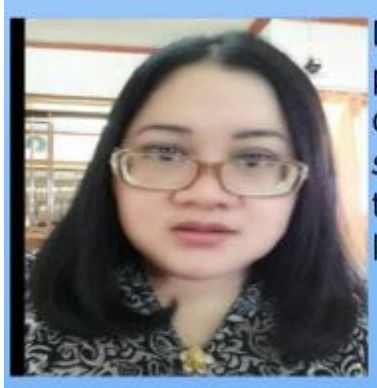

Dian Utami Sutiksno (Promotion and Brand STATCAL), menempuh pendidikan S3 (Doktor Ilmu Manajemen) Universitas Padjadjaran Ban dung, kompetensi management, strategic management, marketing dan strategic marketing. Dosen tetap PNS di Politeknik Negeri Ambon sejak tahun 2001, selain sebagai aktifis sosial di beberapa LSM, juga aktif da lam organisasi profesi Dosen Indonesia.

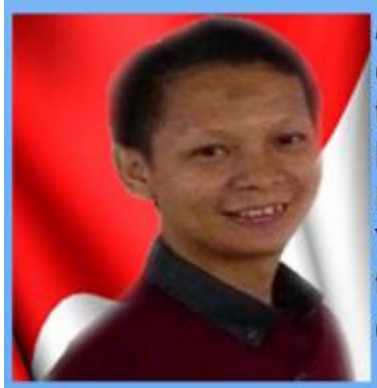

Ansari Saleh Ahmar (Copyright STATCAL), lahir tanggal 16 April 1988 di Kabupaten Takalar Propinsi Sulawesi Selatan. Gelar Sarjana Matema tika (Sarjana Sains) diperoleh Tahun 2009 tepatnya tanggal 14 Novem ber 2009. Pada Tahun 2010 berkesempatan melanjutkan studi-nya di Program Pascasarjana S2 Matematika (M.Sc.) Universitas Gadjah Mada, Yogyakarta tahun 2012. Saat ini, menjadi Dosen Program Studi Statis tika FMIPA Universitas Negeri Makassar dan juga merupakan Presiden dari Komunitas Kolaborasi Publikasi Indonesia (KO2PI). 


\title{
Membuat Berbagai Grafik dengan STATCAL-VISUALIZATION
}

\author{
Prana Ugiana Gio (CEO STATCAL) \\ Rezzy Eko Caraka (CFO STATCAL)
}

\section{Belajar Secara Online di Youtube dengan Channel "Ugi Statistics"}

\section{Download STATCAL di: WWW.statcal.com www.rezzyekocaraka.com}

Sitasi Tulisan Kami:

APA

Gio, P. U., Caraka, R. E., sutiksno, D. u, \& Ahmar, A. S. (2018, August 17). Membuat Berbagai Grafik dengan STATCAL-VISUALIZATION. https://doi.org/10.17605/OSF.IO/HM5AW

MLA

Gio, Prana U et al. "Membuat Berbagai Grafik Dengan STATCAL-VISUALIZATION." Open Science Framework, 17 Aug. 2018. Web.

Chicago

Gio, Prana U, Rezzy E Caraka, Dian u sutiksno, and Ansari S Ahmar. 2018. "Membuat Berbagai Grafik Dengan STATCAL-VISUALIZATION." Open Science Framework. August 17. doi:10.17605/OSF.IO/HM5AW.

DOI 10.17605/OSF.IO/HM5AW 


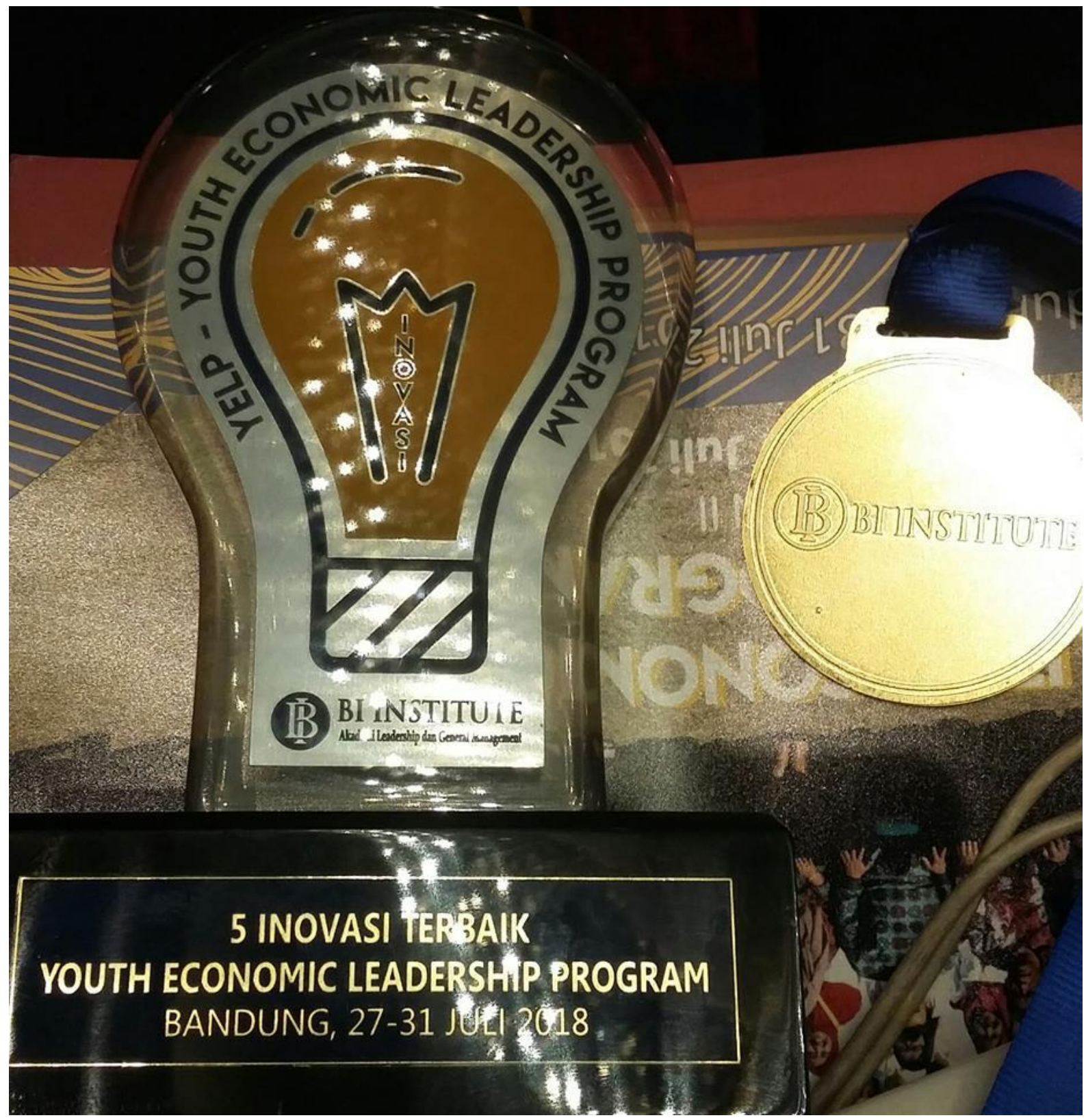

Dari 40 Start Up yg mengikuti kegiatan Youth Economic Leadership Program-Bank Indonesia Institute (YELP-BINS) pada 27-31 Juli 2018, STATCAL masuk ke dalam 5 terbaik 


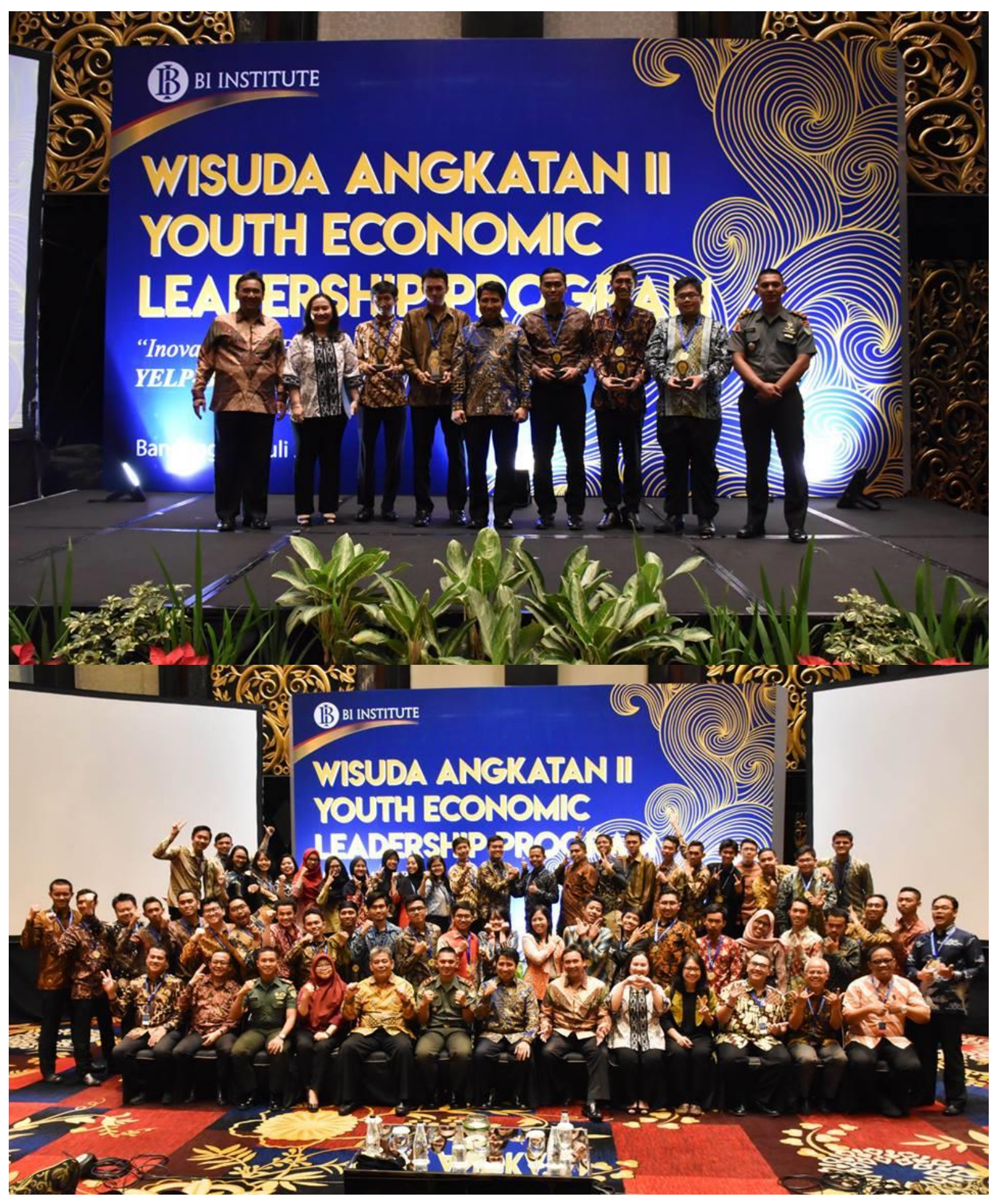




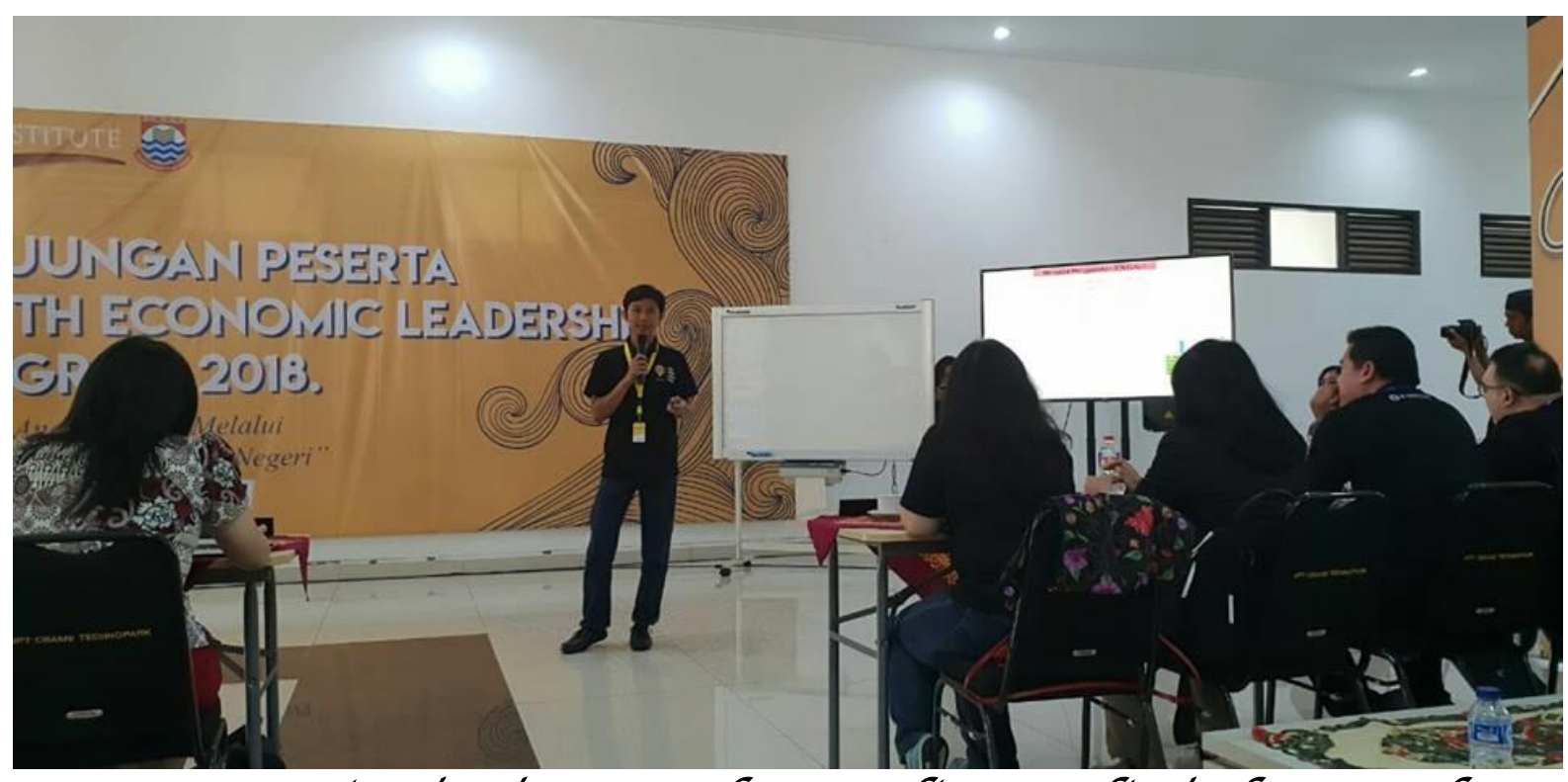

Presentasi STATCAL pada 31 Julí 2018 di Techno Park, Címahi, dì depan para investor 


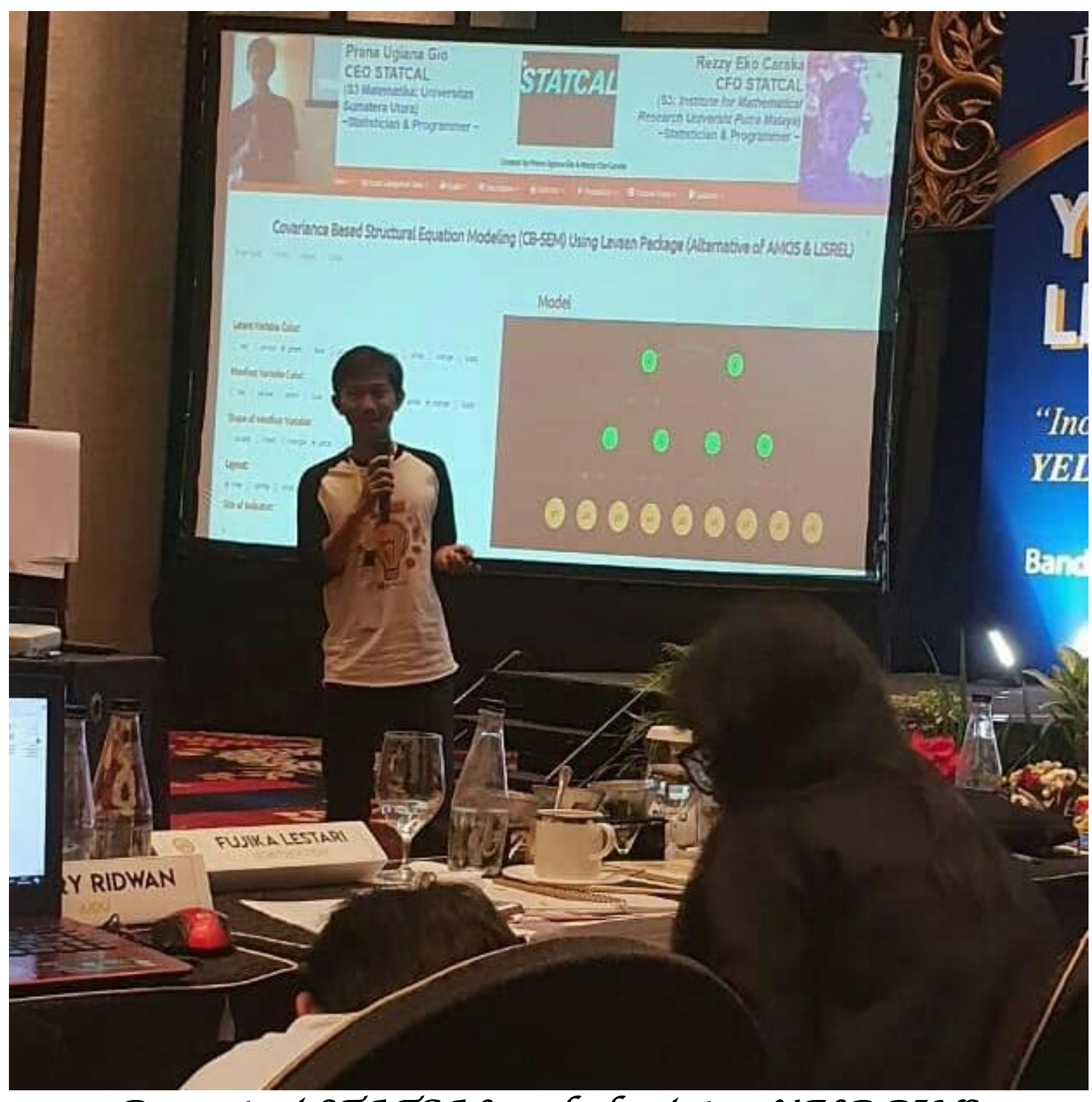

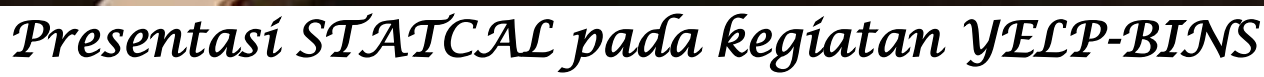
27-31 Julí 2018 


\section{$\mathcal{K} \mathcal{A} \mathcal{T A}$ PENGAJNTAR}

Alhamdulillah, puji syukur atas kehadirat Allah SWT, karena atas izin-Nya, penulis dapat terus mempertahankan semangat untuk menulis, dan akhirnya dapat menyelesaikan tulisan ini. Hadirnya tulisan ini, tidak semata-mata atas usaha penulis sendiri, melainkan atas izin-Nya. Sungguh suatu kebahagiaan bagi penulis bisa berbagi sebagian kecil ilmu pengetahuan milik-Nya melalui tulisan yang berjudul "Membuat Berbagai Grafik dengan STATCAL-VISUALIZATION".

Ucapan terima kasih penulis sampaikan kepada semua pihak yang telah membantu dalam rangka penyelesaian tulisan ini. Penulis menyadari bahwa tulisan ini tentunya masih perlu perbaikan, sehingga penulis mengharapkan kritik dan saran yang membangun dari para pembaca agar tulisan ini dapat menjadi lebih baik. Kritik dan saran dapat ditujukan ke alamat email gioprana89@gmail.com.

Medan, 27 April 2018

Prana Ugiana Gio

Rezzy Eko Caraka

Dian Utami Sutiksno

Ansari Saleh Ahmar 


\section{DAFTAR ISI}

Bab 1 Sekilas STACAL-VISUALIZATION

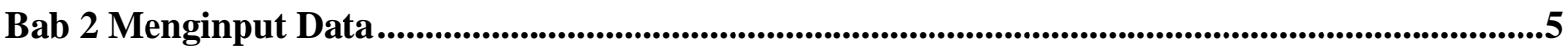

2.1 Persiapan Data...............................................................................................................................................

2.2 Menginput Data Kategori di STATCAL-VISUALIZATION .......................................................6

2.3 Menginput Data Numerik di STATCAL-VISUALIZATION..................................................9

2.4 Data Kosong (Not Available / NA) ...................................................................................................................12

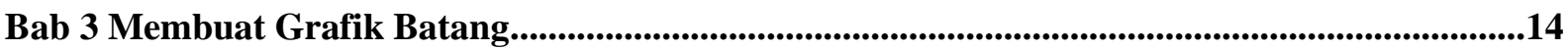

3.1 Membuat Grafik Batang Frekuensi (Input: Satu Variabel Kategori) ..........................................14

3.2 Membuat Grafik Batang Frekuensi (Input: Dua Variabel Kategori) .........................................18

3.3 Membuat Grafik Batang Frekuensi (Input: Lebih dari Dua Variabel Kategori) .....................21

3.4 Membuat Grafik Batang Rata-Rata (Input: Lebih dari Satu Variabel Numerik) ...................23

3.5 Membuat Grafik Batang Rata-Rata (Input: Lebih dari Satu Variabel Numerik dan

Satu Variabel Kategori) ................................................................................................................................25

Bab 4 Membuat Grafik Garis ..................................................................................................................................28

4.1 Membuat Grafik Garis Frekuensi (Input: Satu Variabel Kategori) ..............................................28

4.2 Membuat Grafik Garis Rata-Rata (Input: Lebih dari Satu Variabel Numerik) ......................32

4.3 Membuat Grafik Garis Rata-Rata (Input: Satu Variabel Numerik dan Satu Variabel

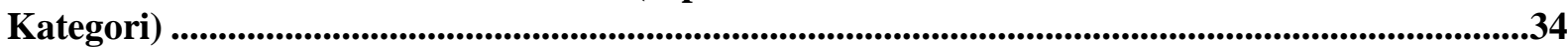

4.4 Membuat Grafik Garis Rata-Rata (Input: Lebih dari Satu Variabel Numerik dan

Satu Variabel Kategori) ..........................................................................................................................................35

4.5 Membuat Grafik Garis Rata-Rata (Input: Satu Variabel Numerik dan Dua Variabel

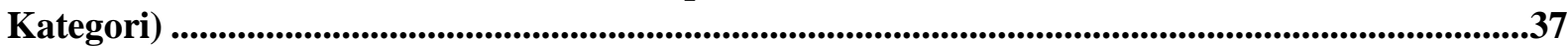

Bab 5 Membuat Grafik Lingkaran......................................................................................................................39

5.1 Membuat Grafik Lingkaran Frekuensi (Input: Satu Variabel Kategori) ...................................39

5.2 Membuat Grafik Lingkaran Frekuensi (Input: Dua Variabel Kategori) ....................................43

Bab 6 Membuat Grafik Boxplot................................................................................................................46

6.1 Membuat Grafik Boxplot (Input: Lebih Dari Satu Variabel Numerik) ....................................46

6.2 Membuat Grafik Boxplot (Input: Satu Variabel Kategori dan Lebih dari Satu

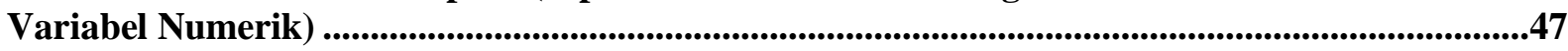

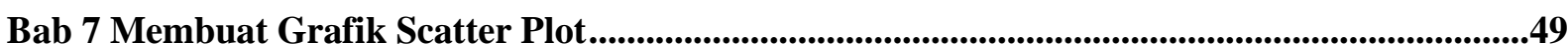

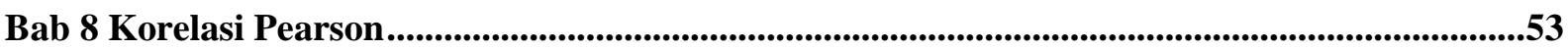

Bab 9 Membuat Grafik Time Series.....................................................................................................................57

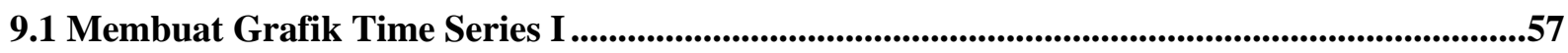

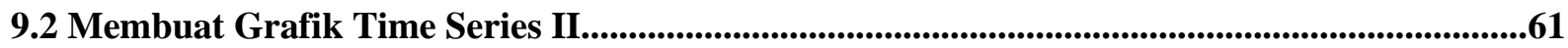




\section{BAB 1}

\section{SEKILAS STATCAL-VISUALIZATION}

STATCAL-VISUALIZATION merupakan program aplikasi berbasis website yang dikhususkan untuk membuat berbagai grafik, seperti grafik batang, garis, lingkaran, korelasi, scatter plot, dan sebagainya. Berbasis website maksudnya ketika program aplikasi STATCAL-VISUALIZATION dijalankan, maka suatu browser (misal: Google Chrome, Firefox, Internet Explorer, Opera, dan sebagainya) akan jalan secara otomatis. Di browser tersebutlah Anda bekerja, mulai dari menginput data dan menampilkan berbagai grafik yang Anda inginkan.

STATCAL-VISUALIZATION dirancang menggunakan bahasa pemrograman R di RStudio, melibatkan berbagai package $\mathrm{R}$ (https://statcal.info/r-packages-in-statcal/) dalam membuat berbagai grafik. Jadi, jika Anda menginstall STATCAL-VISUALIZATION, berarti Anda juga akan menginstal $\mathrm{R}$ dan berbagai package $\mathrm{R}$. STATCAL-VISUALIZATION pertama dirancang pada Maret 2018 oleh Tim STATCAL.

STATCAL-VISUALIZATION dapat digunakan secara online dengan mengakses alamat https://gioprana.shinyapps.io/STATCAL-VISUALIZATION/ atau dapat digunakan secara offline dengan mendownload installernya di https://statcal.info/download-statcalvisualization/ (Gambar 1.1). Pada halaman website tersebut (Gambar 1.1) juga disisipkan video tutorial bagaimana cara menginstall STATCAL-VISUALIZATION. Ikuti tahapantahapan dalam menginstall STATCAL-VISUALIZATION di video tersebut. 


\section{Download STATCAL-VISUALIZATION}

Download STATCAL-VISUALIZATION (22/4/2018)

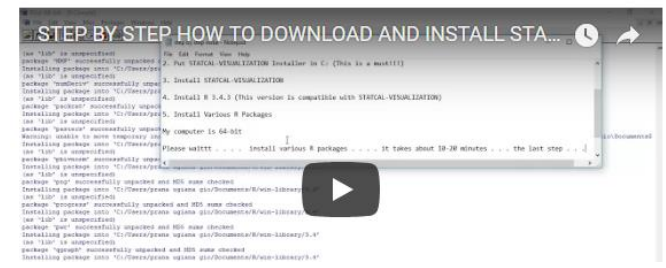

Gambar 1.1 Download STATCAL-VISUALIZATION

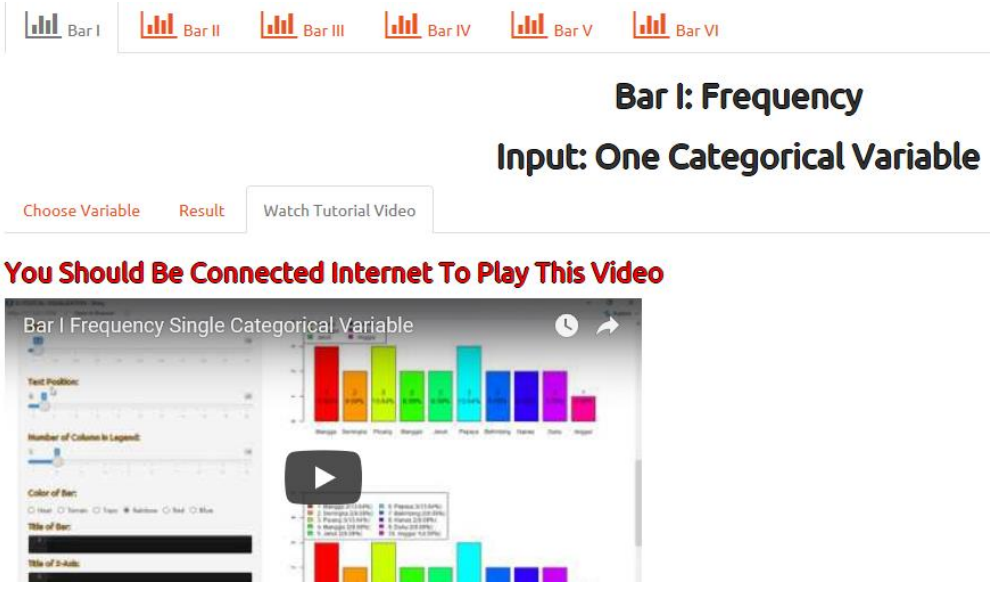

Gambar 1.2 Menu Tutorial Video

Di dalam STATCAL-VISUALIZATION disisipkan menu Watch Tutorial Video (Gambar 1.2). Di dalam menu Watch Tutorial video terdapat video tutorial yang dapat dijalankan dengan syarat terhubung internet. Video tutorial ini akan memandu Anda langkah-langkah membuat berbagai grafik. Informasi mengenai perkembangan STATCAL-VISUALIZATION dapat diakses pada alamat www.statcal.info, serta berbagai video dan modul pembelajaran STATCAL-VISUALIZATION dapat diakses pada alamat www.learningstatcal.com. Gambar 1.3 merupakan anggota-anggota dari tim STATCAL. 


\section{The STATCAL Team}

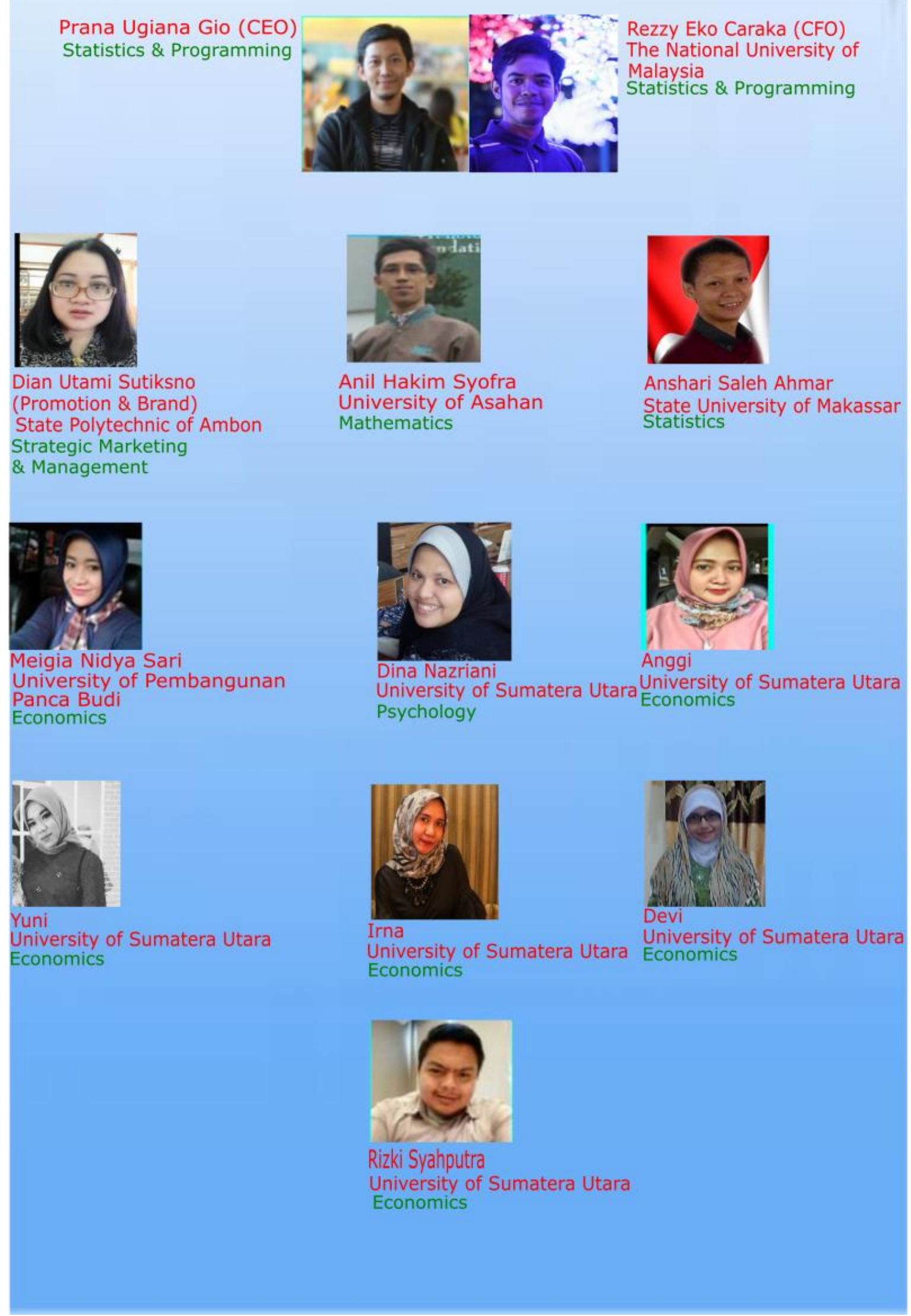

Gambar 1.3 Tim STATCAL 
Pengembangan STATCAL-VISUALIZATION terus dilakukan. Kedepannya STATCALVISUALIZATION akan menambah menu grafik mengenai principal component analysis (PCA), cluster analysis, neural network, dan sebagainya. Gambar 1.4 merupakan tampilan awal ketika program aplikasi STATCAL-VISUALIZATION dijalankan. Berdasarkan Gambar 1.4, terdapat berbagai menu, yakni menu Home, Input Numeric Data, Input Categorical Data, Bar, Line, Circle, Boxplot, Scatter Plot, Correlation Plot, Time Series, Descriptive dan Guidance. Pada menu Home berisi penjelasan singkat mengenai STATCAL-VISUALIZATION. Untuk menginput data numerik terletak pada bagian Input Numeric Data, sementara data kategori diinput pada bagian Input Categorical Data. Pada pembahasan selanjutnya akan dijelaskan sisa menu selanjutnya.

\section{STATCAL-VISUALIZATION}

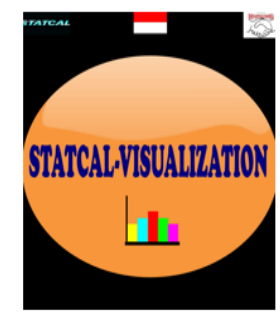

Developed by The STATCAL Team

Updated: 22-April-2018

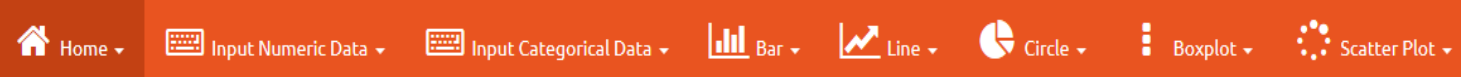

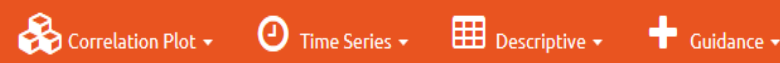

STATCAL-VISUALIZATION is an application program to create various graphs, such as bar, line, circle, boxplot, etc. STATCAL-VISUALIZATION is developed using $\mathrm{R}$ programming language in RStudio and uses various $\mathrm{R}$ packages to create various graph.

Gambar 1.4 Tampilan Awal Ketika STATCAL-VISUALIZATION Dijalankan 


\section{BAB 2}

\section{MENGINPUT DATA}

Pada pembahasan sebelumnya telah dibahas sekilas mengenai STATCAL-VISUALIZATION dan menu-menu yang tersedia di STATCAL-VISUALIZATION. Pada pembahasan kali ini akan dibahas mengenai persiapan data dan bagaimana cara menginput data di STATCALVISUALIZATION.

\subsection{Persiapan Data}

Misalkan diberikan data mengenai jenis kelamin, golongan darah, usia, berat badan, tinggi badan, nilai ujian matematika, fisika, kimia dan biologi dari 15 siswa (Gambar 2.1).

\begin{tabular}{|c|c|c|c|c|c|c|c|c|c|}
\hline E & $\mathrm{F}$ & G & $\mathrm{H}$ & I & J & K & L & $M$ & $\mathrm{~N}$ \\
\hline Nama & Jenis Kelamin & Golongan Darah & Usia & Berat Badan & Tinggi Badan & Matematika & Fisika & Kimia & Biologi \\
\hline $\mathrm{A}$ & 1 & 1 & 16 & 55.43 & 155.43 & 75 & 66 & 77 & 75 \\
\hline B & 2 & 2 & 15 & 58.64 & 158.64 & 75 & 64 & 76 & 58 \\
\hline $\mathrm{C}$ & 1 & 3 & 17 & 71.23 & 171.23 & 64 & 76 & 75 & 76 \\
\hline D & 1 & 4 & 15 & 63.34 & 163.34 & 72 & 56 & 56 & 65 \\
\hline$E$ & 2 & 1 & 17 & 61.23 & 161.23 & 65 & 76 & 74 & 55 \\
\hline $\mathrm{F}$ & 1 & 1 & 15 & 55.43 & 155.43 & 74 & 77 & 56 & 74 \\
\hline $\mathrm{G}$ & 1 & 2 & 17 & 58.53 & 158.53 & 66 & 64 & 44 & 87 \\
\hline $\mathrm{H}$ & 2 & 3 & 15 & 52.23 & 152.23 & 71 & 87 & 76 & 75 \\
\hline I & 2 & 4 & 16 & 61.12 & 161.12 & 53 & 76 & 74 & 65 \\
\hline $\mathrm{J}$ & 1 & 3 & 16 & 49.12 & 149.12 & 85 & 75 & 76 & 47 \\
\hline $\mathrm{K}$ & 1 & 1 & 15 & 54.32 & 154.32 & 81 & 68 & 76 & 87 \\
\hline $\mathrm{L}$ & 2 & 2 & 16 & 63.16 & 163.16 & 74 & 75 & 56 & 66 \\
\hline $\mathrm{M}$ & 1 & 3 & 15 & 64.32 & 164.32 & 59 & 62 & 74 & 74 \\
\hline $\mathrm{N}$ & 1 & 4 & 16 & 56.23 & 156.23 & 74 & 48 & 54 & 77 \\
\hline $\mathrm{O}$ & 2 & 1 & 17 & 62.12 & 162.12 & 65 & 75 & 76 & 64 \\
\hline & & & & & & & & & \\
\hline \multirow{2}{*}{ Angka } & \multicolumn{2}{|c|}{ Label } & & & & & & & \\
\hline & Jenis Kelamin & Golongan Darah & & & & & & & \\
\hline 1 & Laki-Laki & $\mathrm{A}$ & & & & & & & \\
\hline 2 & Perempuan & B & & & & & & & \\
\hline 3 & & $\mathrm{AB}$ & & & & & & & \\
\hline 4 & & $\mathrm{O}$ & & & & & & & \\
\hline
\end{tabular}

\section{Gambar 2.1 Data Diri dan Nilai Ujian dari 15 Siswa (Data Fiktif)}

Berdasarkan data pada Gambar 2.1, data dipersiapkan di Microsoft Excel. Alasan mengapa data dipersiapkan dalam Microsoft Excel adalah nantinya data tersebut dapat dipindahkan ke 
bagian input data di STATCAL-VISUALIZATION, yakni Input Categorical Data dan Input Numeric Data. Di samping itu STATCAL-VISUALIZATION belum dapat menyimpan data, sehingga data disimpan di Microsoft Excel. Terdapat 3 bagian warna, yakni:

$\Rightarrow$ Bagian warna kuning menyatakan untuk data berjenis kategori.

$\Rightarrow$ Bagian warna pink menyatakan untuk data berjenis numerik.

$\Rightarrow$ Sementara bagian warna hijau menyatakan label untuk data kategori, pada bagian warna kuning. Sebagai contoh, responden bernama $\mathrm{C}$ dengan jenis kelamin laki-laki (angka 1), golongan darah $\mathrm{AB}$ (angka 3).

\subsection{Menginput Data Kategori di STATCAL-VISUALIZATION}

Sekarang kita akan menginput data kategori pada Gambar 2.1 (bagian warna kuning) di STATCAL-VISUALIZATION. Pilih menu Input Categorical Data (Gambar 2.2), sehingga muncul tampilan wilayah input data kategori (Gambar 2.3).

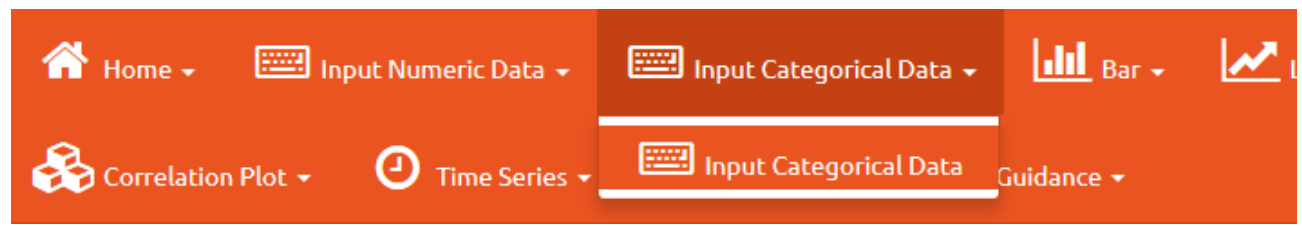

Gambar 2.2 Menu Input Categorical Data

Ada tiga bagian yang perlu diperhatikan, yakni bagian Categorical Data (Gambar 2.4), bagian penamaan variabel Name of Variable (Gambar 2.5) dan bagian Label (Gambar 2.6). Pada bagian Categorical Data (Gambar 2.4), bagian Set Number of Column menyatakan banyaknya variabel yang akan diinput. Diketahui jumlah variabel kategori sebanyak 2. Maka Anda dapat menginput angka 2 atau lebih besar dari 2 (misal 3, 4 ,5, 20, 100) pada di bagian Set Number of Column. Pada contoh kali ini, diinput angka 20. 


\section{Categorical Data}

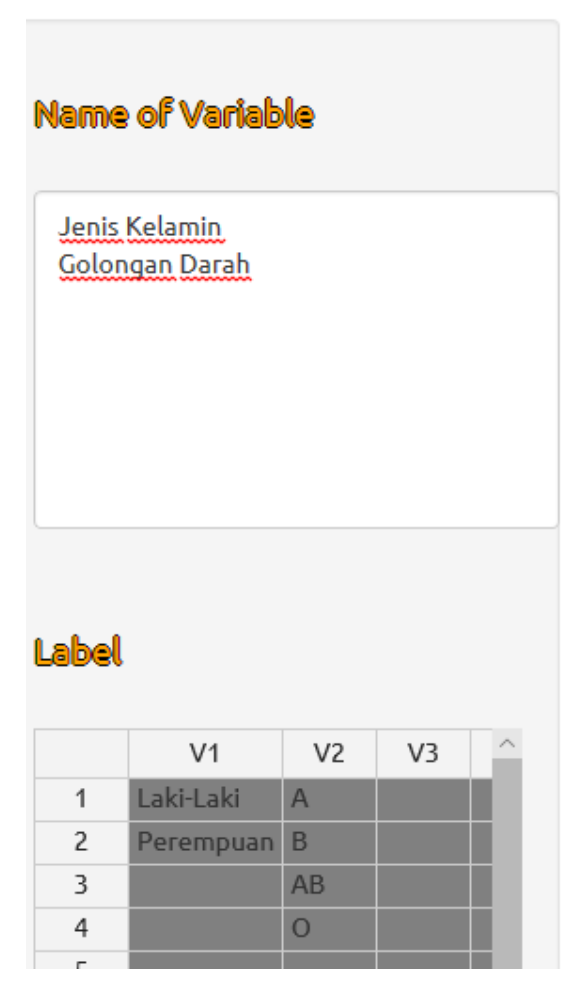

\section{Set Number of Column}

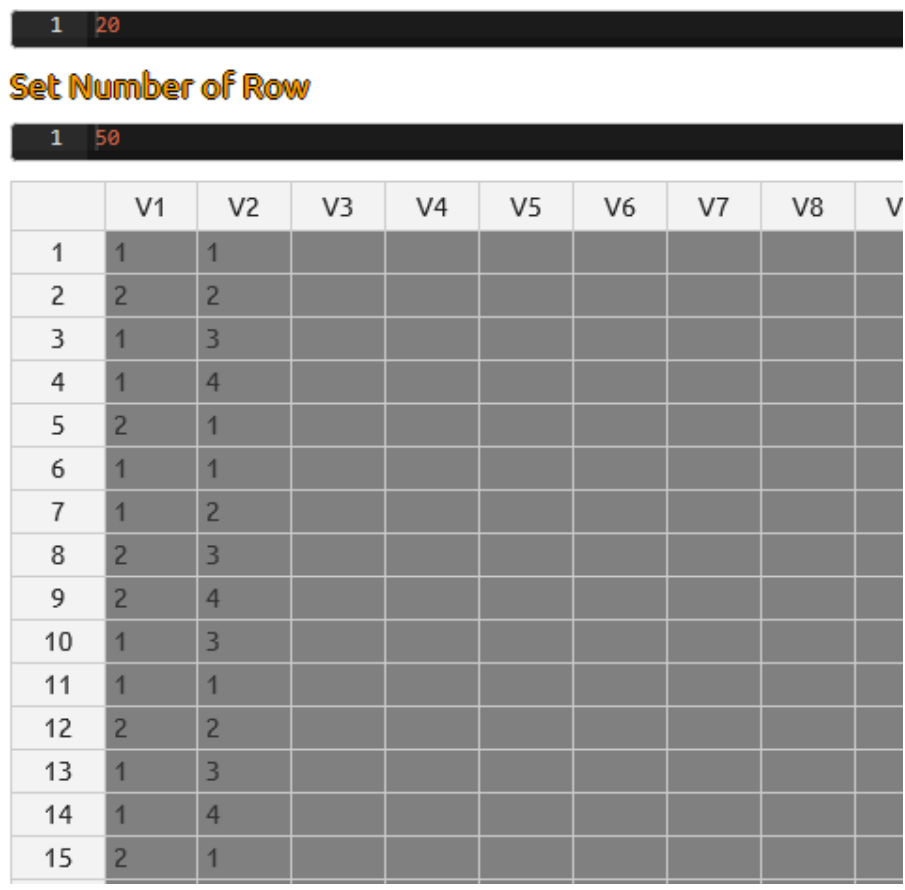

Gambar 2.3 Wilayah Input Data Kategori

Sementara bagian Set Number of Row menyatakan banyaknya pengamatan atau observasi.

Diketahui jumlah pengamatan sebanyak 15 pengamatan. Maka Anda dapat menginput angka 15 atau lebih besar dari 15 (misal 20, 25, 50, 1000) pada bagian Set Number of Row. Dalam contoh ini, Set Number of Row diisi dengan angka 50. Sekarang pindahkan data kategori jenis kelamin dan golongan darah (bagian warna kuning) ke Categorical Data (Gambar 2.4). Selanjutnya beri nama variabel pada bagian Name of Variable (Gambar 2.5). Nama Jenis Kelamin untuk kolom V1, sementara nama Golongan Darah untuk kolom V2. Terakhir adalah pemberian label untuk data kategori Gambar 2.4. Pindahkan label pada Gambar 2.1 (bagian warna hijau) ke bagian Label (Gambar 2.6). Data kategori yang telah diinput dapat dilihat pada bagian Your Categorical Data (Gambar 2.7). 


\section{Categorical Data}

Sett Number of Coluño

120

Selt Nunnober of Row

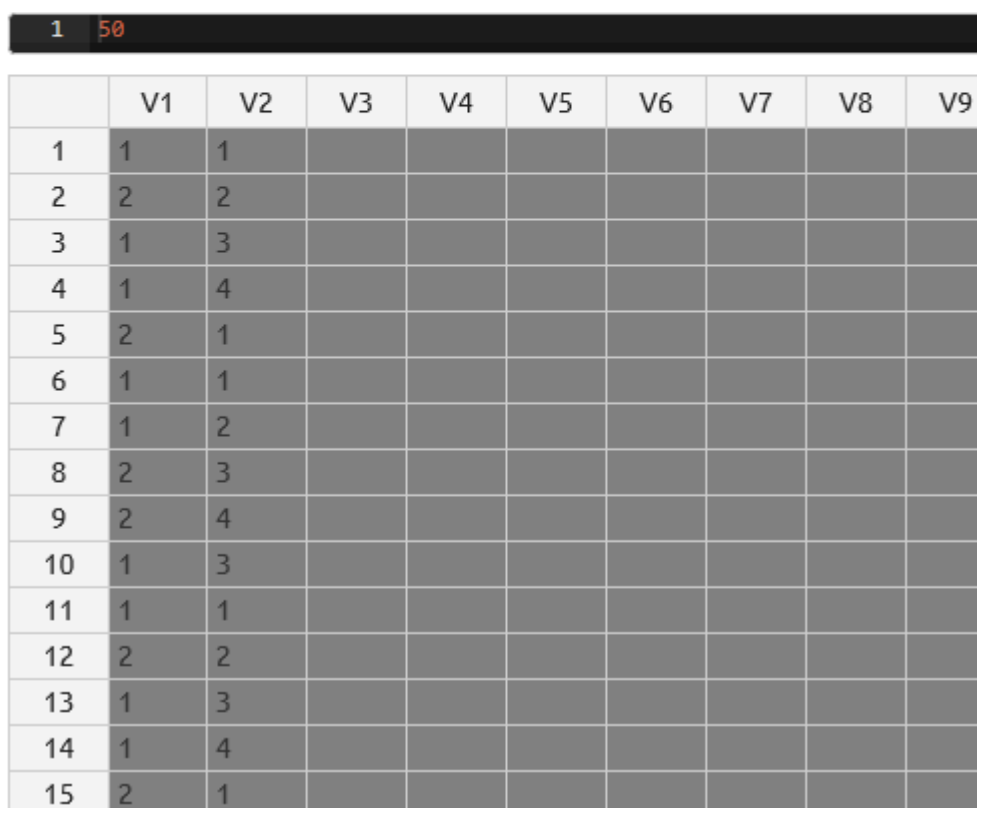

Gambar 2.4 Input Data Kategori

Nañe op Variable

Jenis Kelamin

Golongan Darah

Gambar 2.5 Penamaan Variabel

\section{Label}

\begin{tabular}{|c|l|l|l|}
\hline & \multicolumn{1}{|c|}{ V1 } & V2 & V3 \\
\hline 1 & Laki-Laki & A & \\
\hline 2 & Perempuan & B & \\
\hline 3 & & AB & \\
\hline 4 & & O & \\
\hline
\end{tabular}

Gambar 2.6 Pemberian Label 


\section{Your Categorical Data}

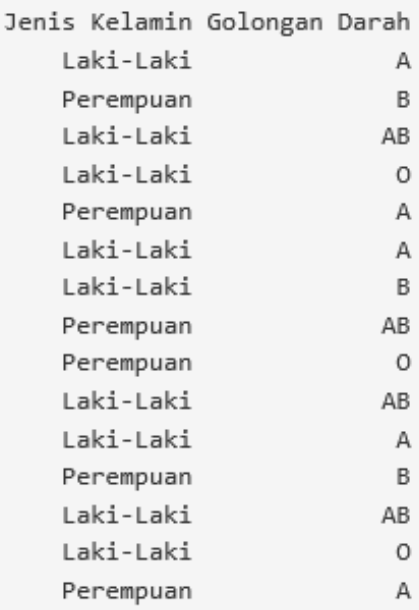

Gambar 2.7 Data Kategori Anda

\subsection{Menginput Data Numerik di STATCAL-VISUALIZATION}

Pada pembahasan sebelumnya telah dijelaskan langkah demi langkah menginput data kategori di STATCAL-VISUALIZATION. Sekarang kita akan menginput data numerik pada Gambar 2.1 (bagian warna pink) di STATCAL-VISUALIZATION, yakni bagian Input Numeric Data. Pilih menu Input Numeric Data (Gambar 2.8), sehingga muncul tampilan wilayah input data numerik (Gambar 2.9). Ada dua bagian yang perlu diperhatikan, yakni bagian Numeric Data (Gambar 2.10) dan bagian penamaan variabel Name of Variable (Gambar 2.11).

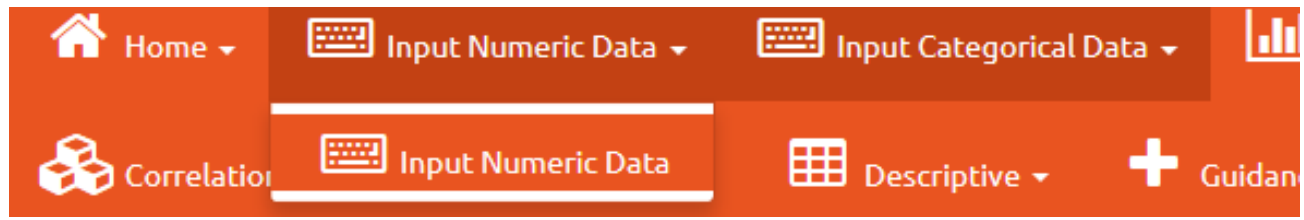

Gambar 2.8 Menu Input Numeric Data 


\section{Numeric Data}

\begin{tabular}{|c|c|c|c|c|c|c|c|c|c|}
\hline \multirow[b]{2}{*}{ Nañe o/ Variable } & \multicolumn{9}{|c|}{ Selt Nunnber of Coluñก } \\
\hline & \multicolumn{9}{|c|}{120} \\
\hline \multirow{18}{*}{$\begin{array}{l}\text { Usia } \\
\text { Berat Badan } \\
\text { Tinggi Badan } \\
\text { Matematika } \\
\text { Fisika } \\
\text { Kimia } \\
\text { Biologi }\end{array}$} & \multicolumn{9}{|c|}{ Sett Nuñber of Row } \\
\hline & \multicolumn{9}{|c|}{140} \\
\hline & & V1 & V2 & V3 & V4 & V5 & V6 & V7 & V8 \\
\hline & 1 & 16 & 55.43 & 155.43 & 75 & 66 & 77 & 75 & \\
\hline & 2 & 15 & 58.64 & 158.64 & 75 & 64 & 76 & 58 & \\
\hline & 3 & 17 & 71.23 & 171.23 & 64 & 76 & 75 & 76 & \\
\hline & 4 & 15 & 63.34 & 163.34 & 72 & 56 & 56 & 65 & \\
\hline & 5 & 17 & 61.23 & 161.23 & 65 & 76 & 74 & 55 & \\
\hline & 6 & 15 & 55.43 & 155.43 & 74 & 77 & 56 & 74 & \\
\hline & 7 & 17 & 58.53 & 158.53 & 66 & 64 & 44 & 87 & \\
\hline & 8 & 15 & 52.23 & 152.23 & 71 & 87 & 76 & 75 & \\
\hline & 9 & 16 & 61.12 & 161.12 & 53 & 76 & 74 & 65 & \\
\hline & 10 & 16 & 49.12 & 149.12 & 85 & 75 & 76 & 47 & \\
\hline & 11 & 15 & 54.32 & 154.32 & 81 & 68 & 76 & 87 & \\
\hline & 12 & 16 & 63.16 & 163.16 & 74 & 75 & 56 & 66 & \\
\hline & 13 & 15 & 64.32 & 164.32 & 59 & 62 & 74 & 74 & \\
\hline & 14 & 16 & 56.23 & 156.23 & 74 & 48 & 54 & 77 & \\
\hline & 15 & 17 & 62.12 & 162.12 & 65 & 75 & 76 & 64 & \\
\hline
\end{tabular}

\section{Gambar 2.9 Wilayah Input Data Numerik}

Pada bagian Numeric Data (Gambar 2.10), bagian Set Number of Column menyatakan banyaknya variabel yang akan diinput. Diketahui jumlah variabel numerik sebanyak 7. Maka Anda dapat menginput angka 7 atau lebih besar dari 7 (misal 3, 4 ,5, 20, 100) pada di bagian Set Number of Column. Pada contoh kali ini, diinput angka 20. Sementara bagian Set Number of Row menyatakan banyaknya pengamatan atau observasi. Diketahui jumlah pengamatan sebanyak 15 pengamatan. Maka Anda dapat menginput angka 15 atau lebih besar dari 15 (misal 20, 25, 50, 1000) pada bagian Set Number of Row. Dalam contoh ini, Set Number of Row diisi dengan angka 50. Sekarang pindahkan data numerik usia, berat badan, tinggi badan, matematika, fisika, kimia dan biologi (bagian warna kuning) ke Numeric Data (Gambar 2.10). Selanjutnya beri nama variabel pada bagian Name of Variable (Gambar 2.11). Data numerik yang telah diinput dapat dilihat pada bagian Your Numeric Data (Gambar 2.12). 


\section{Numeric Data}

Sett Number of Column

\begin{tabular}{|c|c|c|c|c|c|c|c|c|}
\hline \multicolumn{9}{|c|}{ Set Number of Row } \\
\hline \multicolumn{9}{|c|}{140} \\
\hline & V1 & V2 & V3 & V4 & V5 & v6 & v7 & v8 \\
\hline 1 & 16 & 55.43 & 155.43 & 75 & 66 & 77 & 75 & \\
\hline 2 & 15 & 58.64 & 158.64 & 75 & 64 & 76 & 58 & \\
\hline 3 & 17 & 71.23 & 171.23 & 64 & 76 & 75 & 76 & \\
\hline 4 & 15 & 63.34 & 163.34 & 72 & 56 & 56 & 65 & \\
\hline 5 & 17 & 61.23 & 161.23 & 65 & 76 & 74 & 55 & \\
\hline 6 & 15 & 55.43 & 155.43 & 74 & 77 & 56 & 74 & \\
\hline 7 & 17 & 58.53 & 158.53 & 66 & 64 & 44 & 87 & \\
\hline 8 & 15 & 52.23 & 152.23 & 71 & 87 & 76 & 75 & \\
\hline 9 & 16 & 61.12 & 161.12 & 53 & 76 & 74 & 65 & \\
\hline 10 & 16 & 49.12 & 149.12 & 85 & 75 & 76 & 47 & \\
\hline 11 & 15 & 54.32 & 154.32 & 81 & 68 & 76 & 87 & \\
\hline 12 & 16 & 63.16 & 163.16 & 74 & 75 & 56 & 66 & \\
\hline 13 & 15 & 64.32 & 164.32 & 59 & 62 & 74 & 74 & \\
\hline 14 & 16 & 56.23 & 156.23 & 74 & 48 & 54 & 77 & \\
\hline 15 & 17 & 62.12 & 162.12 & 65 & 75 & 76 & 64 & \\
\hline
\end{tabular}

Gambar 2.10 Input Data Numerik

Nañe of Variable
Usia
Berat Badan
Tinggi Badan
Matematika
Fisika
Kimia
Biologi

Gambar 2.11 Penamaan Variabel

\section{Your Numeric Data}

\begin{tabular}{|c|c|c|c|c|c|c|c|}
\hline & Usia Berat & Badan & Tinggi Badan & Matematika & Fisik & Kimia & Bio \\
\hline 1 & 16 & 55.43 & 155.43 & 75 & 66 & 77 & \\
\hline 2 & 15 & 58.64 & 158.64 & 75 & 64 & 76 & \\
\hline 3 & 17 & 71.23 & 171.23 & 64 & 76 & 75 & \\
\hline 4 & 15 & 63.34 & 163.34 & 72 & 56 & 56 & \\
\hline 5 & 17 & 61.23 & 161.23 & 65 & 76 & 74 & \\
\hline 6 & 15 & 55.43 & 155.43 & 74 & 77 & 56 & \\
\hline 7 & 17 & 58.53 & 158.53 & 66 & 64 & 44 & \\
\hline 8 & 15 & 52.23 & 152.23 & 71 & 87 & 76 & \\
\hline 9 & 16 & 61.12 & 161.12 & 53 & 76 & 74 & \\
\hline 10 & 16 & 49.12 & 149.12 & 85 & 75 & 76 & \\
\hline 11 & 15 & 54.32 & 154.32 & 81 & 68 & 76 & \\
\hline 12 & 16 & 63.16 & 163.16 & 74 & 75 & 56 & \\
\hline 13 & 15 & 64.32 & 164.32 & 59 & 62 & 74 & \\
\hline 14 & 16 & 56.23 & 156.23 & 74 & 48 & 54 & \\
\hline 15 & 17 & 62.12 & 162.12 & 65 & 75 & 76 & \\
\hline
\end{tabular}

Gambar 2.12 Data Numerik Anda 


\subsection{Data Kosong (Not Available / NA)}

Berikut akan diberi ilustrasi mengenai data kosong atau empty data. Perhatikan data pada Gambar 2.13. Pada Gambar 2.13, data pada baris ke-14, kolom V2 kosong. Pada bagian Your Numeric Data, data pada baris ke-14, kolom V2 berisi NA.

\section{Numeric Data}

Set Number of Columon

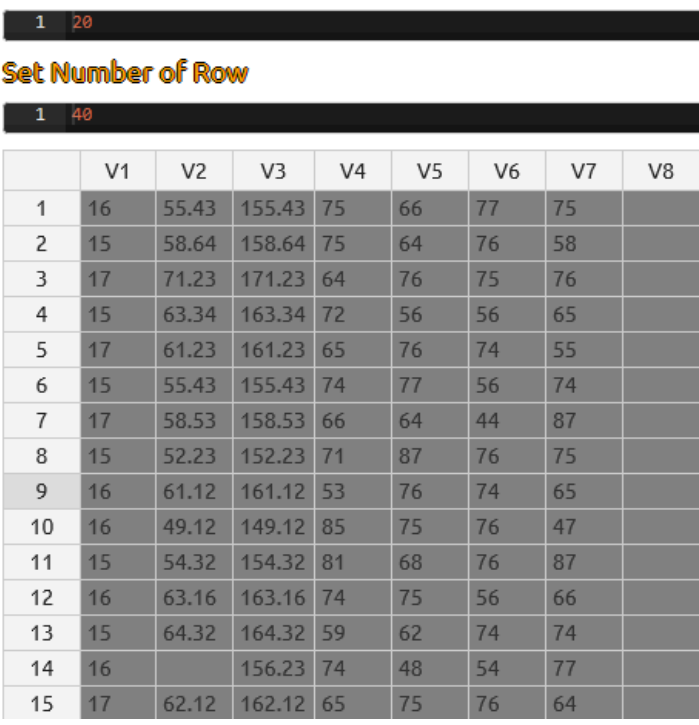

Gambar 2.13 Ilustrasi Data Kosong

\section{Your Numeric Data}

\begin{tabular}{lrrrrrrr} 
& \multicolumn{9}{c}{ Usia Berat Badan Tingi Badan } & Matematika Fisika Kimia Biologi \\
1 & 16 & 55.43 & 155.43 & 75 & 66 & 77 & 75 \\
2 & 15 & 58.64 & 158.64 & 75 & 64 & 76 & 58 \\
3 & 17 & 71.23 & 171.23 & 64 & 76 & 75 & 76 \\
4 & 15 & 63.34 & 163.34 & 72 & 56 & 56 & 65 \\
5 & 17 & 61.23 & 161.23 & 65 & 76 & 74 & 55 \\
6 & 15 & 55.43 & 155.43 & 74 & 77 & 56 & 74 \\
7 & 17 & 58.53 & 158.53 & 66 & 64 & 44 & 87 \\
8 & 15 & 52.23 & 152.23 & 71 & 87 & 76 & 75 \\
9 & 16 & 61.12 & 161.12 & 53 & 76 & 74 & 65 \\
10 & 16 & 49.12 & 149.12 & 85 & 75 & 76 & 47 \\
11 & 15 & 54.32 & 154.32 & 81 & 68 & 76 & 87 \\
12 & 16 & 63.16 & 163.16 & 74 & 75 & 56 & 66 \\
13 & 15 & 64.32 & 164.32 & 59 & 62 & 74 & 74 \\
14 & 16 & NA & 156.23 & 74 & 48 & 54 & 77 \\
15 & 17 & 62.12 & 162.12 & 65 & 75 & 76 & 64
\end{tabular}

Gambar 2.14 Data Kosong Diisi dengan NA (Not Available) 
Contoh lain lagi pada Gambar 2.15, data pada baris ke-12, kolom V3 diisi dengan huruf "A", data pada baris ke-12, kolom V4 diisi dengan kata "saya" dan data pada baris ke-14, kolom V3 diisi dengan 152,34 (menggunakan koma, bukan titik). Hasilnya diperlihatkan pada Gambar 2.16, terganti dengan NA.

\section{Numeric Data}

\begin{tabular}{|c|c|c|c|c|c|c|c|c|}
\hline \multicolumn{9}{|c|}{ Sett Nunnber of Row } \\
\hline \multicolumn{9}{|c|}{140} \\
\hline & V1 & V2 & V3 & V4 & v5 & V6 & v7 & V8 \\
\hline 1 & 16 & 55.43 & 155.43 & 75 & 66 & 77 & 75 & \\
\hline 2 & 15 & 58.64 & 158.64 & 75 & 64 & 76 & 58 & \\
\hline 3 & 17 & 71.23 & 171.23 & 64 & 76 & 75 & 76 & \\
\hline 4 & 15 & 63.34 & 163.34 & 72 & 56 & 56 & 65 & \\
\hline 5 & 17 & 61.23 & 161.23 & 65 & 76 & 74 & 55 & \\
\hline 6 & 15 & 55.43 & 155.43 & 74 & 77 & 56 & 74 & \\
\hline 7 & 17 & 58.53 & 158.53 & 66 & 64 & 44 & 87 & \\
\hline 8 & 15 & 52.23 & 152.23 & 71 & 87 & 76 & 75 & \\
\hline 9 & 16 & 61.12 & 161.12 & 53 & 76 & 74 & 65 & \\
\hline 10 & 16 & 49.12 & 149.12 & 85 & 75 & 76 & 47 & \\
\hline 11 & 15 & 54.32 & 154.32 & 81 & 68 & 76 & 87 & \\
\hline 12 & 16 & 63.16 & $A$ & saya & 75 & 56 & 66 & \\
\hline 13 & 15 & 64.32 & 164.32 & 59 & 62 & 74 & 74 & \\
\hline 14 & 16 & & 152,34 & 74 & 48 & 54 & 77 & \\
\hline 15 & 17 & 62.12 & 162.12 & & 75 & 76 & 64 & \\
\hline
\end{tabular}

Gambar 2.15 Ilustrasi Data Kosong, Huruf dan Koma pada Input Data Numerik

\section{Your Numeric Data}

\begin{tabular}{rrrrrrr} 
Usia Berat Badan & \multicolumn{5}{c}{ Tinggi Badan Matematika Fisika Kimia Biologi } \\
16 & 55.43 & 155.43 & 75 & 66 & 77 & 75 \\
15 & 58.64 & 158.64 & 75 & 64 & 76 & 58 \\
17 & 71.23 & 171.23 & 64 & 76 & 75 & 76 \\
15 & 63.34 & 163.34 & 72 & 56 & 56 & 65 \\
17 & 61.23 & 161.23 & 65 & 76 & 74 & 55 \\
15 & 55.43 & 155.43 & 74 & 77 & 56 & 74 \\
17 & 58.53 & 158.53 & 66 & 64 & 44 & 87 \\
15 & 52.23 & 152.23 & 71 & 87 & 76 & 75 \\
16 & 61.12 & 161.12 & 53 & 76 & 74 & 65 \\
16 & 49.12 & 149.12 & 85 & 75 & 76 & 47 \\
15 & 54.32 & 154.32 & 81 & 68 & 76 & 87 \\
16 & 63.16 & NA & NA & 75 & 56 & 66 \\
15 & 64.32 & 164.32 & 59 & 62 & 74 & 74 \\
16 & NA & NA & 74 & 48 & 54 & 77 \\
17 & 62.12 & 162.12 & 65 & 75 & 76 & 64
\end{tabular}

Gambar 2.16 Data Numerik Anda 


\section{BAB 3}

\section{MEMBUAT GRAFIK BATANG}

Pada pemaparan sebelumnya telah dijelaskan langkah demi langkah menginput data kategori dan numerik di STATCAL-VISUALIZATION. Kali ini akan diberikan beberapa contoh membuat grafik batang di STATCAL-VISUALIZATION. Menu Bar untuk membuat berbagai grafik batang (Gambar 3.1). Dalam menu Bar, terdapat pilihan Frequency dan Mean and Standard Deviation. Pilihan Frequency untuk membuat berbagai grafik batang frekuensi, sementara pilihan Mean and Standard Deviation untuk membuat grafik batang rata-rata dan standar deviasi. Pada pilihan Frequency, input berupa variabel kategori, sementara pada pilihan Mean and Standard Deviation, input dapat berupa variabel numerik atau kombinasi dari variabel numerik dan variabel kategori.

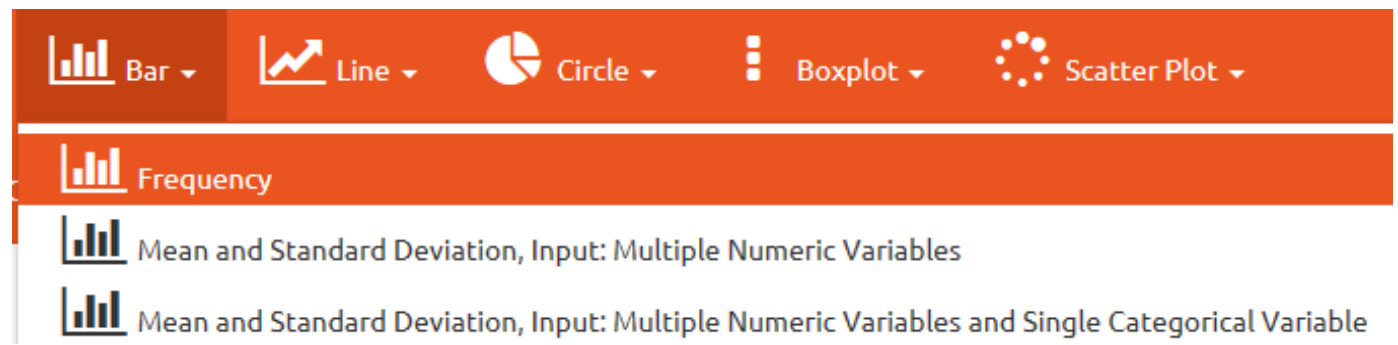

Gambar 3.1 Menu Grafik Batang

\subsection{Membuat Grafik Batang Frekuensi (Input: Satu Variabel Kategori)}

Berdasarkan data kategori yang telah diinput pada Gambar 2.3, akan dibuat grafik batang frekuensi berdasarkan variabel golongan darah, seperti pada Gambar 3.2. Diketahui terdapat 5 (33,33\%) siswa dengan golongan darah A, 3 (20\%) dengan golongan darah B, 4 (26,67\%) dengan golongan darah AB dan 3 (20\%) dengan golongan darah O. 

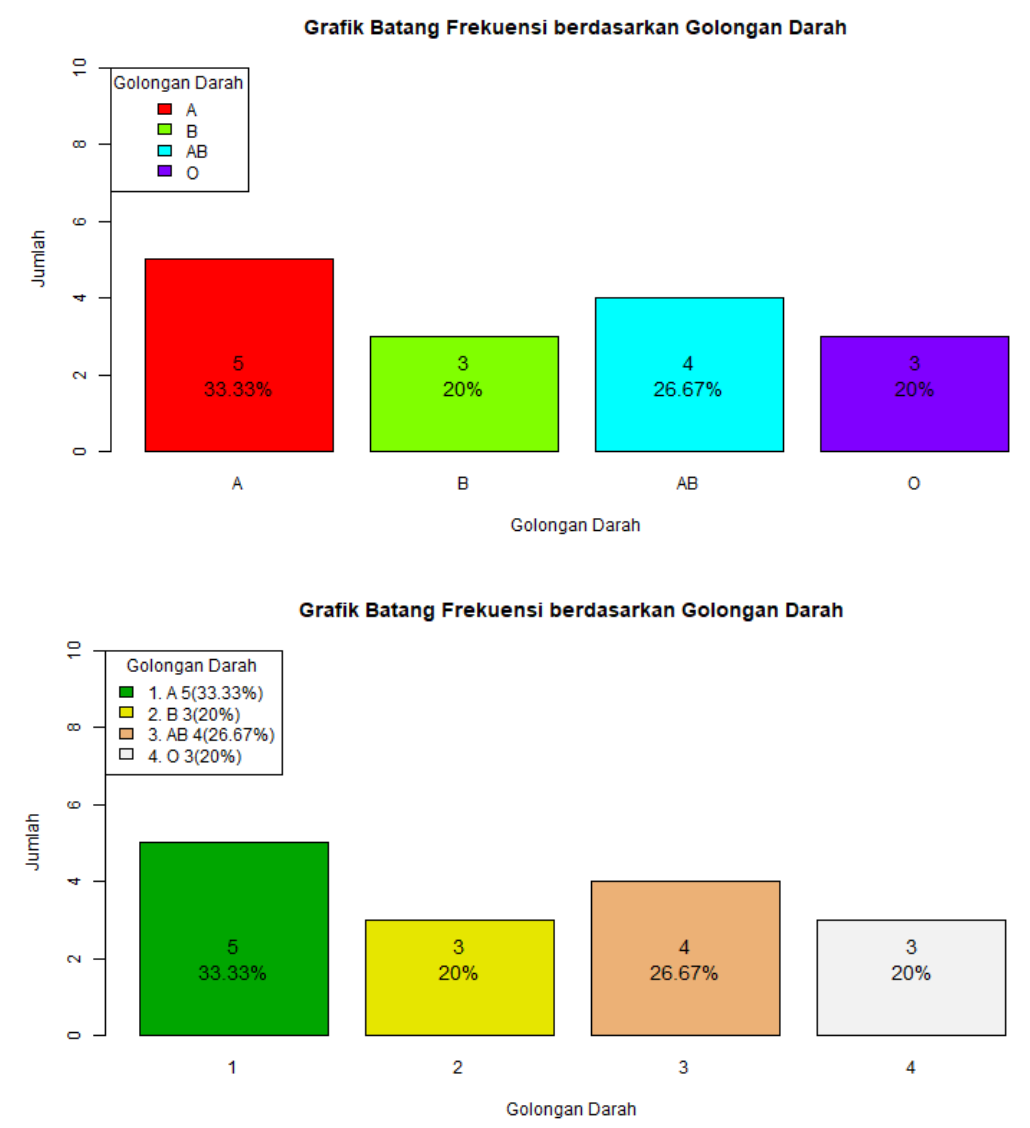

\section{Gambar 3.2 Grafik Batang Frekuensi berdasarkan Golongan Darah}

Pertama, pilih Bar => Frequency $($ Gambar 3.1). Kemudian pilih Input: One Variable => Bar I (Gambar 3.3). Sekarang Anda berada pada bagian Choose Variable. Pada bagian Choose Variable ini, Anda dapat memindahkan satu variabel kategori (Single Choice) ke bagian kotak sebelah kanan. Pada contoh Gambar 3.3, variabel golongan darah dipindahkan ke kotak sebelah kanan. Selanjutnya hasil dari grafik batang frekuensi dapat dilihat pada bagian Result (Gambar 3.4). Pada bagian Result, dapat dilakukan berbagai pengaturan dari grafik batang frekuensi, seperti menampilkan frekuensi atau persentase, warna batang, posisi legend, judul, dan sebagainya (Gambar 3.5). Di samping itu, terdapat menu Watch Tutorial Video. Di dalam menu Watch Tutorial Video disisipkan video yang dapat diputar dengan syarat terkoneksi internet. Video tersebut akan memandu Anda langkah-langkah membuat grafik batang frekuensi terkait. 


$$
\begin{aligned}
& \text { Wlll Input: One Variable } \quad \text { 山lll Input: Two Variables } \quad \text { 山ll Input: More Than Two Variables }
\end{aligned}
$$

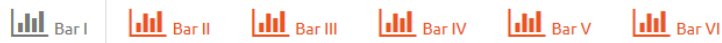

Bar l: Frequency

$$
\text { Input: One Categorical Variable }
$$

Choose Variable Result Watch Tutorial Video

Choose Cattegorical Variable (Single Choice)

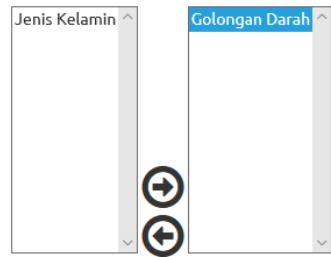

Gambar 3.3 Bar I: Frequency

Input: One Categorical Data

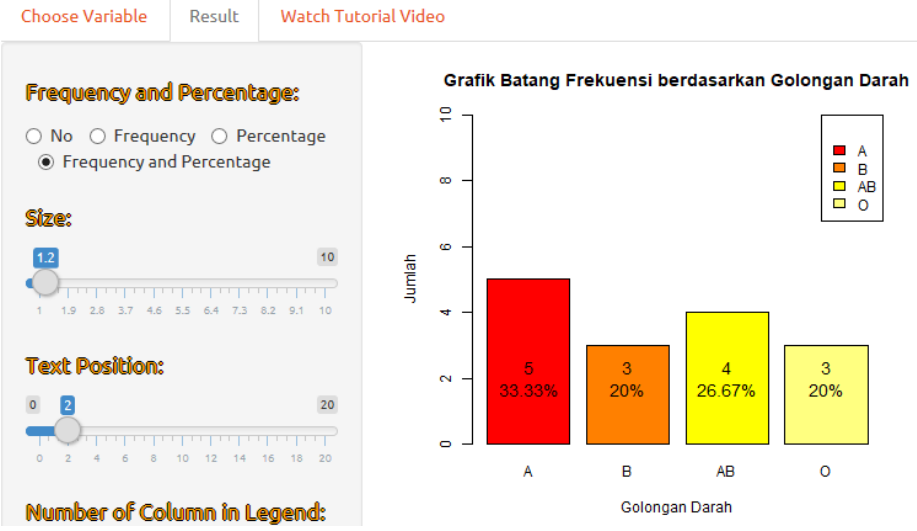

Gambar 3.4 Result
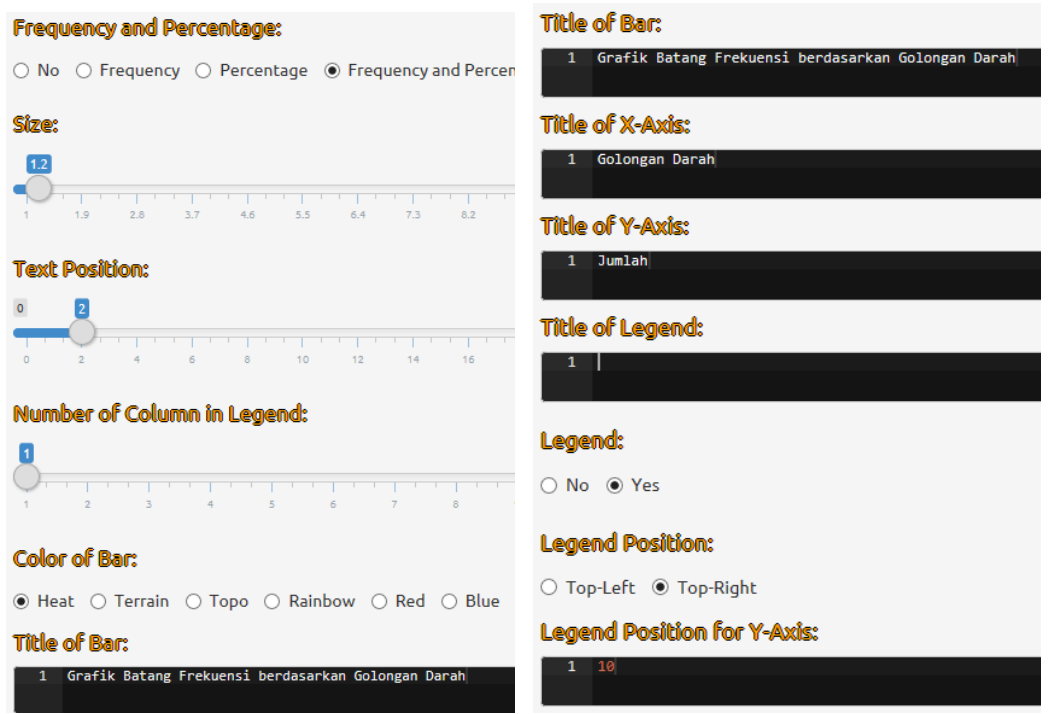

Gambar 3.5 Berbagai Pengaturan Grafik Batang Frekuensi di Bagian Result 
Anda juga dapat membuat grafik batang frekuensi dengan tampilan yang sedikit berbeda, seperti pada Gambar 3.6 (menu Bar III) sampai Gambar 3.7 (menu Bar V).

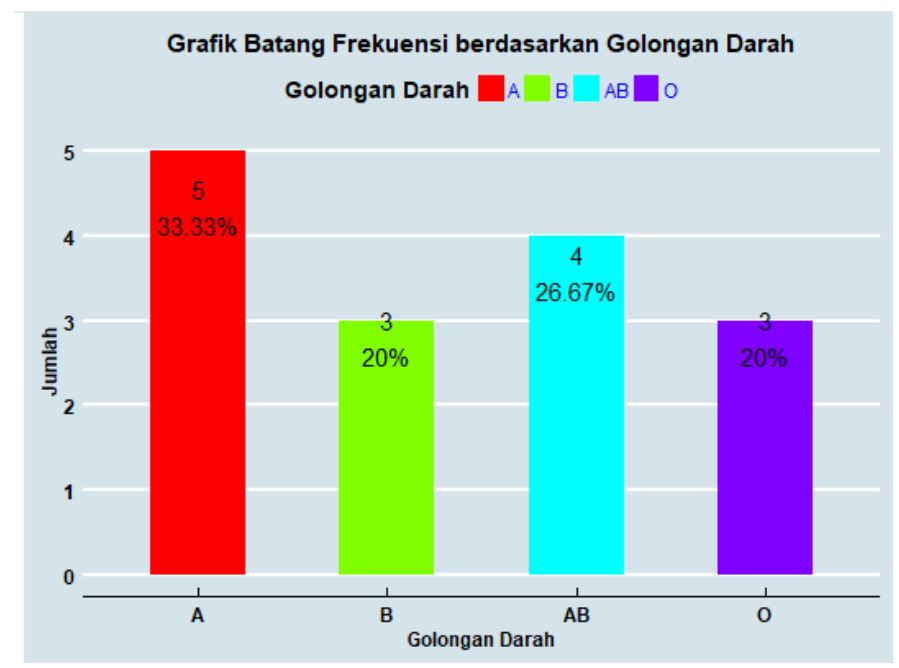

Gambar 3.6 Grafik Batang Frekuensi (Bar III)

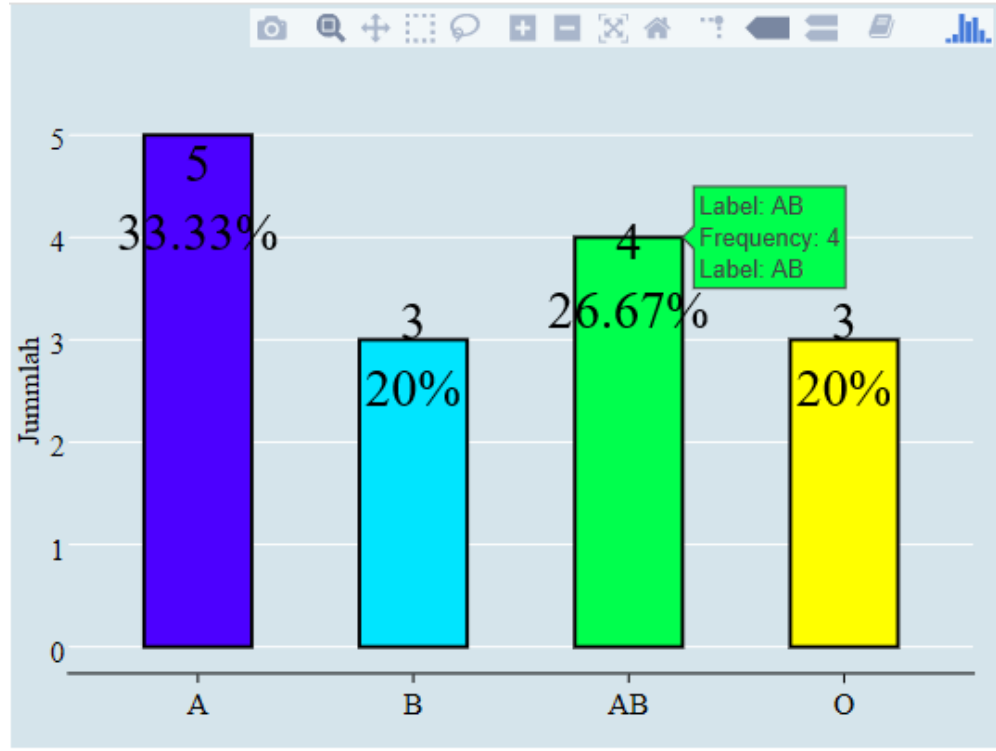

Gambar 3.7 Grafik Batang Frekuensi (Bar V)

Misalkan diberikan data distribusi frekuensi berdasarkan golongan darah seperti pada Tabel 3.1. Anda tetap dapat membuat grafik batang frekuensi seperti pada Gambar 3.2 dengan 
menggunakan menu Bar II, Bar IV dan Bar VI (Gambar 3.8). Masukkan data pada Tabel 3.1 ke kotak Label dan Frequency (Gambar 3.8). Hasilnya dapat dilihat pada bagian Result.

Tabel 3.1 Distribusi Frekuensi berdasarkan Golongan Darah

\begin{tabular}{|c|c|}
\hline Golongan Darah & Frekuensi \\
\hline $\mathrm{A}$ & 5 \\
\hline $\mathrm{B}$ & 3 \\
\hline $\mathrm{AB}$ & 4 \\
\hline $\mathrm{O}$ & 3 \\
\hline
\end{tabular}

\begin{tabular}{|c|c|c|c|}
\hline 山ll Inp & iable & Џلl Input: Two Variables & Џلl Input: More Than Two Variables \\
\hline I & 山ll Bar॥ & Lلll Bar III & 山ll BarV \\
\hline
\end{tabular}

\section{Bar II: Frequency \\ Input: Label and Frequency}

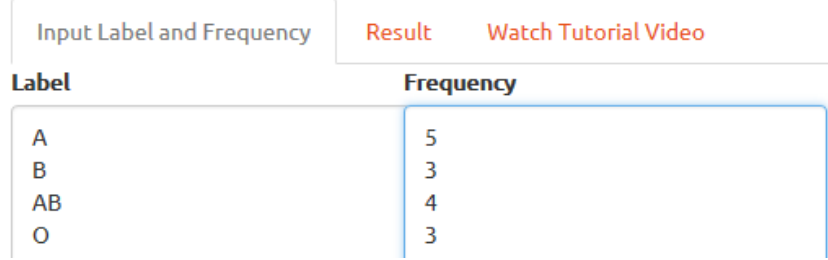

Gambar 3.8 Bar II: Frequency

Input: Label and Frequency

\subsection{Membuat Grafik Batang Frekuensi (Input: Dua Variabel Kategori)}

Pada pembahasan sebelumnya, grafik batang frekuensi hanya melibatkan satu variabel kategori. Sementara pada bagian ini, pembuatan grafik batang frekuensi melibatkan dua variabel kategori. Perhatikan Gambar 3.9 dan Gambar 3.10. Berdasarkan grafik batang frekuensi pada Gambar 3.9 dan Gambar 3.10, diketahui dari 5 siswa dengan golongan darah A, $3(60 \%)$ di antaranya dengan jenis kelamin laki-laki, sementara $2(40 \%)$ perempuan. 


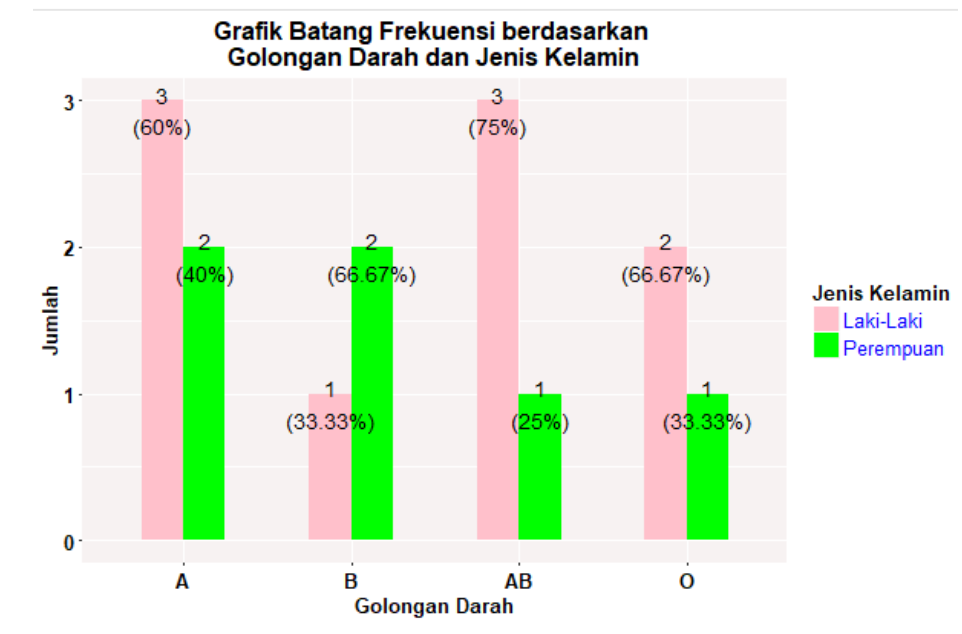

Gambar 3.9 Grafik Batang Frekuensi berdasarkan Golongan Darah dan Jenis Kelamin

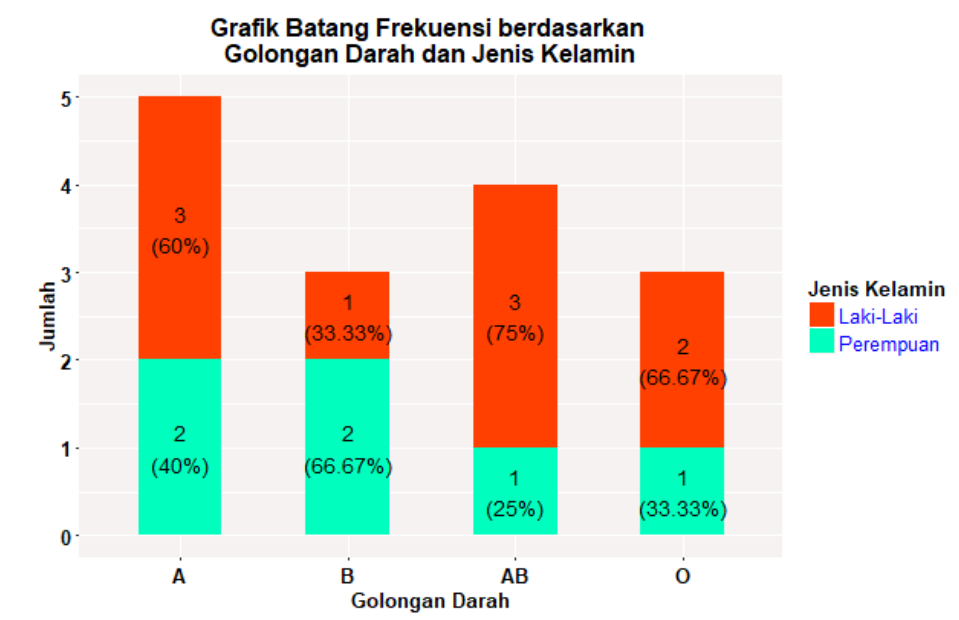

Gambar 3.10 Grafik Batang Frekuensi berdasarkan Golongan Darah dan Jenis Kelamin

Untuk membuat grafik batang frekuensi seperti pada Gambar 3.9 dan Gambar 3.10, pilih Bar => Frequency (Gambar 3.1). Kemudian pilih Input: Two Variables => Bar I (Gambar 3.11). Selanjutnya, pindahkan variabel golongan darah ke kotak sebelah kanan pada Choose Categorical Variable (Single Choice) (X-Axis), variabel jenis kelamin juga dipindahkan ke kotak sebelah kanan pada Choose Categorical Variable (Single Choice) (Y-Axis). Hasilnya dapat dilihat pada bagian Result. Berbagai pengaturan grafik batang frekuensi dapat dilakukan pada bagian Result, mulai dari warna batang, menampilkan frekuensi, judul, dan sebagainya (Gambar 3.12). Di samping itu, terdapat menu Watch Tutorial Video. Di dalam 
menu Watch Tutorial Video disisipkan video yang dapat diputar dengan syarat terkoneksi internet. Video tersebut akan memandu Anda langkah-langkah membuat grafik batang frekuensi terkait.

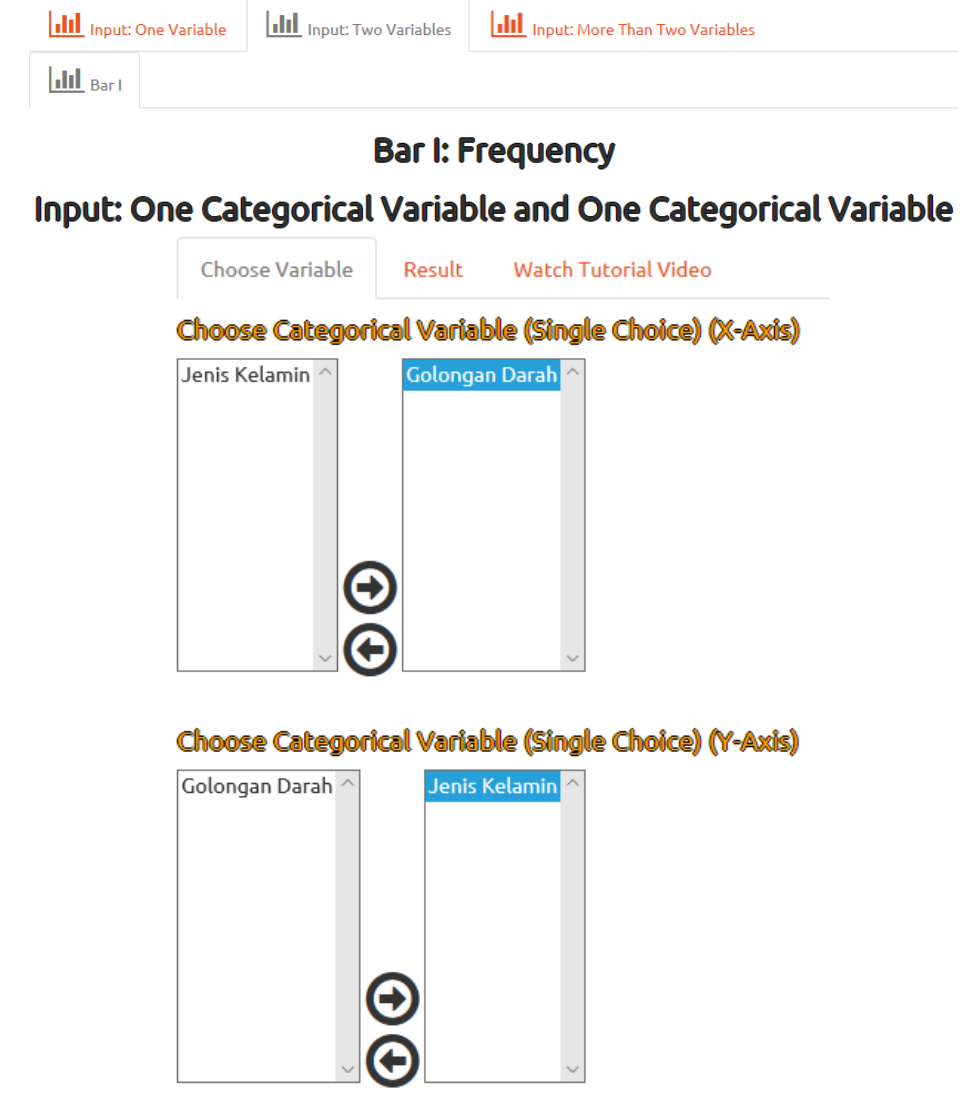

Gambar 3.11 Bar I: Frequency Input: One Categorical Variable and One Categorical Variable
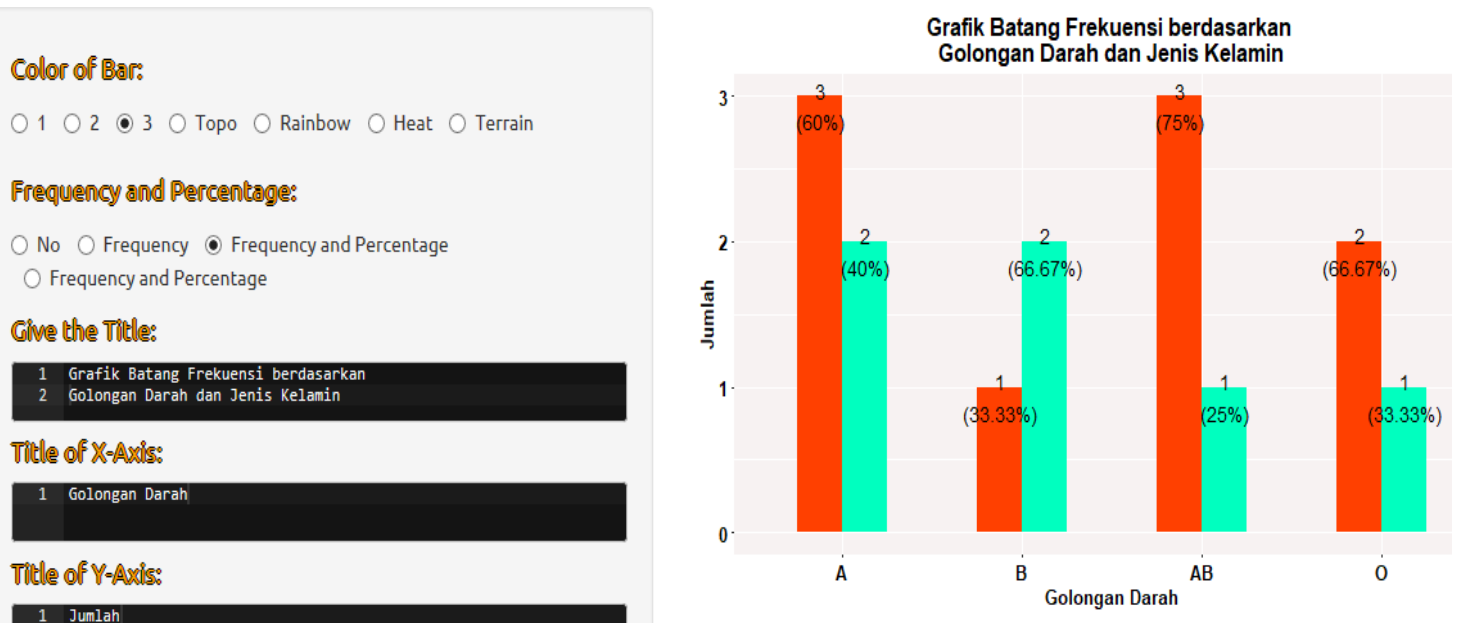

Gambar 3.12 Berbagai Pengaturan Grafik Batang Frekuensi 


\subsection{Membuat Grafik Batang Frekuensi (Input: Lebih dari Dua Variabel Kategori)}

Misalkan Tabel 3.2 merupakan data jawaban 10 responden berdasarkan 5 pertanyaan. Berdasarkan data pada Tabel 3.2, misalkan angka 1 menyatakan sangat tidak setuju (STS), angka 2 menyatakan tidak setuju (TS), angka 3 menyatakan kurang setuju (KS), angka 4 menyatakan setuju (S), dan angka 5 menyatakan sangat setuju (STS).

\section{Tabel 3.2 Data Jawaban 10 Responden berdasarkan 5 Pertanyaan}

\begin{tabular}{|c|c|c|c|c|c|}
\hline Nama & P1 & P2 & P3 & P4 & P5 \\
\hline A & 1 & 3 & 4 & 5 & 4 \\
\hline B & 4 & 4 & 5 & 5 & 4 \\
\hline C & 4 & 4 & 5 & 5 & 4 \\
\hline D & 3 & 3 & 4 & 5 & 4 \\
\hline E & 2 & 4 & 5 & 5 & 4 \\
\hline F & 3 & 4 & 4 & 5 & 4 \\
\hline G & 5 & 4 & 3 & 5 & 4 \\
\hline H & 4 & 4 & 2 & 5 & 4 \\
\hline I & 3 & 3 & 3 & 5 & 4 \\
\hline J & 1 & 3 & 4 & 5 & 4 \\
\hline
\end{tabular}

Berdasarkan data pada Tabel 3.2, dibuat grafik batang frekuensi (Gambar 3.13), distribusi frekuensi dan persentase (Gambar 3.14), dan bantuan interpretasi (Gambar 3.15). Pilih Bar => Frekuensi (Gambar 3.1). Kemudian pilih Input: More Than Two Variables => Bar I (Gambar 3.16). Selanjutnya pindahkan data jawaban responden, isi label dan value (Gambar 3.16). Hasil dari grafik batang frekuensi dapat dilihat pada bagian Result.

Pada bagian Result, berbagai pengaturan grafik batang frekuensi, seperti pengaturan warna batang, ukuran teks, judul, dan sebagainya dapat dilakukan. Di samping itu, pada bagian Watch Tutorial Video, disisipkan video tutorial yang memandu Anda membuat grafik batang frekuensi terkait. 


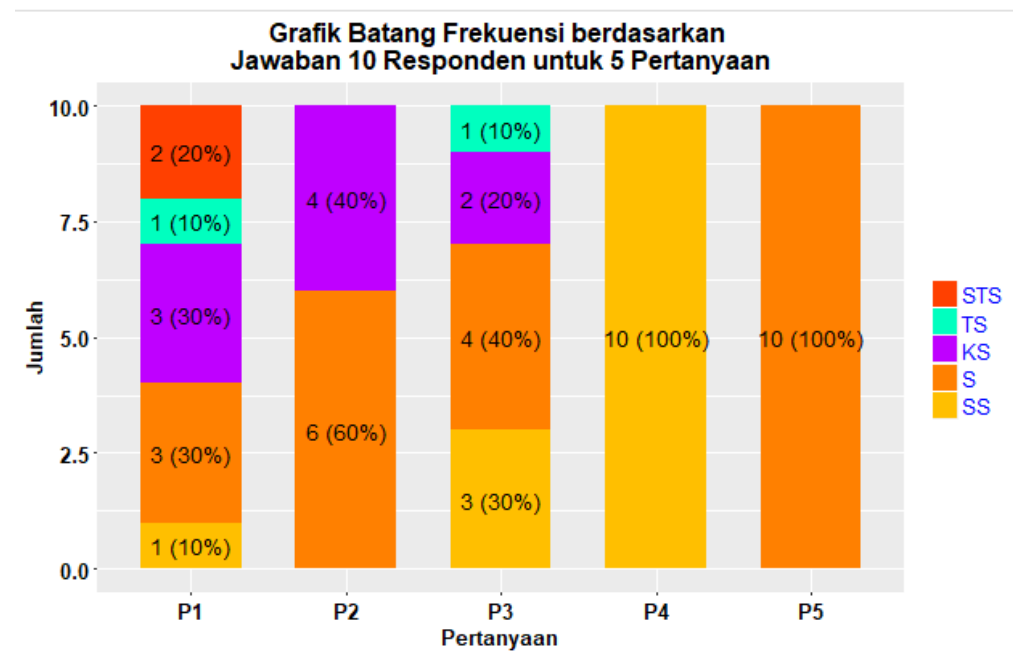

\section{Gambar 3.13 Grafik Batang Frekuensi berdasarkan Jawaban 10 Responden untuk 5 Pertanyaan}

\begin{tabular}{|c|c|c|c|c|c|c|c|c|c|c|c|c|}
\hline & STS & STS & TS & TS & KS & $\mathbf{K S}$ & $\mathbf{S}$ & $\mathbf{S}$ & SS & SS & $\begin{array}{r}\text { Total of } \\
\text { Frequency }\end{array}$ & $\begin{array}{l}\text { Total of } \\
\text { Percentage }\end{array}$ \\
\hline P1 & 2 & 20 & 1 & 10 & 3 & 30 & 3 & 30 & 1 & 10 & 10 & $100 \%$ \\
\hline P2 & 0 & 0 & 0 & 0 & 4 & 40 & 6 & 60 & 0 & 0 & 10 & $100 \%$ \\
\hline P3 & 0 & 0 & 1 & 10 & 2 & 20 & 4 & 40 & 3 & 30 & 10 & $100 \%$ \\
\hline P4 & 0 & 0 & 0 & 0 & 0 & 0 & 0 & 0 & 10 & 100 & 10 & $100 \%$ \\
\hline P5 & 0 & 0 & 0 & 0 & 0 & 0 & 10 & 100 & 0 & 0 & 10 & $100 \%$ \\
\hline
\end{tabular}

Gambar 3.14 Distribusi Frekuensi dan Persentase berdasarkan Jawaban 10 Responden untuk 5 Pertanyaan

\footnotetext{
Untuk pertanyaan ke-1 (P1), terdapat 2 (20.00\%) responden menjawab STS, responden me njawab TS sebanyak 1 (10.00\%), responden menjawab KS sebanyak 3 (30.00\%), responden menjawab S sebanyak 3 (30.00\%) dan responden menjawab SS sebanyak 1 (10.00\%)

Untuk pertanyaan ke-2 (P2), terdapat 4 (40.00\%) responden menjawab KS dan responden menjawab S sebanyak 6 (60.00\%)

Untuk pertanyaan ke-3 (P3), terdapat 1 (10.00\%) responden menjawab TS, responden men jawab KS sebanyak 2 (20.00\%), responden menjawab S sebanyak 4 (40.00\%) dan responden menjawab SS sebanyak 3 (30.00\%)

Untuk pertanyaan ke-4 (P4), seluruh responden menjawab SS.

Untuk pertanyaan ke-5 (P5), seluruh responden menjawab S.
}

Gambar 3.15 Bantuan Interpretasi 


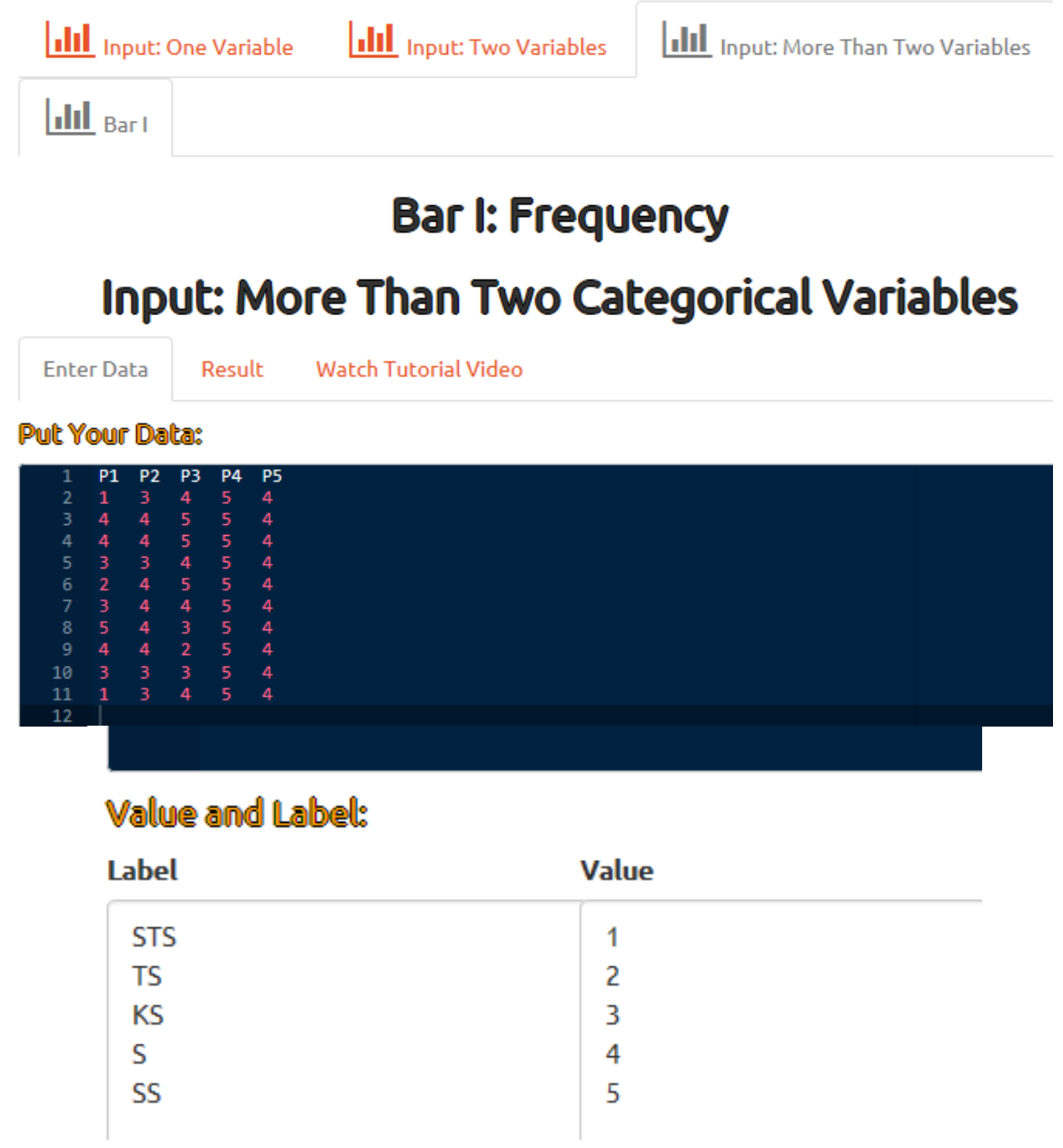

Gambar 3.16 Bar I: Frequency

Input: More Than Two Categorical Variables

\subsection{Membuat Grafik Batang Rata-Rata (Input: Lebih dari Satu Variabel Numerik)}

Pada pembahasan sebelumnya telah dibahas bagaimana membuat berbagai grafik batang frekuensi dengan satu, dua atau lebih variabel kategori. Sekarang akan dibahas bagaimana membuat grafik batang rata-rata. Untuk membuat grafik batang rata-rata tentunya melibatkan variabel numerik. Dari data pada Gambar 2.9, disajikan grafik batang rata-rata berdasarkan nilai ujian matematika, fisika, kimia dan biologi, seperti pada Gambar 3.17. Diketahui ratarata ujian matematika adalah 70,2, dengan standar deviasi 8,28 , rata-rata ujian fisika adalah 69,67, dengan standar deviasi 9,84, dan seterusnya. 

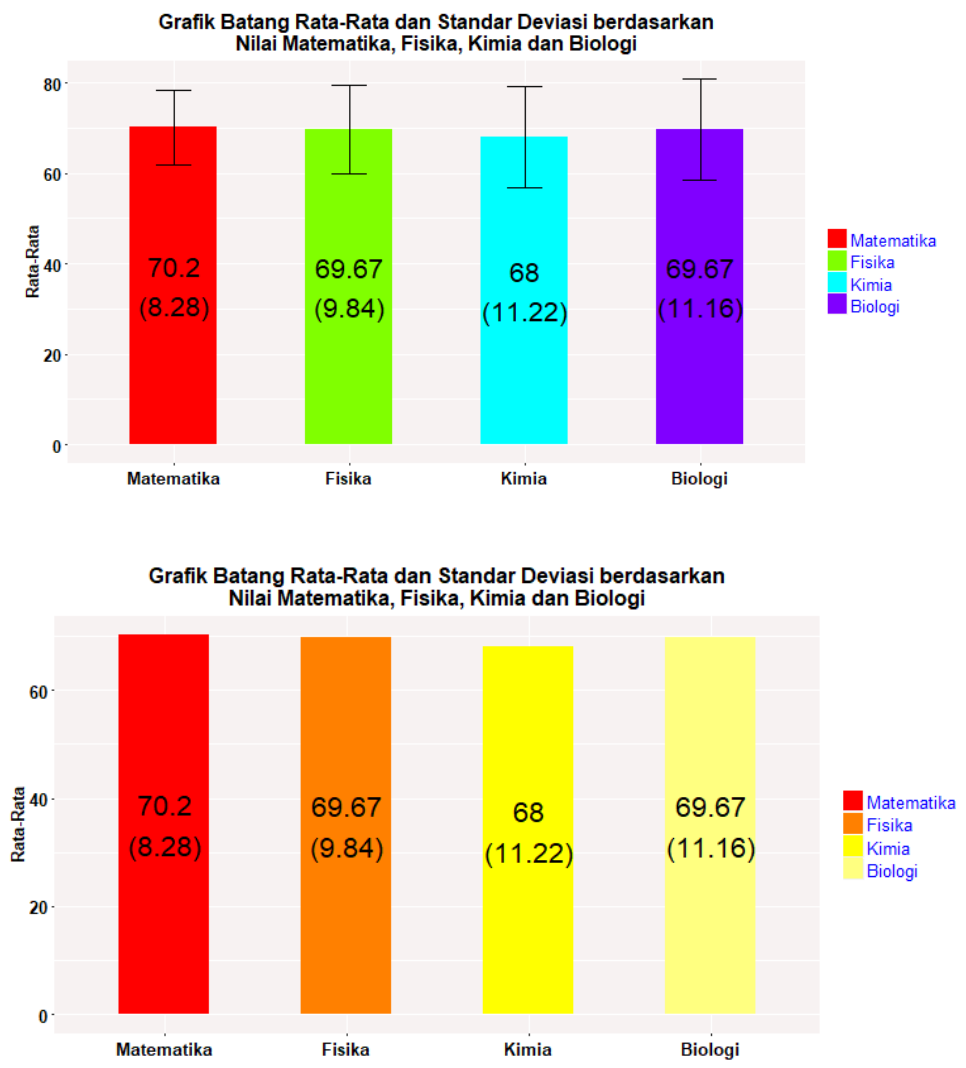

Gambar 3.17 Grafik Batang Rata-Rata dan Standar Deviasi berdasarkan Nilai Matematika, Fisika, Kimia dan Biologi

Berikut tahapan untuk membuat grafik batang rata-rata pada Gambar 3.17. Pilih Bar => Mean and Standard Deviation, Input: Multiple Numeric Variables (Gambar 3.18). Selanjutnya pilih Bar I (Gambar 3.19). Pindahkan variabel matematika, fisika, kimia dan biologi ke kotak sebelah kanan pada Choose Numeric Variable (Multiple Choices). Maksud dari Multiple Choices adalah Anda dapat memasukkan lebih dari satu variabel ke kotak sebelah kanan. Hasil dari grafik batang rata-rata dapat dilihat pada bagian Result.

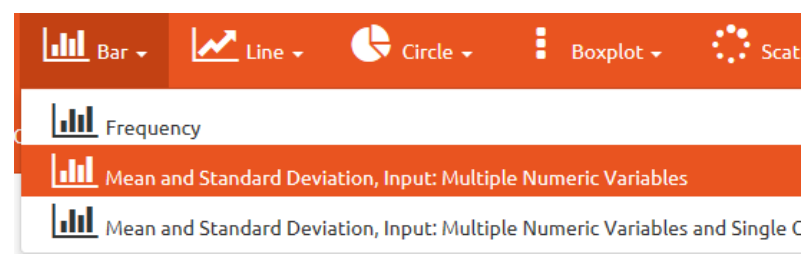

Gambar 3.18 Menu Grafik Batang Rata-Rata 
Llll Bar।

\section{Bar I: Mean and Standard Deviation Input: Multiple Numeric Variables}

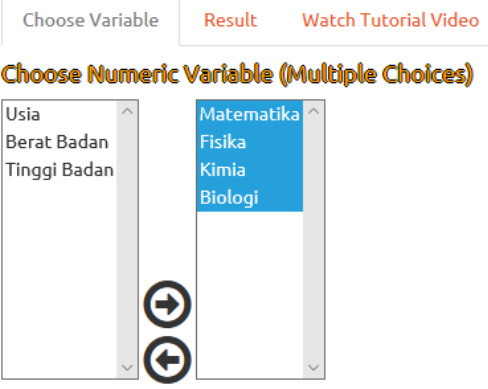

\section{Gambar 3.19 Bar I: Mean and Standard Deviation Input: Multiple Numeric Variables}

\subsection{Membuat Grafik Batang Rata-Rata (Input: Lebih dari Satu Variabel Numerik dan Satu Variabel Kategori)}

Selanjutnya akan dibuat grafik batang rata-rata dengan input lebih dari satu variabel numerik dan satu variabel kategori. Pada Gambar 3.20 merupakan grafik batang rata-rata yang melibatkan 4 varaibel numerik, yakni matematika, fisika, kimia dan biologi, serta melibatkan 1 variabel kategori, yakni jenis kelamin. Sebagai contoh, diketahui rata-rata nilai matematika pada laki-laki adalah 72,22 dengan standar deviasi 8,18 , sementara rata-rata nilai matematika pada perempuan adalah 67,17 dengan standar deviasi 8,16 .

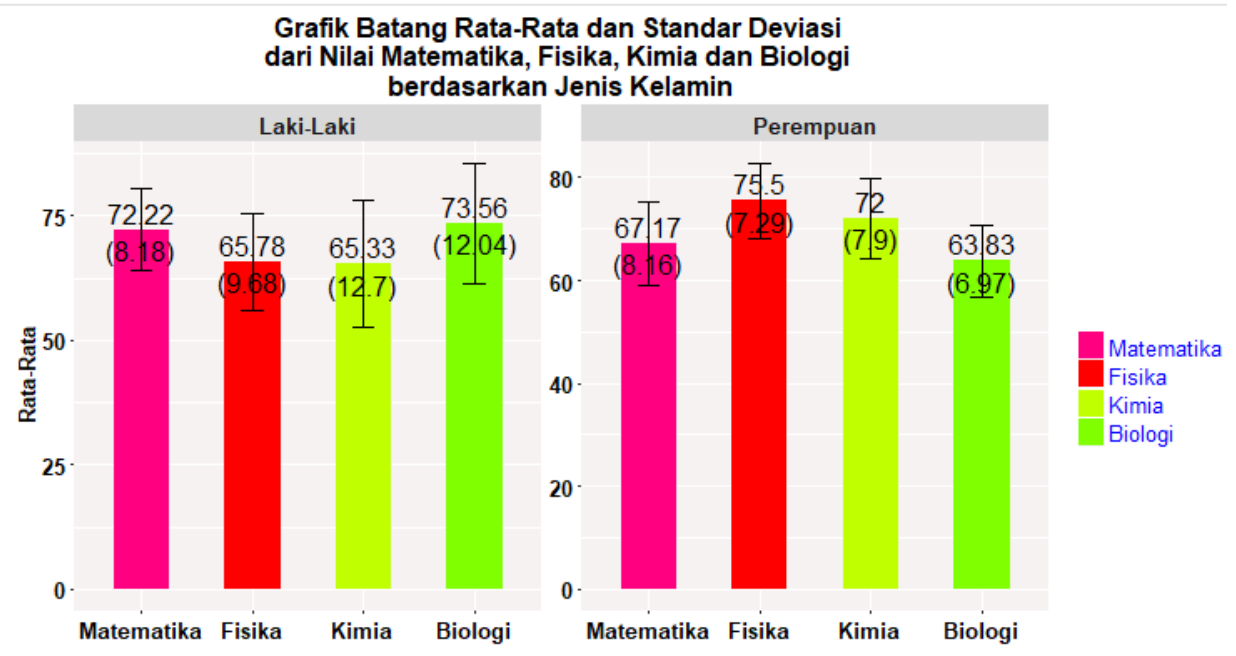




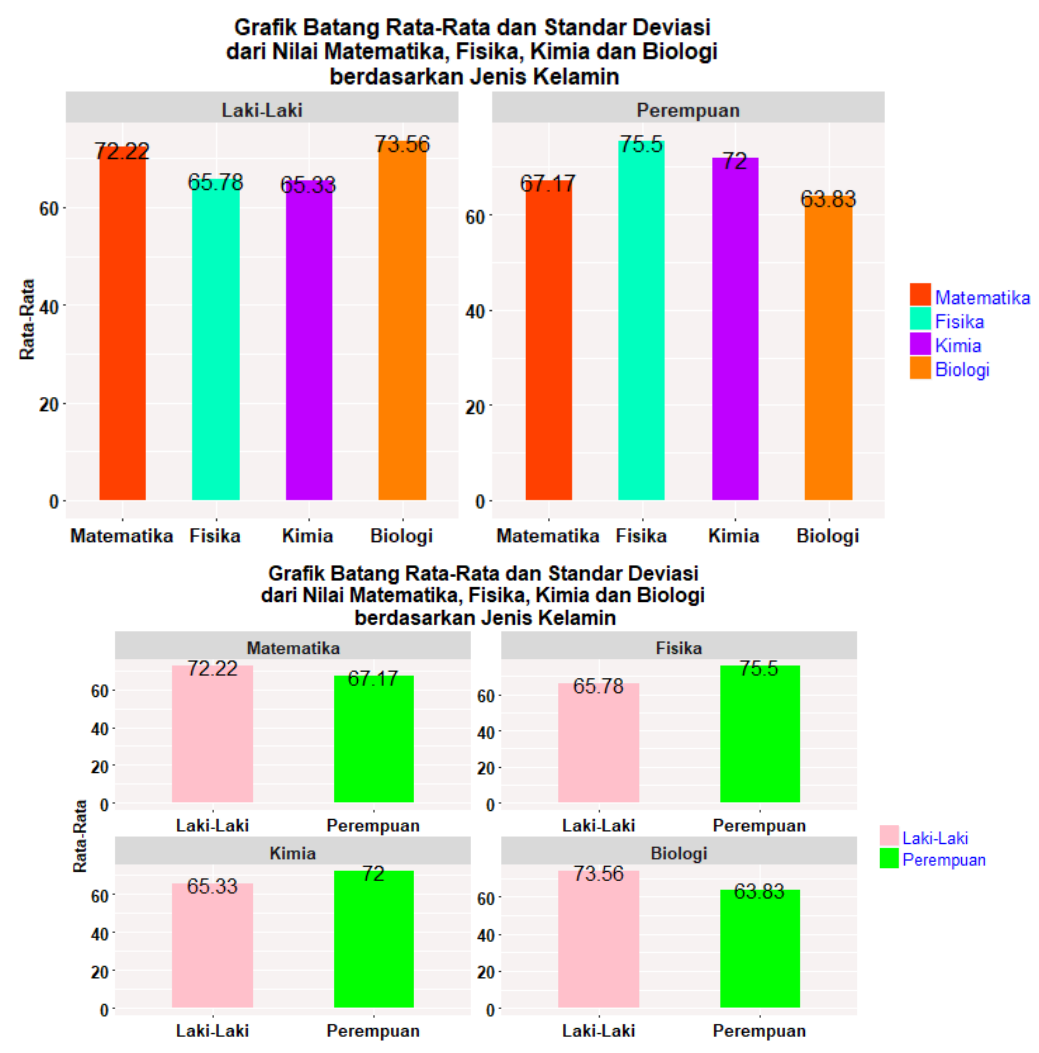

\section{Gambar 3.20 Grafik Batang Rata-Rata dan Standar Deviasi dari Nilai Matematika, Fisika, Kimia dan Biologi berdasarkan Jenis Kelamin}

Untuk membuat grafik batang rata-rata seperti pada Gambar 3.20, pilih Bar => Mean and Standard Deviation, Input: Multiple Numeric Variables and Single Categorical Variable (Gambar 3.21). Selanjutnya masukkan variabel matematika, fisika, kimia dan biologi ke kotak sebelah kanan pada Choose Numeric Variable (Multiple Choices), sementara variabel kategori jenis kelamin juga dipindahkan ke kotak sebelah kanan pada Choose Categorical Variable (Single Choice) (Gambar 3.22). Hasil dari grafik batang rata-rata dapat dilihat pada bagian Result.

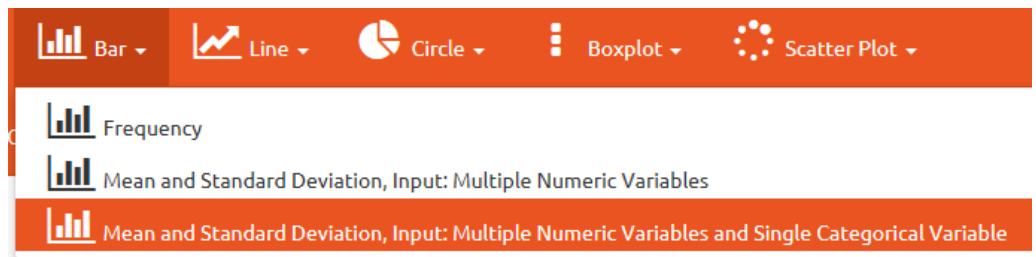

Gambar 3.21 Menu Grafik Batang Rata-Rata 
Bar I: Mean and Standard Deviation

Input: Multiple Numeric Variables and Single Categorical Variable

Choose Variable Result Watch Tutorial Video

Choose Nunieric Variable (Mullipile Choices)

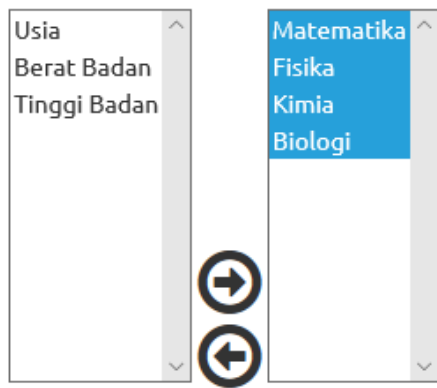

Choose Caltegorical Variable (Single Choice)

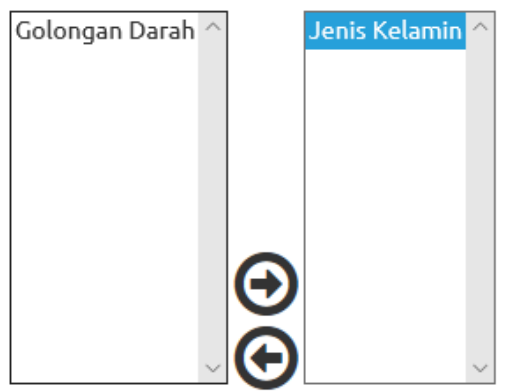

Gambar 3.22 Bar I: Mean and Standard Deviation

Input: Multiple Numeric Variables and Single Categorical Variable 


\section{BAB 4}

\section{MEMBUAT GRAFIK GARIS}

Pada pemaparan sebelumnya telah dijelaskan bagaimana membuat berbagai grafik batang, baik itu grafik batang frekuensi atau grafik batang rata-rata. Kali ini akan diberikan beberapa contoh membuat grafik garis di STATCAL-VISUALIZATION. Menu Line untuk membuat berbagai grafik garis. Dalam menu Line, terdapat pilihan Frequency dan Mean and Standard Deviation (Gambar 4.1). Pilihan Frequency untuk membuat berbagai grafik garis frekuensi, sementara pilihan Mean and Standard Deviation untuk membuat grafik garis rata-rata dan standar deviasi. Pada pilihan Frequency, input berupa variabel kategori, sementara pada pilihan Mean and Standard Deviation, input dapat berupa variabel numerik atau kombinasi dari variabel numerik dan variabel kategori.

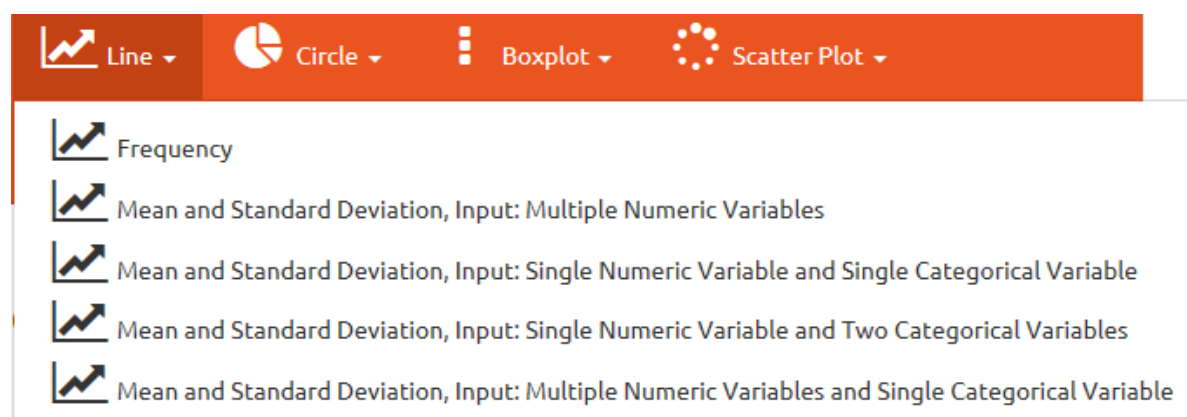

\section{Gambar 4.1 Menu Grafik Garis}

\subsection{Membuat Grafik Garis Frekuensi (Input: Satu Variabel Kategori)}

Berdasarkan data kategori yang telah diinput pada Gambar 2.3, akan dibuat grafik garis frekuensi berdasarkan variabel golongan darah, seperti pada Gambar 4.2. Diketahui terdapat 5 (33,33\%) siswa dengan golongan darah A, 3 (20\%) dengan golongan darah B, 4 (26,67\%) dengan golongan darah AB dan 3 (20\%) dengan golongan darah O. 


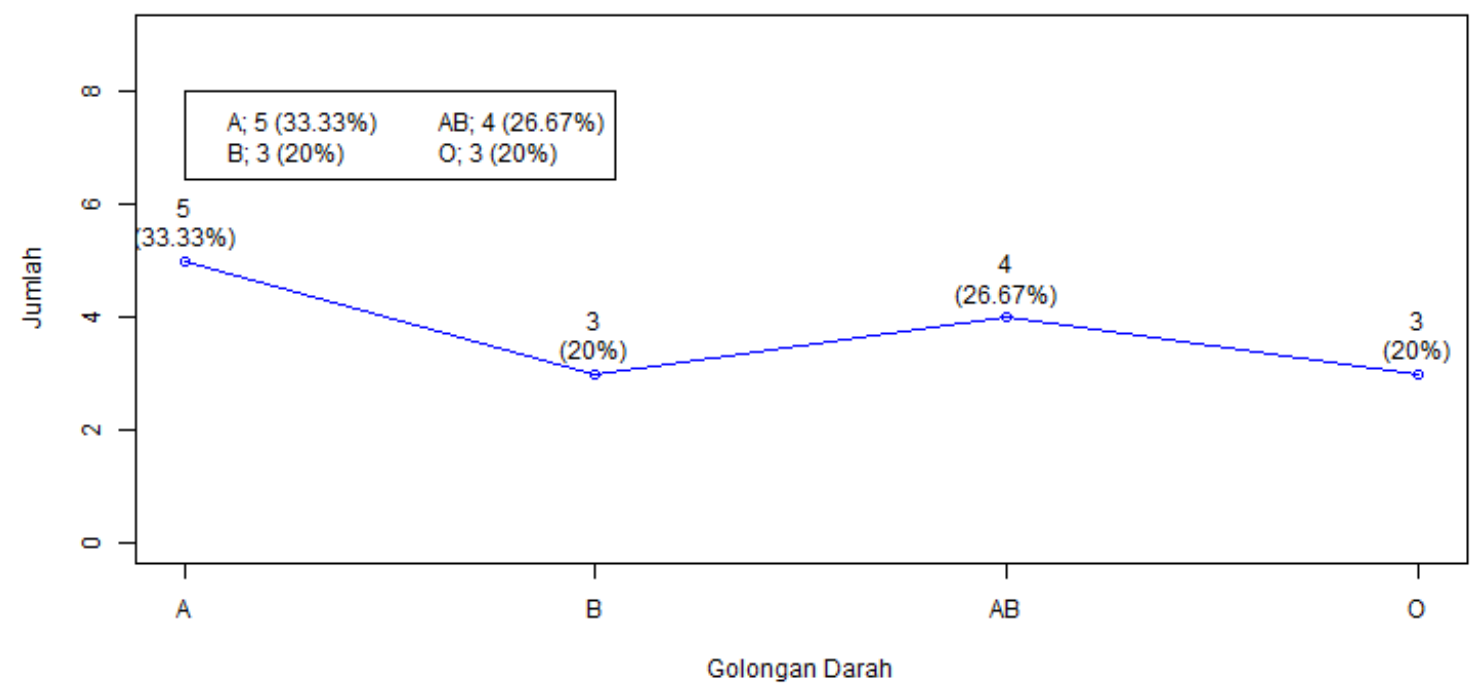

Gambar 4.2 Grafik Garis Frekuensi berdasarkan Golongan Darah

Untuk membuat grafik garis pada Gambar 4.2, pilih Line $=>$ Frequency (Gambar 4.1). Kemudian pilih Input: One Variable => Line I (Gambar 4.3). Sekarang Anda berada pada bagian Choose Variable. Pada bagian Choose Variable ini, Anda dapat memindahkan satu variabel kategori (Single Choice) ke bagian kotak sebelah kanan Choose Categorical Variable (Single Choice). Pada contoh Gambar 4.3, variabel golongan darah dipindahkan ke kotak sebelah kanan. Selanjutnya hasil dari grafik garis frekuensi dapat dilihat pada bagian Result (Gambar 4.4).

Pada bagian Result, dapat dilakukan berbagai pengaturan dari grafik garis frekuensi, seperti menampilkan frekuensi atau persentase, judul, dan sebagainya (Gambar 4.5). Di samping itu, terdapat menu Watch Tutorial Video. Di dalam menu Watch Tutorial Video disisipkan video yang dapat diputar dengan syarat terkoneksi internet. Video tersebut akan memandu Anda langkah-langkah membuat grafik garis frekuensi terkait. 


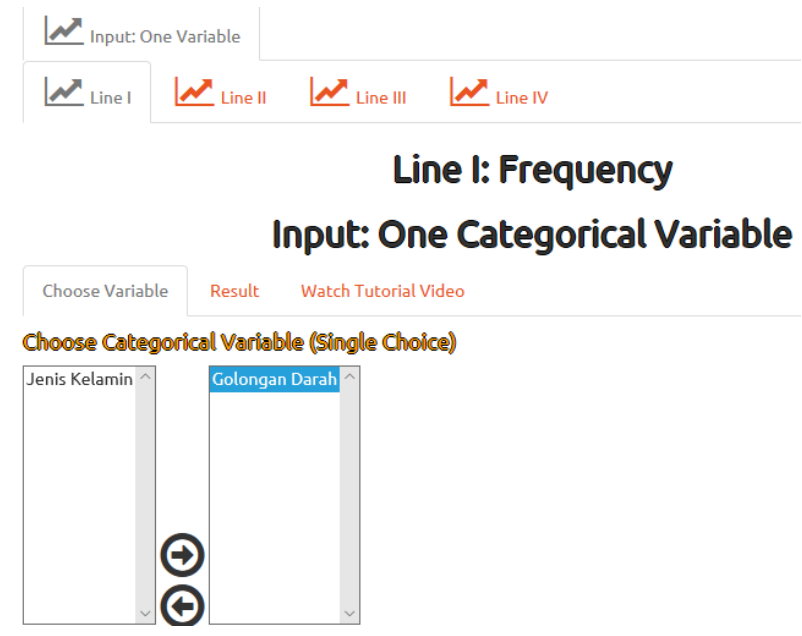

Gambar 4.3 Line I: Frequency

Input: One Categorical Data

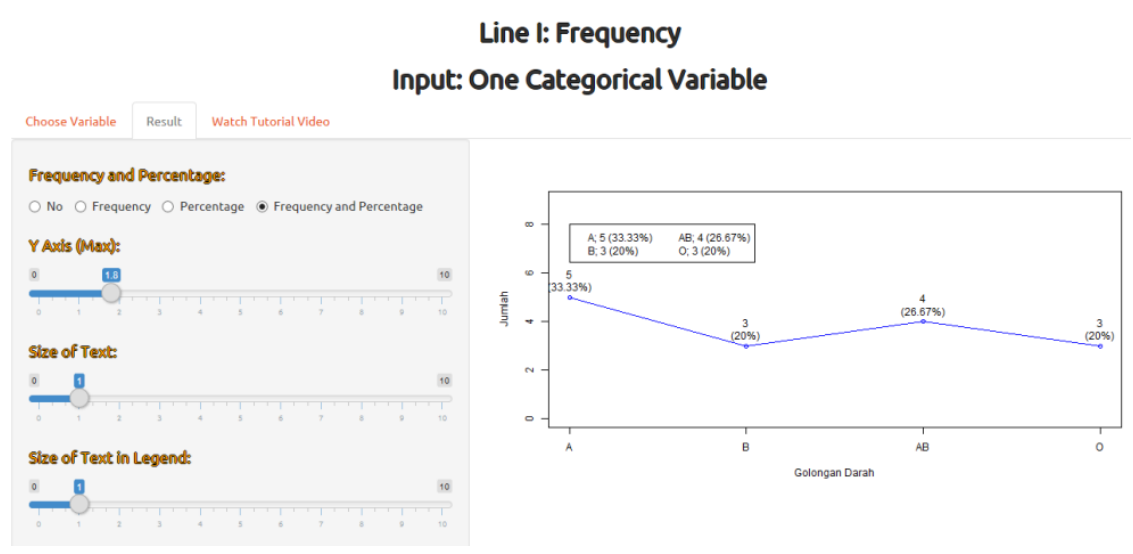

Gambar 4.4 Result

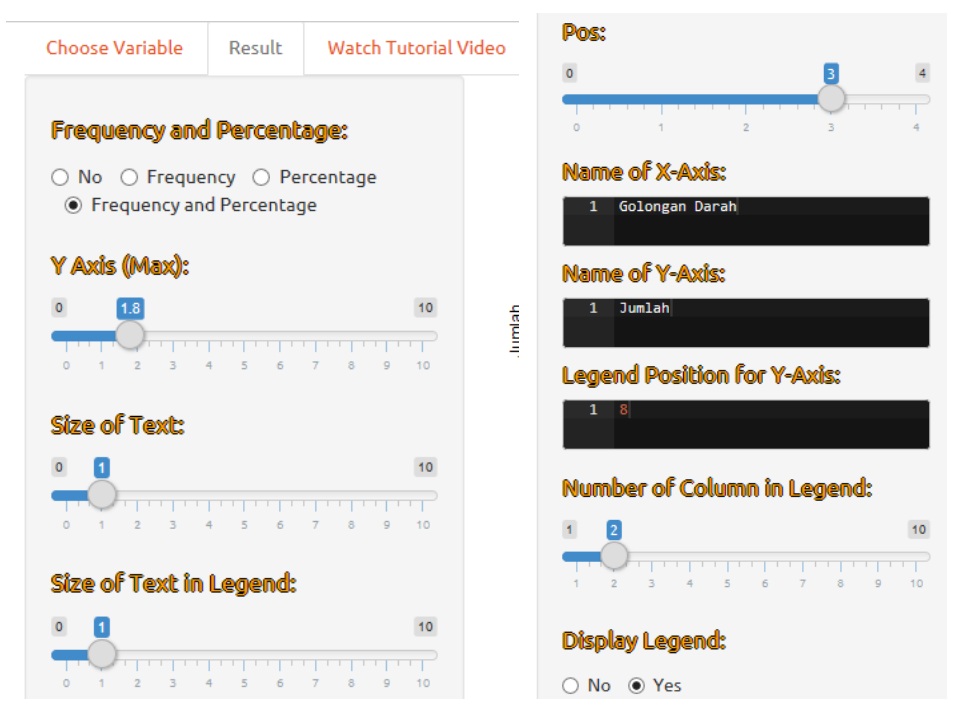

Gambar 4.5 Berbagai Pengaturan Grafik Garis Frekuensi di Bagian Result 
Anda juga dapat membuat grafik garis frekuensi dengan tampilan yang sedikit berbeda, seperti pada Gambar 4.6 (menu Line III) dan Gambar 4.7 (menu Line III).

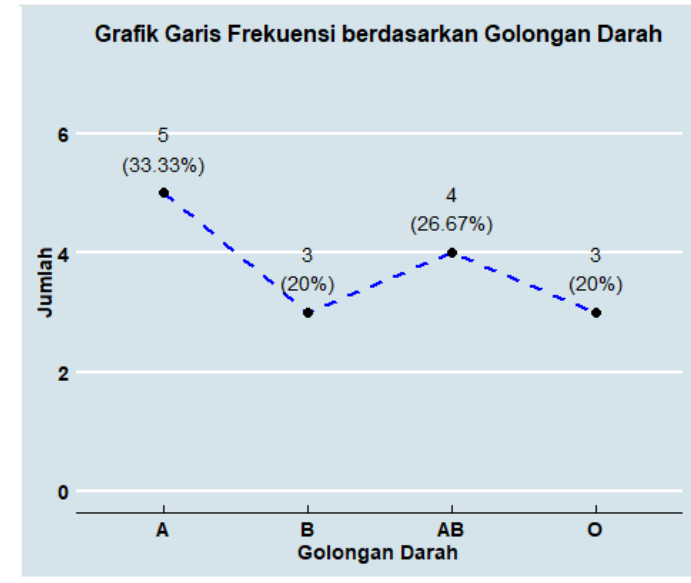

Gambar 4.6 Grafik Garis Frekuensi (Line III)

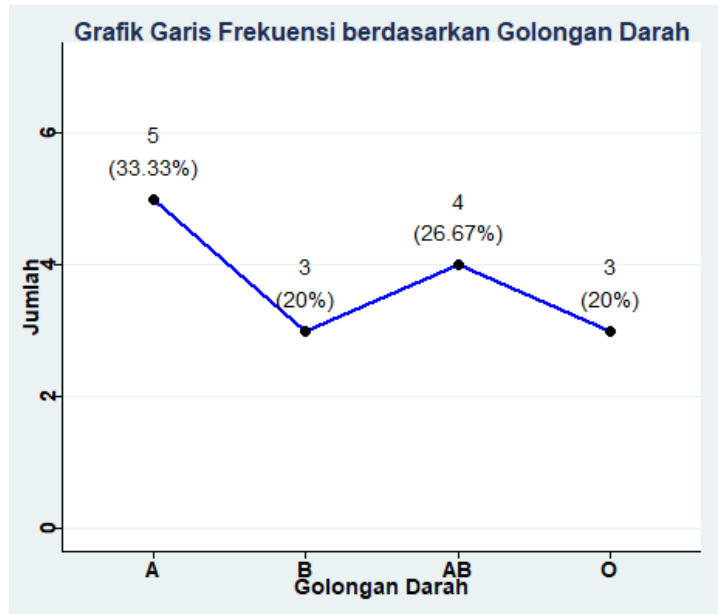

Gambar 4.7 Grafik Garis Frekuensi (Line III)

Misalkan diberikan data distribusi frekuensi berdasarkan golongan darah seperti pada Tabel 4.1. Anda tetap dapat membuat grafik garis frekuensi seperti pada Gambar 4.2 dengan menggunakan menu Line II dan Line IV (Gambar 4.8). Masukkan data pada Tabel 4.1 ke kotak Label dan Frequency (Gambar 4.8). Hasilnya dapat dilihat pada bagian Result. 
Tabel 4.1 Distribusi Frekuensi berdasarkan Golongan Darah

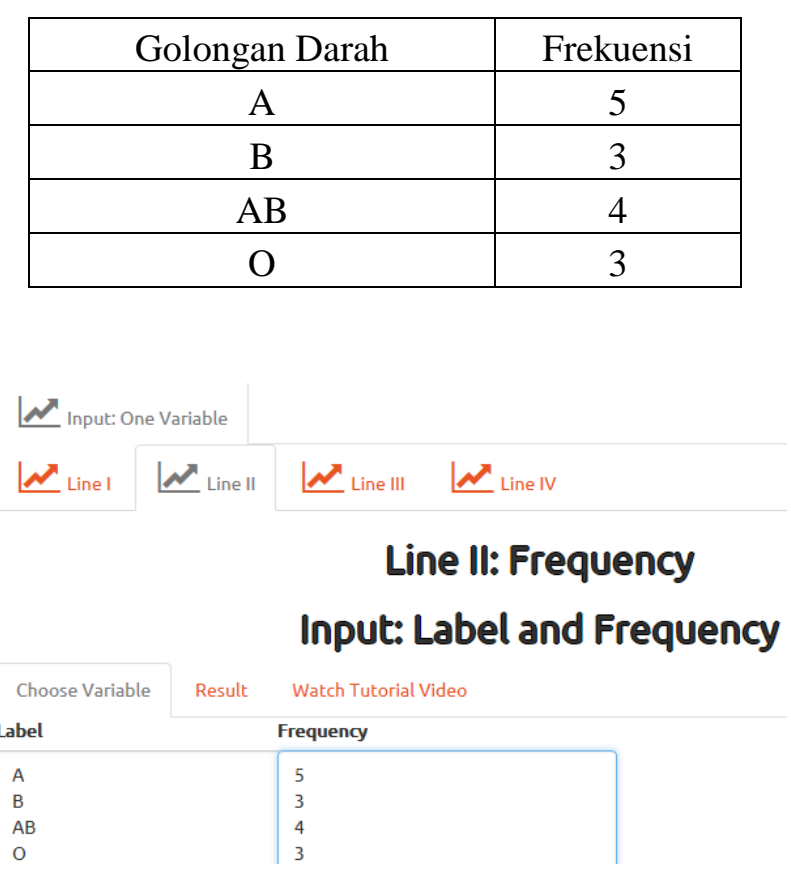

Gambar 4.8 Line II

\subsection{Membuat Grafik Garis Rata-Rata (Input: Lebih dari Satu Variabel Numerik)}

Dari data pada Gambar 2.9, disajikan grafik garis rata-rata berdasarkan nilai ujian matematika, fisika, kimia dan biologi, seperti pada Gambar 4.9. Diketahui rata-rata ujian matematika adalah 70,2, dengan standar deviasi 8,28, rata-rata ujian fisika adalah 69,67, dengan standar deviasi 9,84, dan seterusnya.

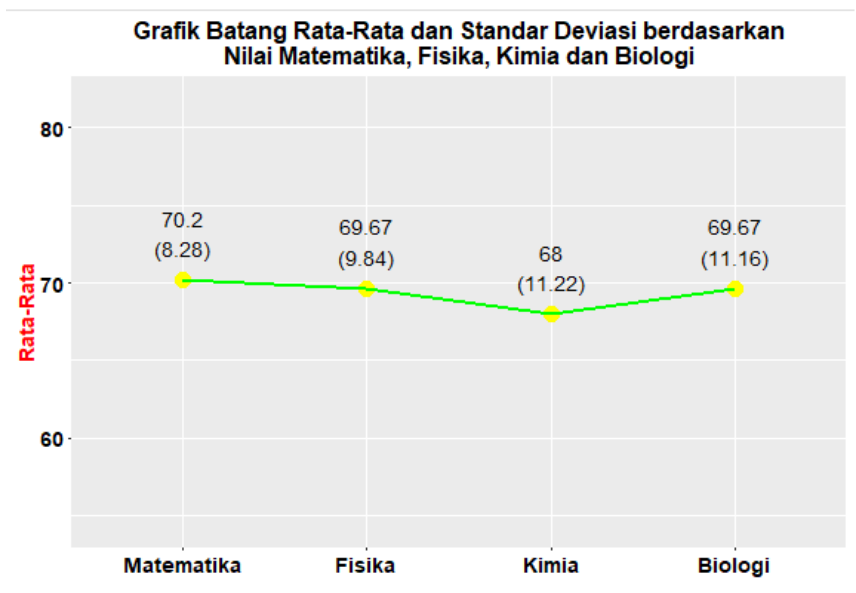

Gambar 4.9 Grafik Garis Rata-Rata dan Standar Deviasi berdasarkan Nilai Matematika, Fisika, Kimia dan Biologi 
Berikut tahapan untuk membuat grafik garis rata-rata pada Gambar 4.9. Pilih Line $=>$ Mean and Standard Deviation, Input: Multiple Numeric Variables (Gambar 4.1). Pada kotak Choose Numeric Variable (Multiple Choices), pindahkan variabel matematika, fisika, kimia dan biologi ke kotak sebelah kanan (Gambar 4.10). Hasil dari grafik garis dapat dilihat pada bagian Result (Gambar 4.11). Berbagai pengaturan seperti warna garis, jenis garis, judul dan frekuensi dapat diatur pada bagian Result.

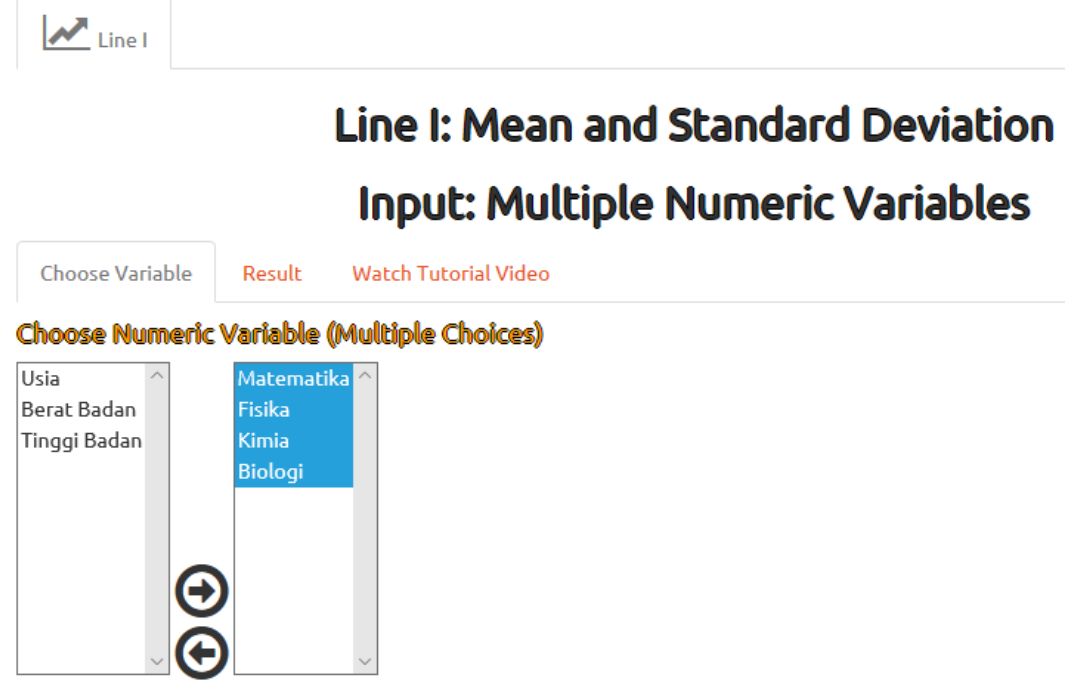

Gambar 4.10 Line I: Mean and Standard Deviation Input: Multiple Numeric Variables
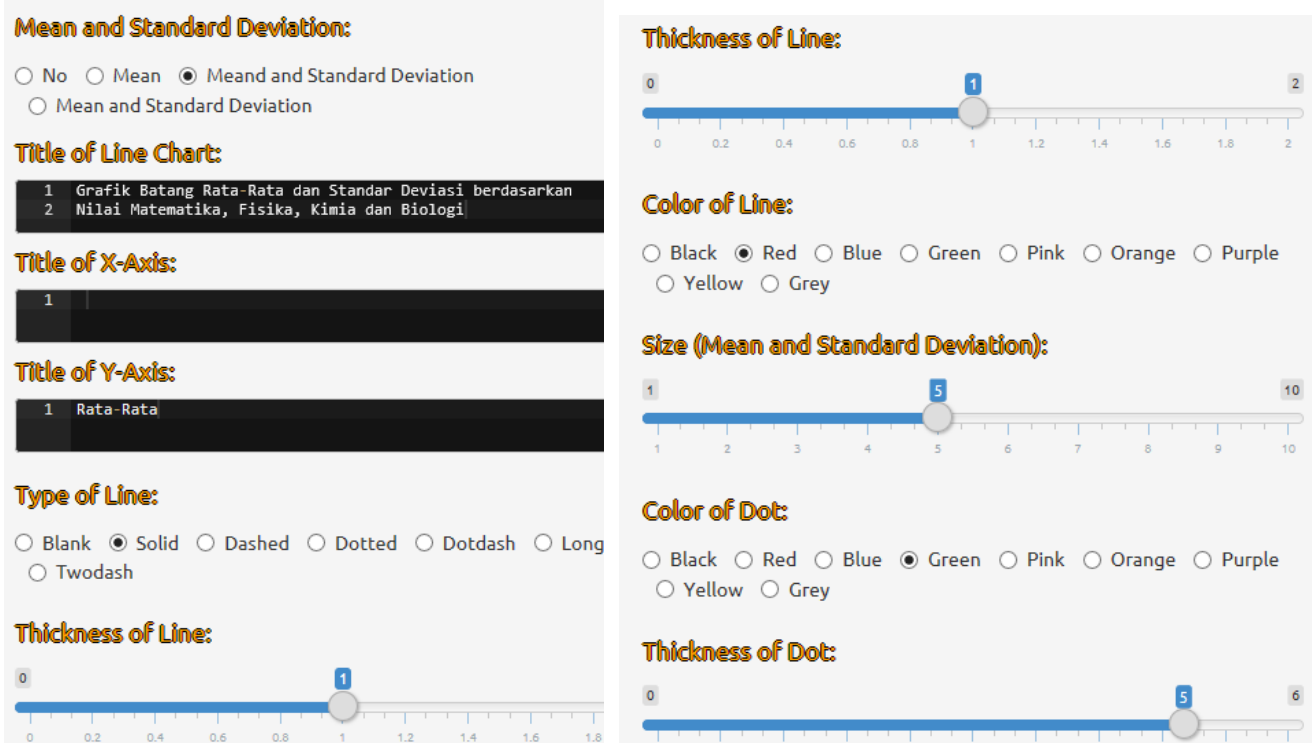

Gambar 4.11 Berbagai Pengaturan Grafik Garis pada Bagian Result 


\subsection{Membuat Grafik Garis Rata-Rata (Input: Satu Variabel Numerik dan Satu Variabel}

Kategori)

Dari data kategori dan numerik yang telah diinput pada Bab 2, dibuat grafik garis rata-rata nilai ujian matematika berdasarkan jenis kelamin, seperti pada Gambar 4.12. Diketahui ratarata matematika untuk jenis kelamin laki-laki adalah 72,22 dengan standar deviasi 8,18, sementara rata-rata matematika untuk jenis kelamin perempuan adalah 67,17 dengan standar deviasi 8,16 .

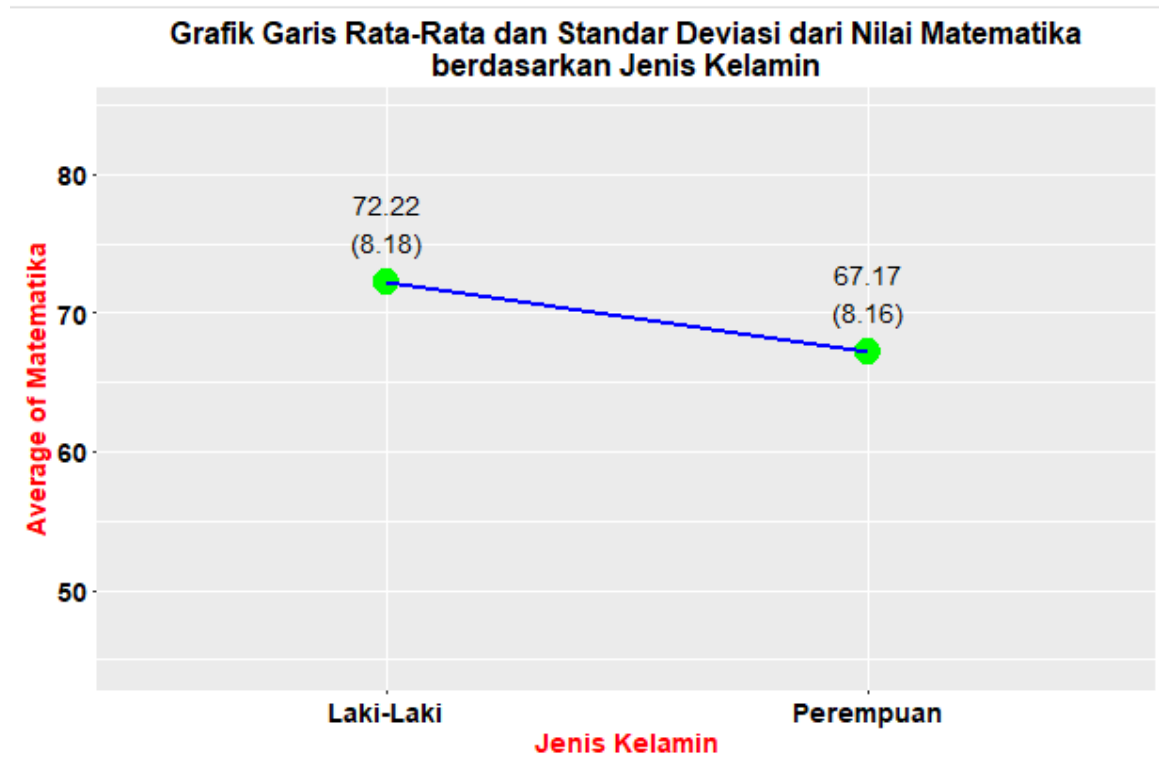

\section{Gambar 4.12 Grafik Garis Rata-Rata dan Standar Deviasi dari Nilai Matematika berdasarkan Jenis kelamin}

Berikut tahapan untuk membuat grafik garis rata-rata pada Gambar 4.12. Pilih Line => Mean and Standard Deviation, Input: Single Numeric Variable and Single Categorical Variable (Gambar 4.1). Pada kotak Choose Numeric Variable (Single Choice), pindahkan variabel matematika ke kotak sebelah kanan, sementara pada kotak Choose Categorical Variable (Single Choice), pindahkan variabel jenis kelamin ke kotak sebelah kanan (Gambar 4.13). Hasil dari grafik garis dapat dilihat pada bagian Result. 


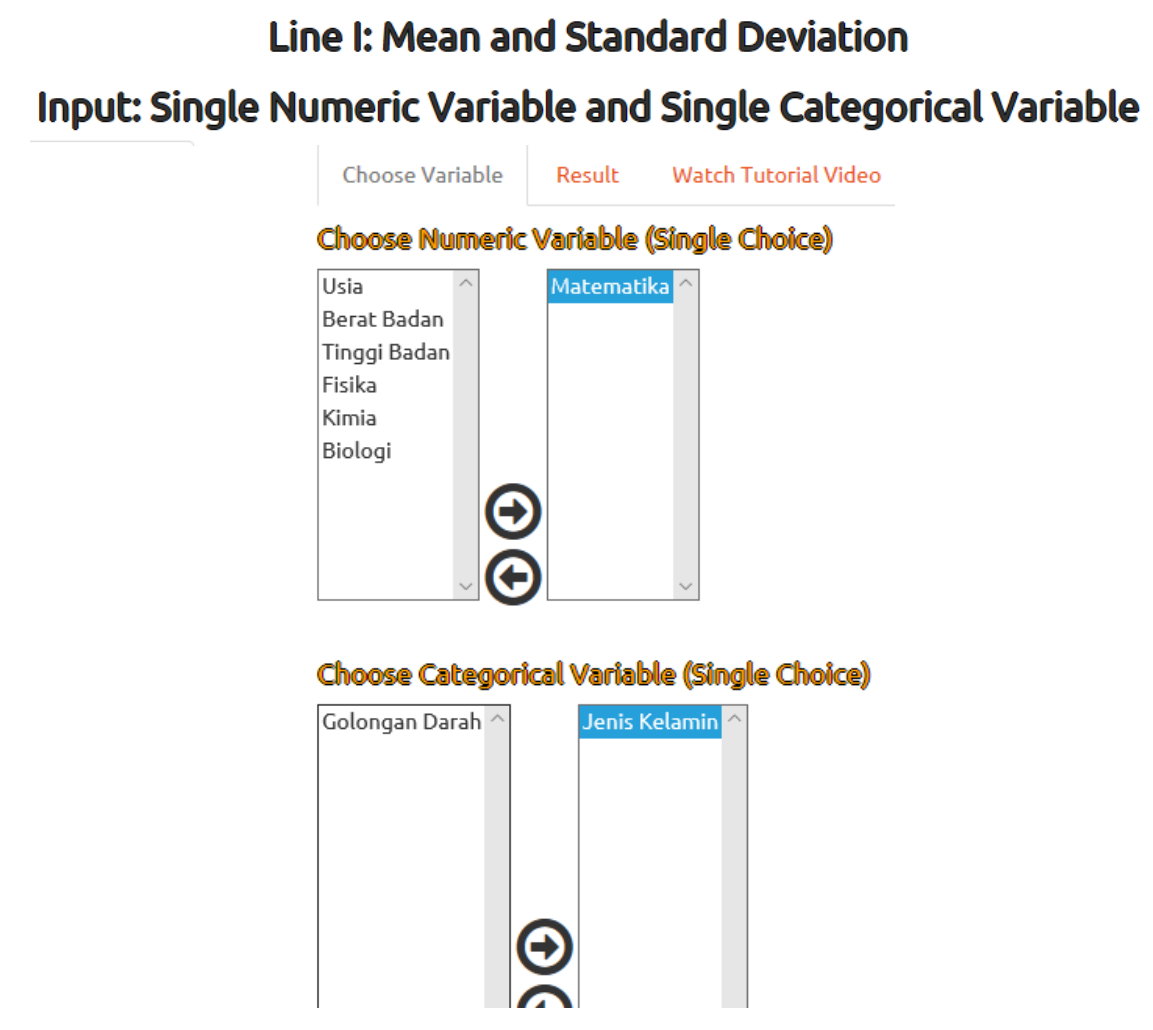

\section{Gambar 4.13 Line I: Mean and Standard Deviation \\ Input: Single Numeric Variable and Single Categorical Variable}

4.4 Membuat Grafik Garis Rata-Rata (Input: Lebih dari Satu Variabel Numerik dan Satu Variabel Kategori)

Selanjutnya akan dibuat grafik garis rata-rata dengan input lebih dari satu variabel numerik dan satu variabel kategori. Pada Gambar 4.14 merupakan grafik garis rata-rata yang melibatkan 4 variabel numerik, yakni matematika, fisika, kimia dan biologi, serta melibatkan 1 variabel kategori, yakni jenis kelamin. Sebagai contoh, diketahui rata-rata nilai matematika pada laki-laki adalah 72,22 dengan standar deviasi 8,18, sementara rata-rata nilai matematika pada perempuan adalah 67,17 dengan standar deviasi 8,16 . 


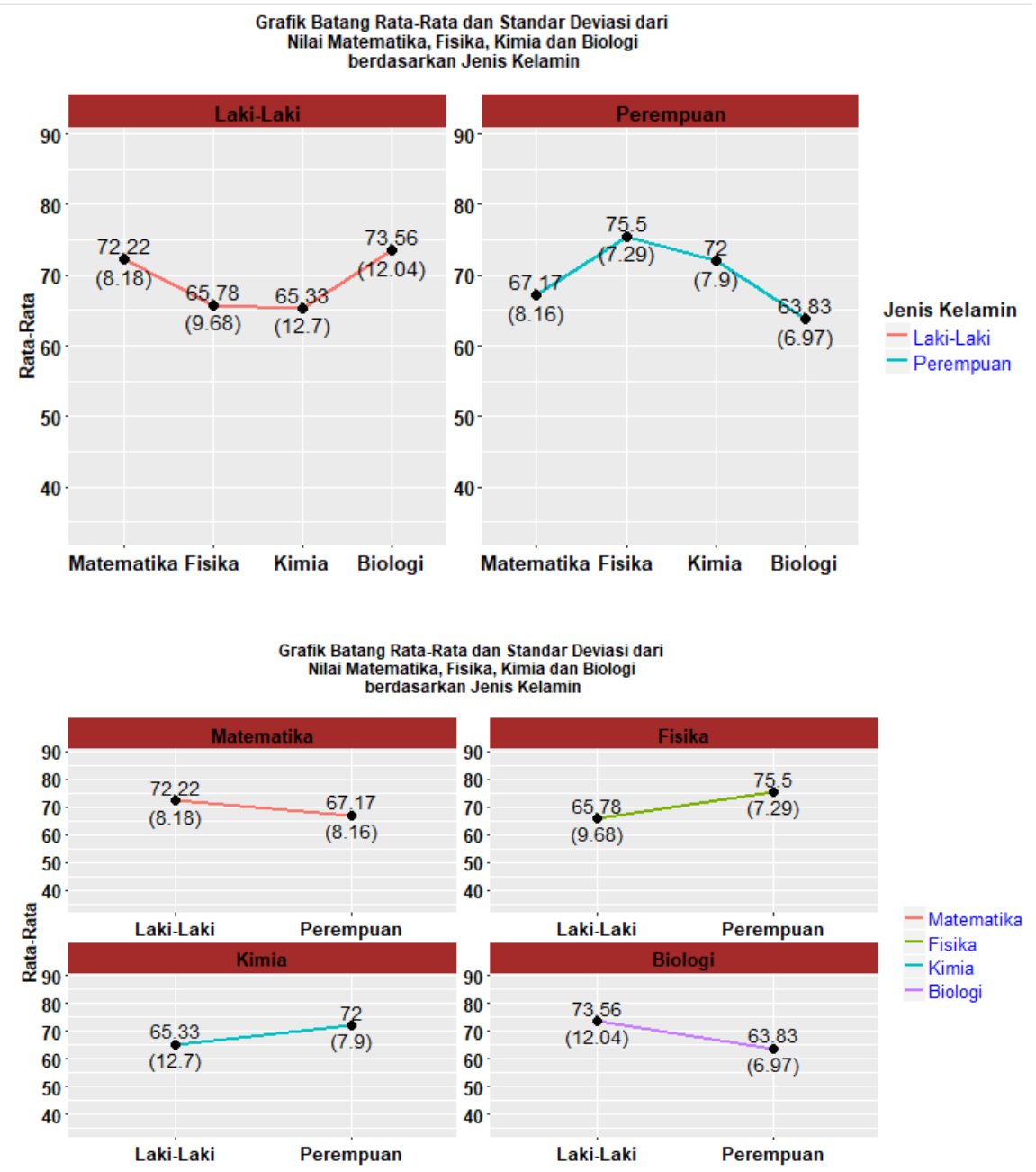

Gambar 4.14 Grafik Garis Rata-Rata dan Standar Deviasi dari Nilai Matematika, Fisika, Kimia dan Biologi berdasarkan Jenis Kelamin

Berikut tahapan untuk membuat grafik garis rata-rata pada Gambar 4.14. Pilih Line => Mean and Standard Deviation, Input: Multiple Numeric Variable and Single Categorical Variable (Gambar 4.1). Pada kotak Choose Numeric Variable (Multiple Choices), pindahkan variabel matematika, fisika, kimia dan biologi ke kotak sebelah kanan, sementara pada kotak Choose Categorical Variable (Single Choice), pindahkan variabel jenis kelamin ke kotak sebelah kanan (Gambar 4.15). Hasil dari grafik garis dapat dilihat pada bagian Result. 
Line I: Mean and Standard Deviation

Input: Multiple Numeric Variables and Single Categorical Variable

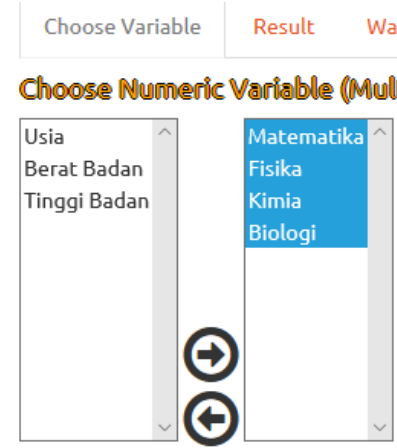

Choose Categorical Variable (Single Choice)

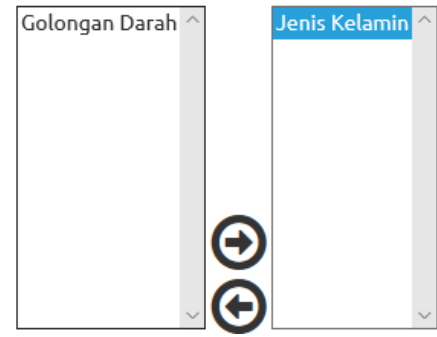

Gambar 4.15 Bar I: Mean and Standard Deviation Input: Multiple Numeric Variables and Single Categorical Variable

\subsection{Membuat Grafik Garis Rata-Rata (Input: Satu Variabel Numerik dan Dua Variabel Kategori)}

Gambar 4.16 merupakan grafik garis rata-rata yang melibatkan 1 variabel numerik, yakni nilai matematika, dan 2 variabel kategori, yakni golongan darah dan jenis kelamin. Diketahui nilai rata-rata matematika untuk golongan darah $\mathrm{A}$, jenis kelamin perempuan adalah 65 , sementara rata-rata matematika untuk golongan darah $\mathrm{A}$, jenis kelamin laki-laki adalah 76,67. Nilai ratarata matematika untuk golongan darah $\mathrm{B}$, jenis kelamin perempuan adalah 74,5 , sementara rata-rata matematika untuk golongan darah $\mathrm{B}$, jenis kelamin laki-laki adalah 66. Berikut tahapan untuk membuat grafik garis rata-rata pada Gambar 4.16. Pilih Line => Mean and Standard Deviation, Input: Single Numeric Variable and Two Categorical Variable (Gambar 4.1). 


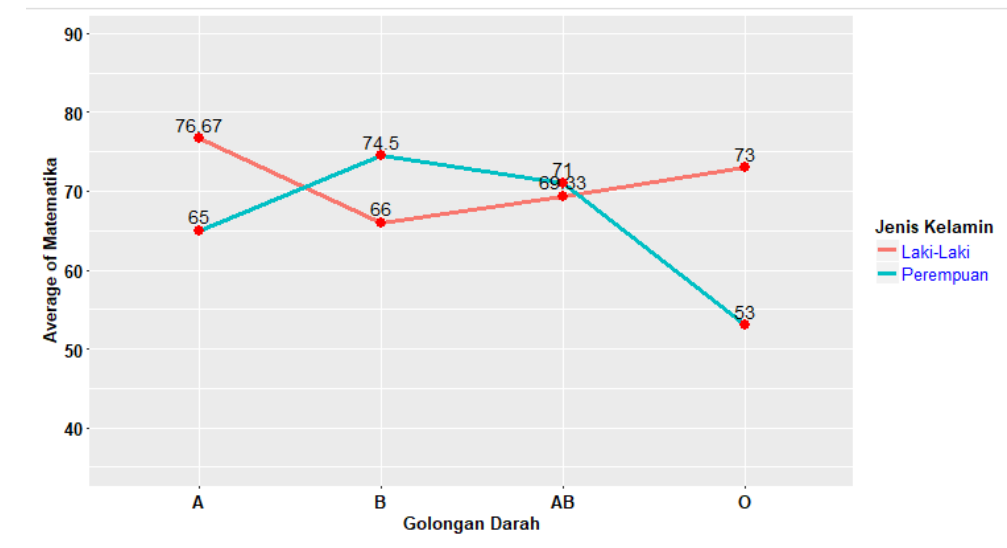

\section{Gambar 4.16 Grafik Garis Rata-Rata dari Nilai Matematika berdasarkan Golongan Darah dan Jenis Kelamin}

Pada kotak Choose Numeric Variable (Single Choice), pindahkan variabel matematika ke kotak sebelah kanan, pada kotak Choose Categorical Variable (Single Choice) (X-Axis), pindahkan variabel jenis kelamin ke kotak sebelah kanan dan pada kotak Choose Categorical Variable (Single Choice) (Group), pindahkan variabel jenis kelamin ke kotak sebelah kanan (Gambar 4.17). Hasil dari grafik garis dapat dilihat pada bagian Result.

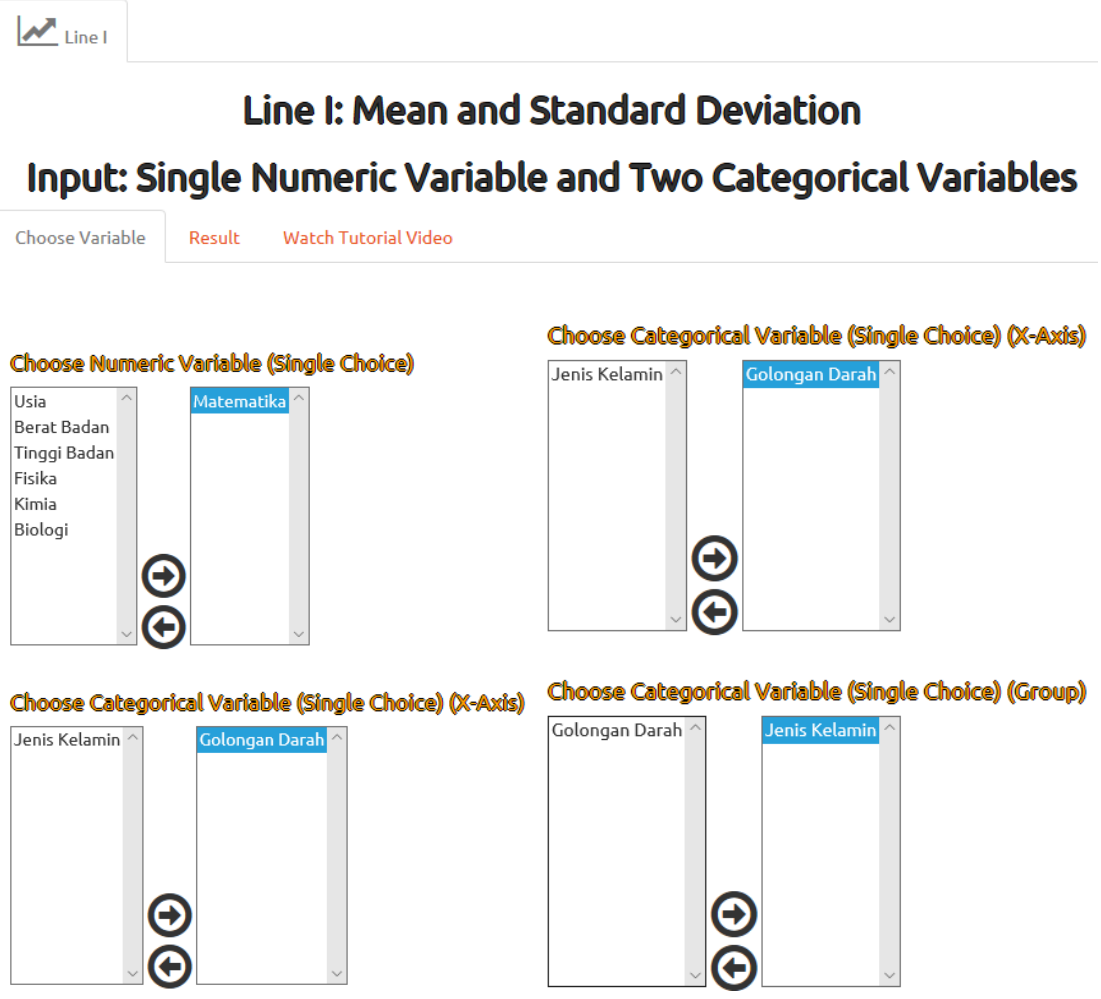

Gambar 4.17 Line I: Mean and Standard Deviation Input: Single Numeric Variable and Two Categorical Variables 


\section{BAB 5}

\section{MEMBUAT GRAFIK LINGKARAN}

Pada pemaparan sebelumnya telah dijelaskan bagaimana membuat berbagai grafik garis, baik itu grafik garis frekuensi atau grafik garis rata-rata. Kali ini akan diberikan beberapa contoh membuat grafik lingkaran di STATCAL-VISUALIZATION. Menu Circle untuk membuat berbagai grafik lingkaran. Dalam menu Circle, terdapat pilihan Frequency dan Mean and Standard Deviation (Gambar 5.1). Pilihan Frequency untuk membuat berbagai grafik lingkaran frekuensi, sementara pilihan Mean and Standard Deviation untuk membuat grafik lingkaran rata-rata dan standar deviasi. Pada pilihan Frequency, input berupa variabel kategori, sementara pada pilihan Mean and Standard Deviation, input dapat berupa variabel numerik atau kombinasi dari variabel numerik dan variabel kategori.

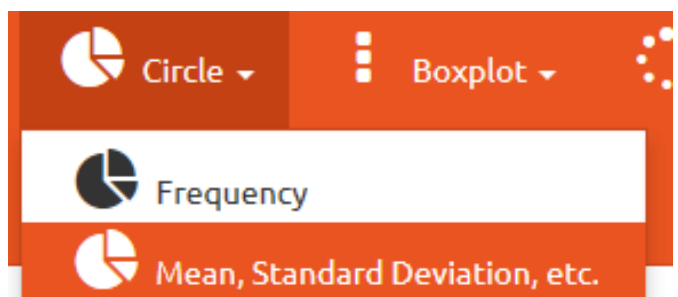

\section{Gambar 5.1 Menu Grafik Lingkaran}

\subsection{Membuat Grafik Lingkaran Frekuensi (Input: Satu Variabel Kategori)}

Berdasarkan data kategori yang telah diinput pada Gambar 2.3, akan dibuat grafik lingkaran frekuensi berdasarkan variabel golongan darah, seperti pada Gambar 5.2. Diketahui terdapat 5 $(33,33 \%)$ siswa dengan golongan darah A, 3 (20\%) dengan golongan darah B, $4(26,67 \%)$ dengan golongan darah AB dan 3 (20\%) dengan golongan darah O. 
Grafik Lingkaran Frekuensi berdasarkan Golongan Darah
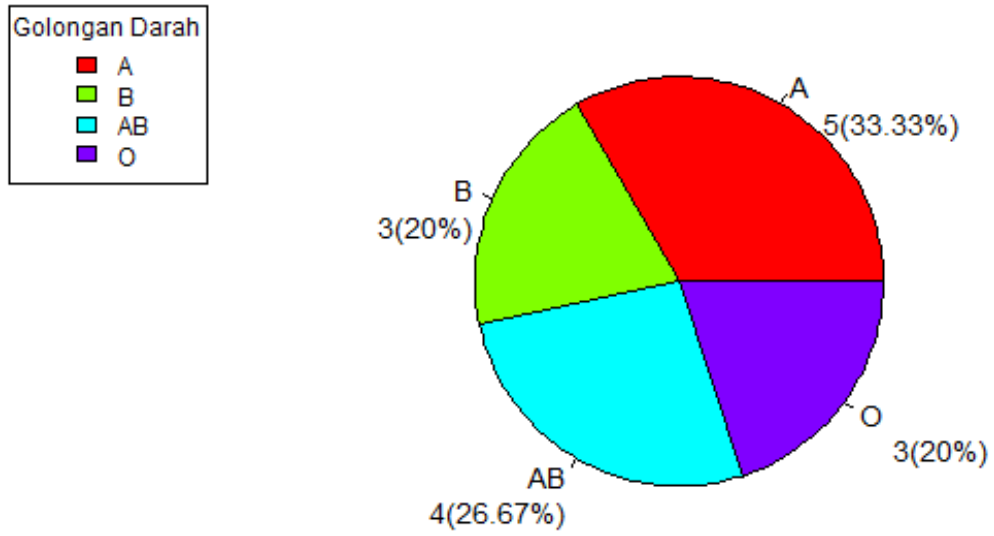

Gambar 5.2 Grafik Lingkaran Frekuensi berdasarkan Golongan Darah

Untuk membuat grafik lingkaran pada Gambar 5.2, pilih Circle => Frequency (Gambar 5.1). Kemudian pilih Input: One Variable $=>$ Circle I $($ Gambar 5.3).

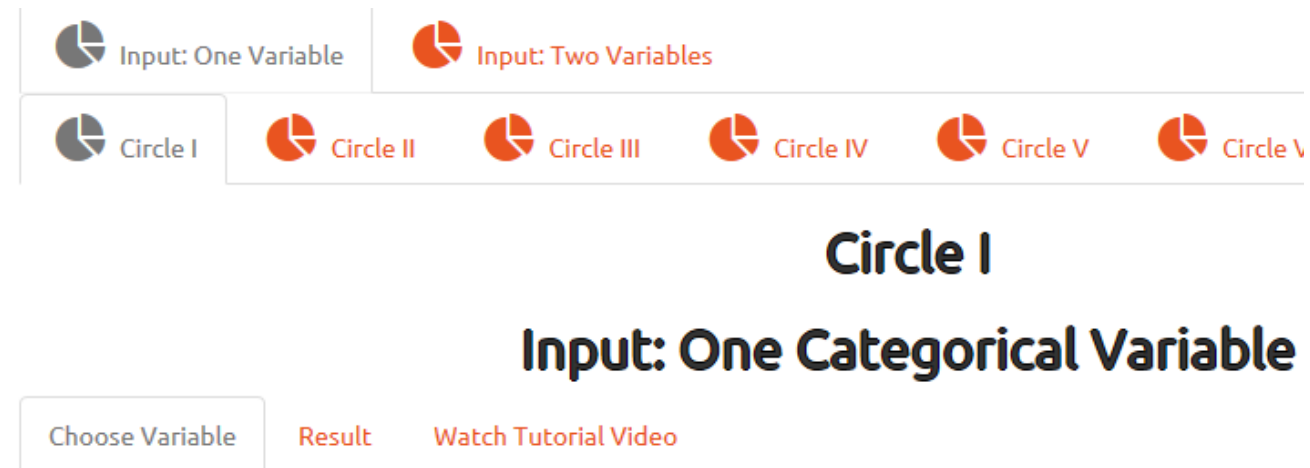

Choose Cattegorical Variable (Single Choice)

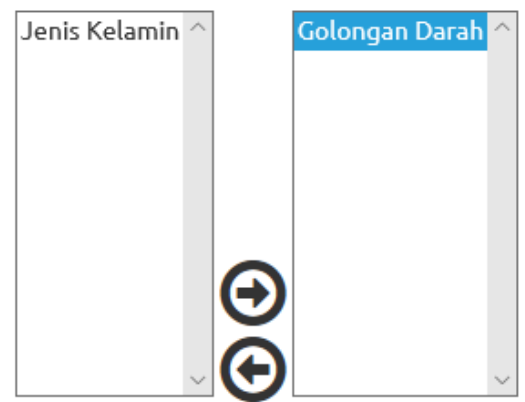

Gambar 5.3 Circle I: Frequency

Input: One Categorical Data 
Sekarang Anda berada pada bagian Choose Variable. Pada bagian Choose Variable ini, Anda dapat memindahkan satu variabel kategori (Single Choice) ke bagian kotak sebelah kanan Choose Categorical Variable (Single Choice). Pada contoh Gambar 5.3, variabel golongan darah dipindahkan ke kotak sebelah kanan. Selanjutnya hasil dari grafik lingkaran frekuensi dapat dilihat pada bagian Result (Gambar 5.4).

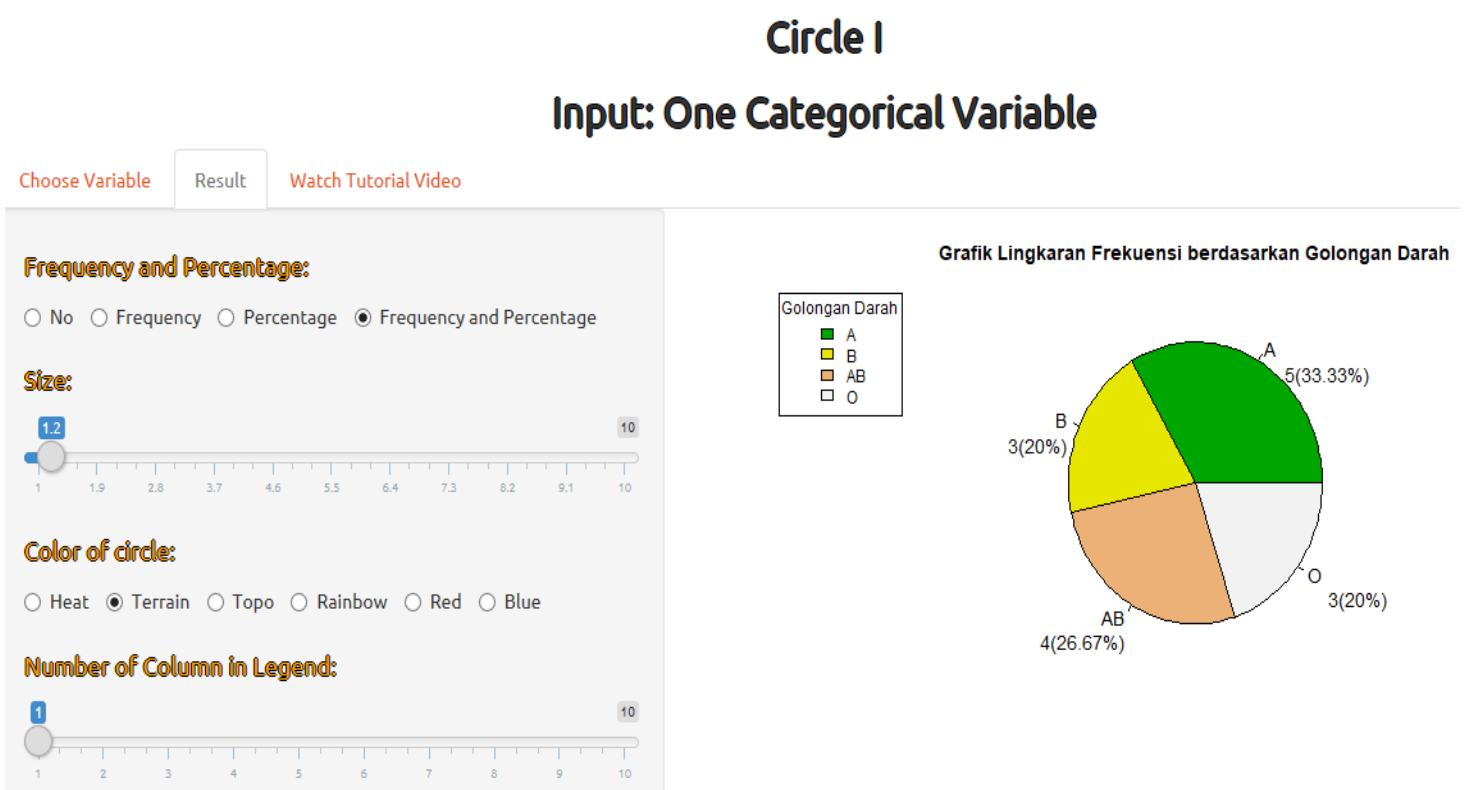

Gambar 5.4 Result
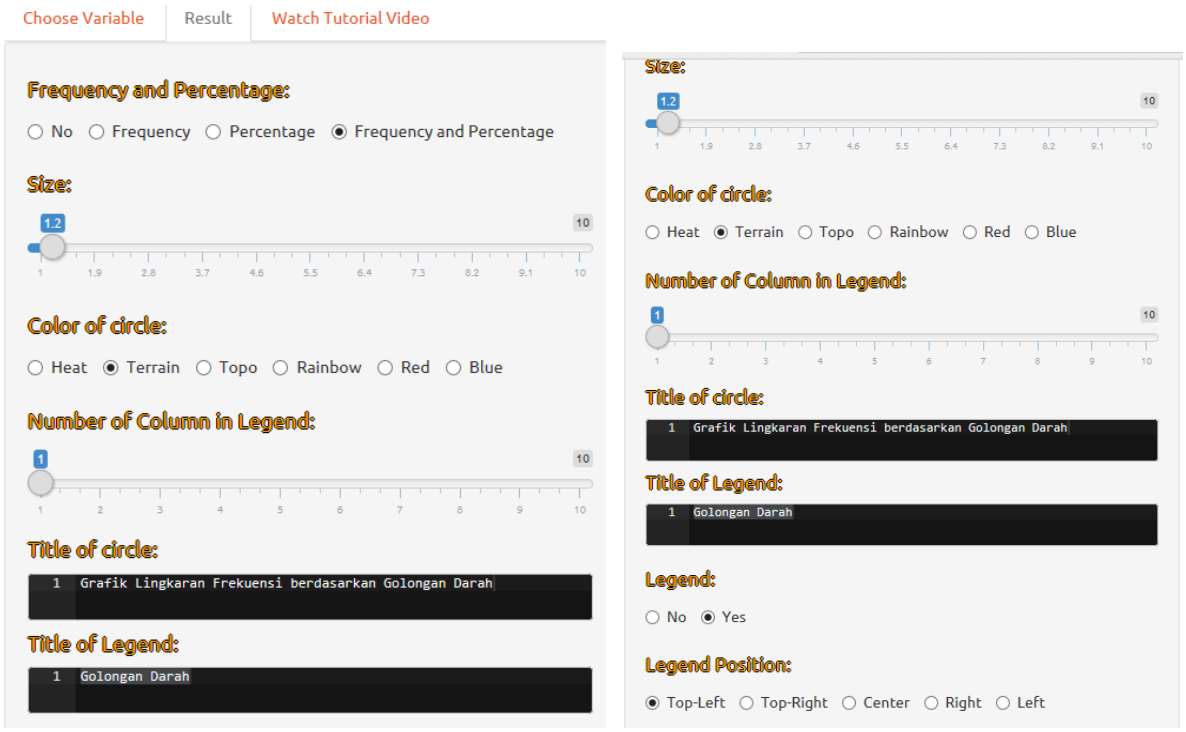

Gambar 5.5 Berbagai Pengaturan Grafik Lingkaran Frekuensi di Bagian Result 
Pada bagian Result, dapat dilakukan berbagai pengaturan dari grafik lingkaran frekuensi, seperti menampilkan frekuensi atau persentase, judul, dan sebagainya (Gambar 5.5). Di samping itu, terdapat menu Watch Tutorial Video. Di dalam menu Watch Tutorial Video disisipkan video yang dapat diputar dengan syarat terkoneksi internet. Video tersebut akan memandu Anda langkah-langkah membuat grafik lingkaran frekuensi terkait. Anda juga dapat membuat grafik lingkaran frekuensi dengan tampilan yang sedikit berbeda, seperti pada Gambar 5.6 (menu Circle III) dan Gambar 5.7 (menu Circle V).

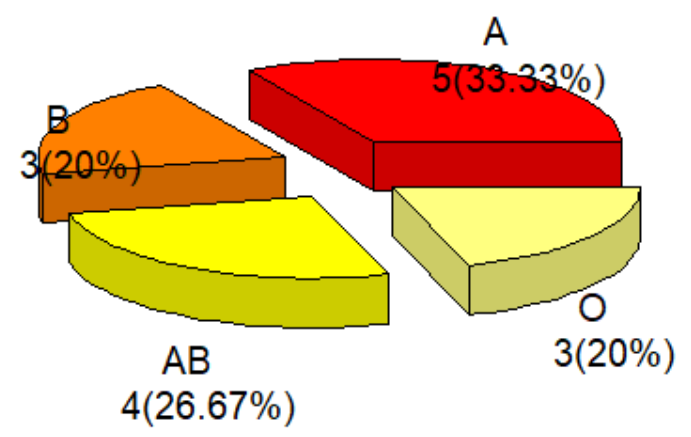

Gambar 5.6 Grafik Lingkaran Frekuensi (Circle III)

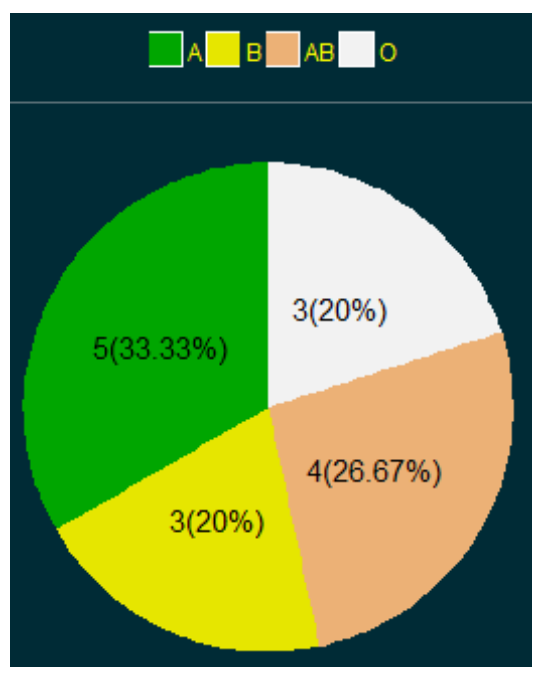

Gambar 5.7 Grafik Lingkaran Frekuensi (Circle V)

Misalkan diberikan data distribusi frekuensi berdasarkan golongan darah seperti pada Tabel 5.1. Anda tetap dapat membuat grafik lingkaran frekuensi seperti pada Gambar 5.2 dengan 
menggunakan menu Circle II, Circle IV dan Circle VI (Gambar 5.8). Masukkan data pada Tabel 5.1 ke kotak Label dan Frequency (Gambar 5.8). Hasilnya dapat dilihat pada bagian Result.

Tabel 5.1 Distribusi Frekuensi berdasarkan Golongan Darah

\begin{tabular}{|c|c|}
\hline Golongan Darah & Frekuensi \\
\hline $\mathrm{A}$ & 5 \\
\hline $\mathrm{B}$ & 3 \\
\hline $\mathrm{AB}$ & 4 \\
\hline $\mathrm{O}$ & 3 \\
\hline
\end{tabular}

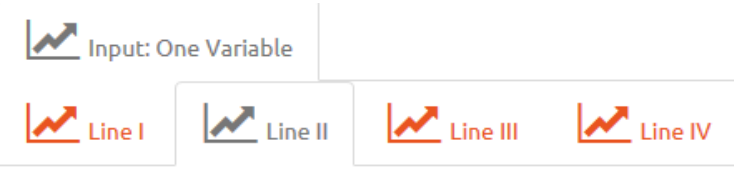

Line II: Frequency Input: Label and Frequency

\begin{tabular}{|c|c|c|}
\hline Choose Variable & Result & Watch Tutorial Video \\
\hline Label & & Frequency \\
\hline A & & 5 \\
\hline B & & 3 \\
\hline$A B$ & & 4 \\
\hline 0 & & 3 \\
\hline
\end{tabular}

Gambar 5.8 Circle II

\subsection{Membuat Grafik Lingkaran Frekuensi (Input: Dua Variabel Kategori)}

Pada pembahasan sebelumnya, grafik lingkaran frekuensi hanya melibatkan satu variabel kategori. Sementara pada bagian ini, pembuatan grafik lingkaran frekuensi melibatkan dua variabel kategori. Perhatikan Gambar 5.9 dan Gambar 5.10. 

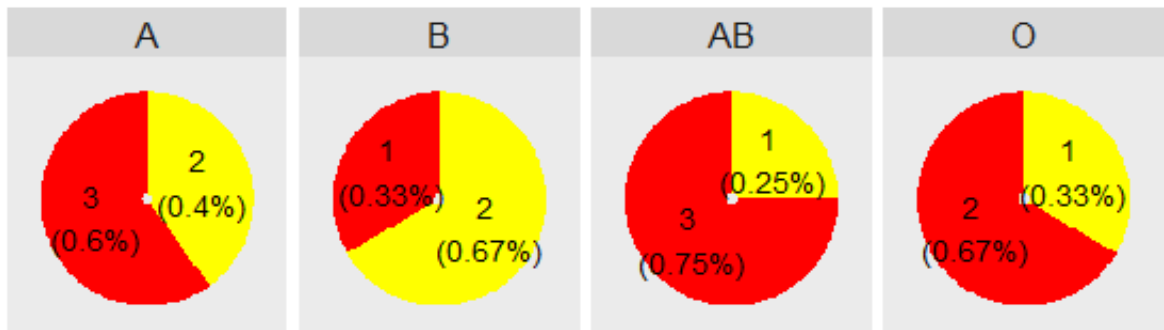

Gambar 5.9 Grafik Lingkaran Frekuensi berdasarkan

Golongan Darah dan Jenis Kelamin

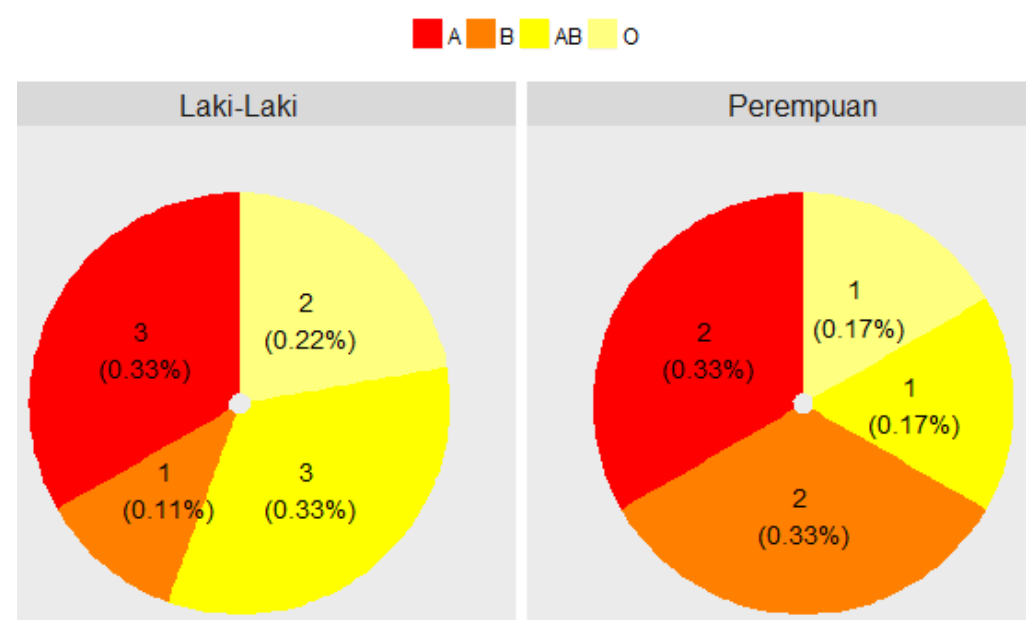

\section{Gambar 5.10 Grafik Batang Frekuensi berdasarkan Golongan Darah dan Jenis Kelamin}

Berdasarkan grafik lingkaran frekuensi pada Gambar 5.9, diketahui dari 5 siswa dengan golongan darah A, $3(60 \%)$ di antaranya dengan jenis kelamin laki-laki, sementara 2 (40\%) perempuan. Untuk membuat grafik lingkaran frekuensi seperti pada Gambar 5.9 dan Gambar 5.10, pilih Circle $=>$ Frequency (Gambar 5.1). Kemudian pilih Input: Two Variables => Circle I (Gambar 5.11). Selanjutnya, pindahkan variabel golongan darah ke kotak sebelah kanan (kotak atas) dan pindahkan variabel jenis kelamin ke kotak sebelah kanan (kotak bawah). Hasilnya dapat dilihat pada bagian Result. Berbagai pengaturan grafik lingkaran frekuensi dapat dilakukan pada bagian Result, mulai dari warna lingkaran, menampilkan frekuensi, judul, dan sebagainya. Di samping itu, terdapat menu Watch Tutorial Video. Di dalam menu Watch Tutorial Video disisipkan video yang dapat diputar dengan syarat 
terkoneksi internet. Video tersebut akan memandu Anda langkah-langkah membuat grafik lingkaran frekuensi terkait.

\section{Circle I}

Input: One Categorical Variable and One Categorical Variable

Choose Variable Result Watch Tutorial Videc

Choose Categorical Variable (Single Choice)

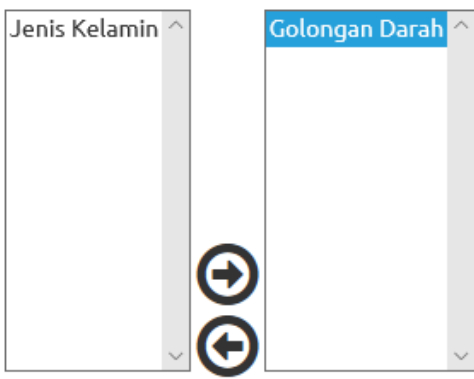

Choose Cattegorical Variable (Single Choice)

Golongan Darah ^ Jenis Kelamin

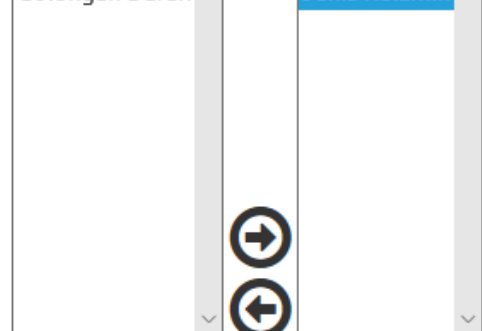

Gambar 5.11 Circle I: Frequency

Input: One Categorical Variable and One Categorical Variable 


\section{BAB 6}

\section{MEMBUAT GRAFIK BOXPLOT}

\subsection{Membuat Grafik Boxplot (Input: Lebih Dari Satu Variabel Numerik)}

Grafix boxplot dapat digunakan untuk melihat sebaran data terhadap rata-ratanya. Apakah suatu data menyebar cukup jauh atau dekat terhadap rata-ratanya dapat dilihat secara visual melalui grafik boxplot. Grafik boxplot pada STATCAL-VISUALIZATION terdapat dua menu input, yakni Input: Multiple Numeric Variables dan Input: Multiple Numeric Variables and One Categorical Variable (Gambar 6.1).

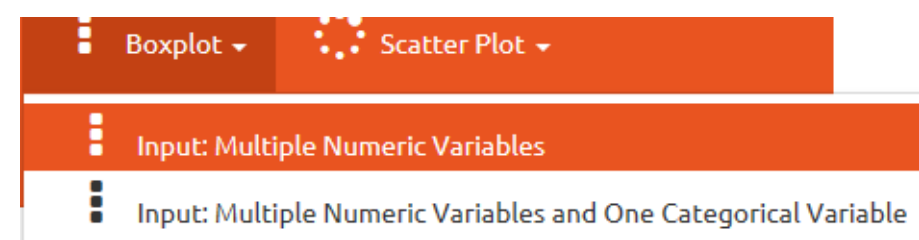

\section{Gambar 6.1}

Gambar 6.2 merupakan grafik boxplot untuk nilai matematika, fisika, kimia dan biologi. Dari grafik boxplot tersebut, dapat dilihat sebaran data (titik-titik) berdasarkan nilai matematika, fisika, kimia dan biologi. Perhatikan bahwa terdapat data ekstrim pada nilai biologi, yakni ditandai dengan titik berwarna merah. Data esktrim tersebut menyebar cukup jauh dari rataratanya. Untuk membuat grafik boxplot tersebut, pilih Boxplot => Input: Multiple Numeric Variables (Gambar 6.1). Selanjutnya pada Choose Numeric Variable (Multiple Choices) masukkan variabel matematika, fisika, kimia dan biologi ke kotak sebelah kanan (Gambar 6.3). Hasil dari grafik boxplot dapat dilihat pada bagian Result. Berbagai pengaturan dari grafik boxplot, seperti warna, sebaran data, dan sebagainya, dapat diatur pada bagian Result. Di samping itu terdapat menu Watch Tutorial Video yang di dalamnya terdapat video tutorial yang memaparkan langkah demi langkah membuat grafik terkait. 


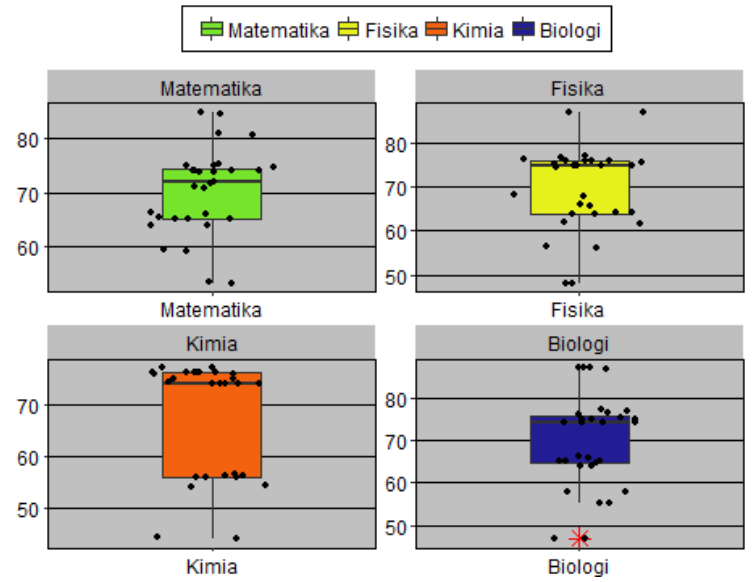

Gambar 6.2 Grafik Boxplot berdasarkan Nilai Matematika, Fisika, Kimia dan Biologi

\section{Boxplot I}

Input: Multiple Numeric Variables

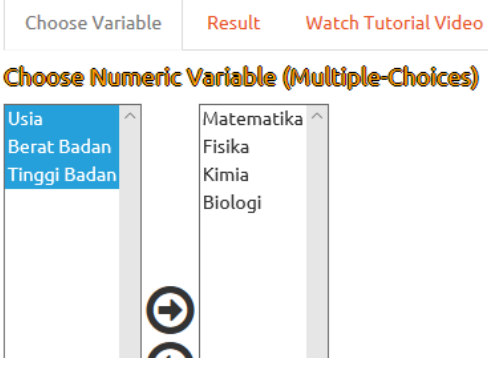

Gambar 6.3 Boxplot: I

Input: Multiple Numeric Variables

6.2 Membuat Grafik Boxplot (Input: Satu Variabel Kategori dan Lebih dari Satu Variabel Numerik)

Grafix boxplot kali ini melibatkan 1 variabel kategori, yakni jenis kelamin dan 4 variabel numerik, yakni nilai matematika, fisika, kimia dan biologi (Gambar 6.4). Untuk membuat grafik boxplot tersebut, pilih Boxplot => Input: Multiple Numeric Variables and One Categorical Variable (Gambar 6.1). Selanjutnya pada Choose Numeric Variable (Multiple Choices) masukkan variabel matematika, fisika, kimia dan biologi ke kotak sebelah kanan, sementara pada Choose Categorical Variable (Single Choice) masukkan variabel jenis kelamin (Gambar 6.5). 


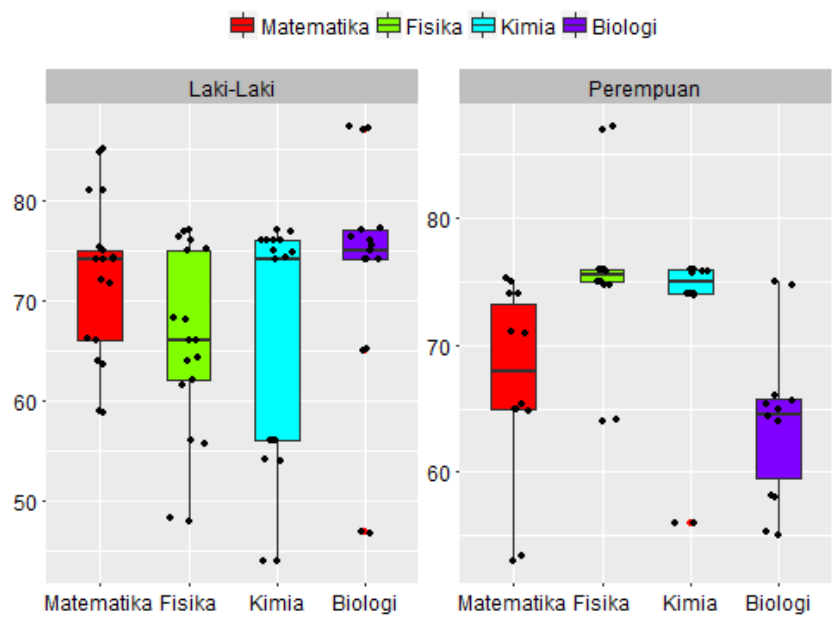

\section{Gambar 6.4 Grafik Boxplot berdasarkan Nilai Matematika, Fisika, Kimia dan Biologi berdasarkan Jenis Kelamin}

Hasil dari grafik boxplot dapat dilihat pada bagian Result. Berbagai pengaturan dari grafik boxplot, seperti warna, sebaran data, dan sebagainya, dapat diatur pada bagian Result. Di samping itu terdapat menu Watch Tutorial Video yang di dalamnya terdapat video tutorial yang memaparkan langkah demi langkah membuat grafik terkait.

Boxplot I

Input: Multiple Numeric Variables and One Categorical Variable

\begin{tabular}{l|ll} 
Choose Variable & Result Watch Tutorial Video
\end{tabular}

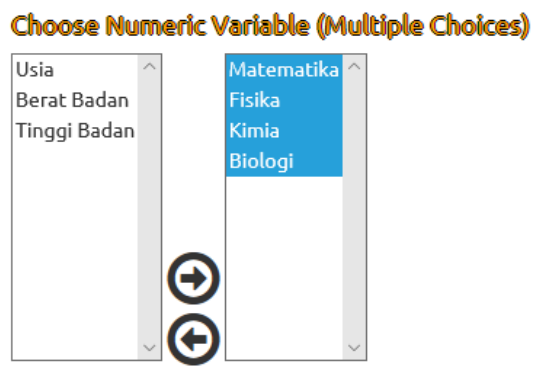

Choose Categorical Variable (Single Choice)

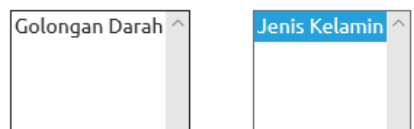

Gambar 6.5 Boxplot: I

Input: Multiple Numeric Variables and One Categorical Variable 


\section{BAB 7}

\section{MEMBUAT GRAFIK SCATTER PLOT}

Scatter Plot dalam STATCAL-VISUALIZATION memiliki 2 menu input, pertama Input:

One Numeric Variable and One Numeric Variable, kedua Input One Numeric Variable and Multiple Numeric Variables (Gambar 7.1).

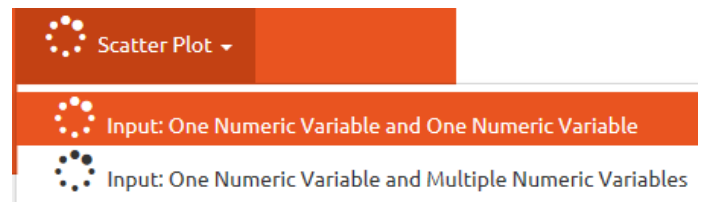

Gambar 7.1 Menu Scatter Plot

Scatter plot menampilkan sebaran data dari dua variabel. Gambar 7.2 disajikan scatter plot antara variabel pendapatan dan pengeluaran.

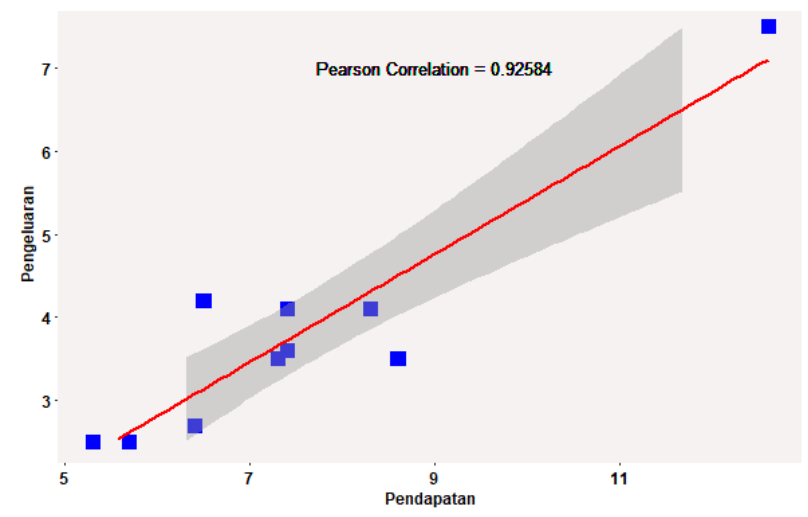

Gambar 7.2 Sebaran Data antara Pendapatan dan Pengeluaran

Berdasarkan scatter plot pada Gambar 7.2, sebaran data cenderung menyebar dari kiri bawah ke kanan atas. Atau terdapat kecenderungan, ketika pendapatan meningkat, pengeluaran juga 
cenderung meningkat. Dengan kata lain terdapat korelasi/hubungan positif antara pendapatan dan pengeluaran. Misalkan data diberikan pada Tabel 7.1.

Tabel 7.1 Data Pengeluaran, Pendapatan dan Jumlah Anak dari 10 Keluarga (Data Fiktif)

\begin{tabular}{|c|c|c|c|}
\hline Responden & $\begin{array}{c}\text { Pengeluaran } \\
\text { (dalam jutaan) }\end{array}$ & $\begin{array}{c}\text { Pendapatan } \\
\text { (dalam jutaan) }\end{array}$ & Jumlah Anak \\
\hline 1 & 3.5 & 8.6 & 3 \\
\hline 2 & 4.2 & 6.5 & 3 \\
\hline 3 & 3.5 & 7.3 & 2 \\
\hline 4 & 2.7 & 6.4 & 2 \\
\hline 5 & 7.5 & 12.6 & 7 \\
\hline 6 & 2.5 & 5.3 & 1 \\
\hline 7 & 4.1 & 8.3 & 5 \\
\hline 8 & 3.6 & 7.4 & 2 \\
\hline 9 & 2.5 & 5.7 & 1 \\
\hline 10 & 4.1 & 7.4 & 4 \\
\hline
\end{tabular}

\section{Numeric Data}

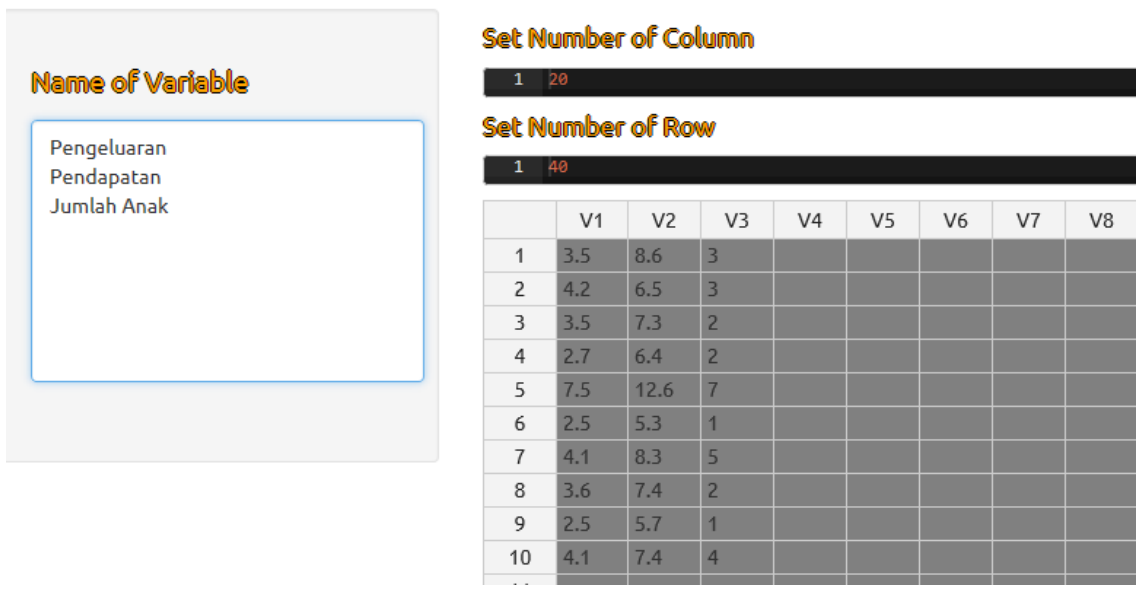

Gambar 7.3 Input Data Numerik

Untuk membuat scatter plot seperti pada Gambar 7.2, terlebih dahulu input data pada Tabel

7.1 seperti pada Gambar 7.3. Pilih Scatter Plot => Input: One Numeric Variable and One Numeric Variable (Gambar 7.1). Pada kotak Choose Numeric Variable (Single Choice) (X-Axis), pindahkan variabel pendapatan ke kotak sebelah kanan, sementara pada kotak 
Choose Numeric Variable (Single Choice) (Y-Axis), pindahkan variabel pengeluaran ke kotak sebelah kanan. Hasilnya dapat dilihat pada bagian Result. Berbagai pengaturan untuk scatter plot dapat dilakukan pada bagian Result (Gambar 7.5).

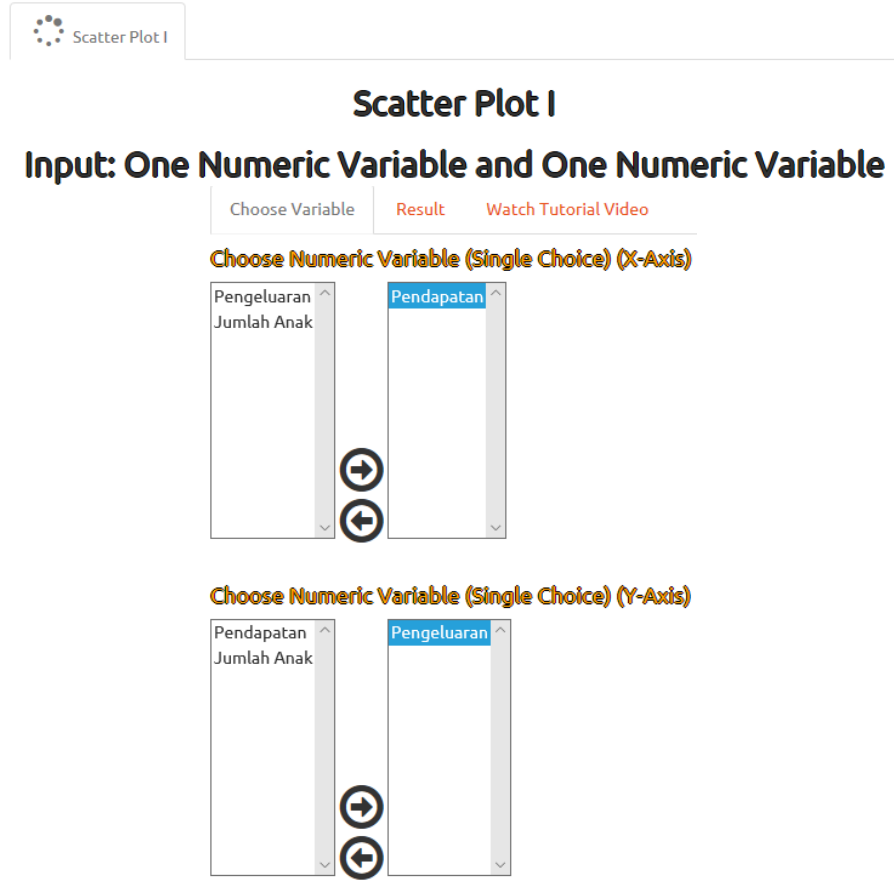

Gambar 7.4 Scatter Plot I Input: One Numeric Variable and One Numeric Variable

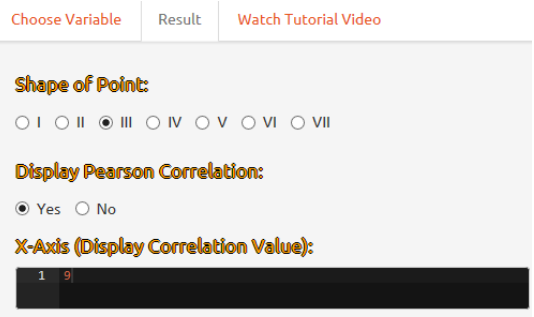

Y-Axis (Display Correlation Value):

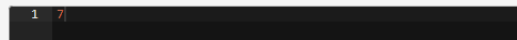

Displasy the Line:

- Yes $O$ No

Color of Pointe

$\bigcirc$ Black $\bigcirc$ Red $\odot$ Blue $\bigcirc$ Green $\bigcirc$ Pink $\bigcirc$ orange $\bigcirc$ Purple

$\bigcirc$ Yellow $O$ Grey

Color of Line:

$\bigcirc$ Black $\odot$ Red $\bigcirc$ Blue $\bigcirc$ Green $\bigcirc$ Pink $\bigcirc$ Orange $\bigcirc$ Purple

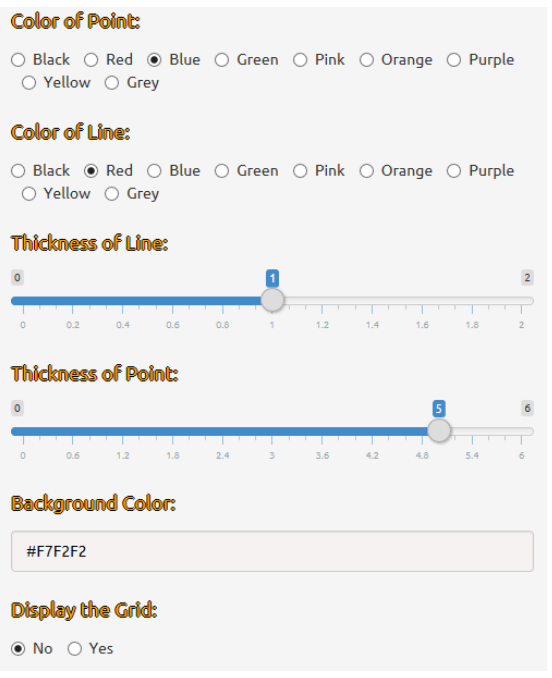

Gambar 7.5 Berbagai Pengaturan Scatter Plot pada Bagian Result 
Gambar 7.6 juga merupakan scatter plot yang menyajikan sebaran data variabel pendapatan dan jumlah anak sebagai sumbu-x, sementara variabel pengeluaran sebagai sumbu-y.

\section{Scatter Plot I}

Input: One Numeric Variable and Multiple Numeric Variables

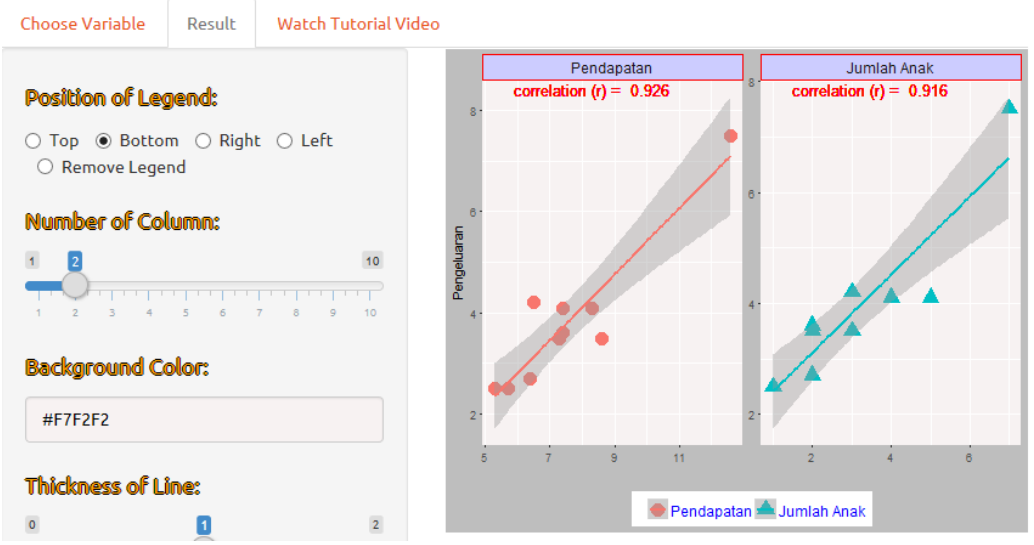

Gambar 7.6 Scatter Plot I

Input: One Numeric Variable and Multiple Numeric Variables

Untuk membuat scatter plot seperti pada Gambar 7.6, pilih menu Input: One Numeric Variable and Multiple Numeric Variables (Gambar 7.1). Pada Choose Numeric Variable (Multiple Choices) (X-Axis), pindahkan variabel pendapatan dan jumlah anak ke kotak sebelah kanan, sementara pada Choose Numeric Variable (Single Choice) (Y-Axis) (Gambar 7.7). Hasil dari scatter plot dapat dilihat pada bagian Result.

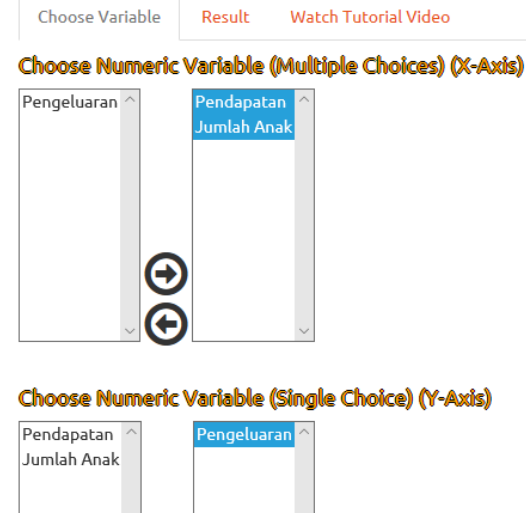

Gambar 7.7 Scatter Plot I Input: One Numeric Variable and Multiple Numeric Variables 


\section{BAB 8}

\section{KORELASI PEARSON}

Korelasi Pearson merupakan suatu nilai yang mengukur seberapa erat hubungan antara dua variabel. Hubungan yang dimaksud di sini adalah hubungan linear. Nilai korelasi Pearson berkisar dari -1 sampai dengan 1. Nilai korelasi Pearson yang semakin dekat dengan -1 atau 1 menandakan semakin kuat hubungan linear antara dua variabel tersebut. Sementara nilai korelasi Pearson yang semakin dekat dengan 0 menandakan semakin lemah hubungan linear antara dua variabel tersebut. Misalkan diberikan data mengenai skor kinerja, motivasi, stres dan tinggi badan berdasarkan 10 responden (Tabel 8.1).

Tabel 8.1 Data Kinerja, Motivasi, Stres dan Tinggi Badan berdasarkan 10 Responden (Data Fiktif)

\begin{tabular}{|c|c|c|c|c|}
\hline Responden & Kinerja & Motivasi & Stres & Tinggi Badan \\
\hline 1 & 65 & 67 & 65 & 165.45 \\
\hline 2 & 87 & 85 & 56 & 174.34 \\
\hline 3 & 54 & 58 & 64 & 164.45 \\
\hline 4 & 64 & 61 & 67 & 185.45 \\
\hline 5 & 84 & 80 & 49 & 174.34 \\
\hline 6 & 57 & 64 & 63 & 174.45 \\
\hline 7 & 74 & 71 & 57 & 174.45 \\
\hline 8 & 82 & 82 & 45 & 174.34 \\
\hline 9 & 61 & 60 & 65 & 181.34 \\
\hline 10 & 67 & 55 & 67 & 164.45 \\
\hline
\end{tabular}

Berdasarkan data pada Tabel 8.1, misalkan ingin diketahui variabel mana yang memiliki hubungan paling erat terhadap kinerja. Apakah motivasi, stres atau tinggi badan? Sekali lagi, hubungan yang dimaksud di sini adalah hubungan linear. Gambar 8.1 disajikan grafik sebaran data dengan kinerja sebagai sumbu-y, sementara motivasi, stres dan tinggi badan sebagai sumbu-x. 


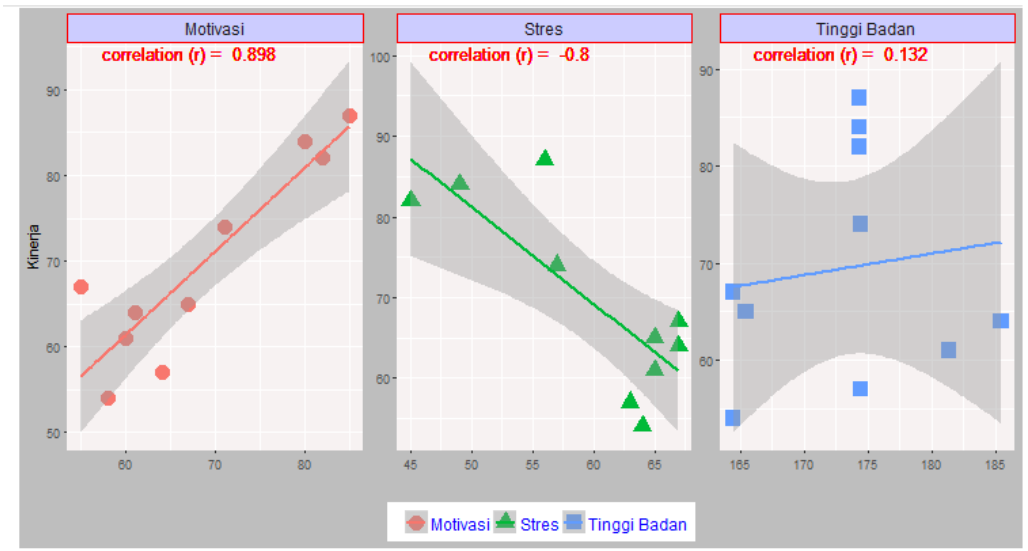

\section{Gambar 8.1 Sebaran Data antara Motivasi, Stres dan Tinggi Badan terhadap Kinerja}

Berdasarkan grafik sebaran data pada Gambar 8.1 diketahui:

$\Rightarrow$ Sebaran data antara motivasi dan kinerja cenderung menyebar dari kiri bawah ke kanan atas. Dengan kata lain motivasi memiliki hubungan atau korelasi positif terhadap kinerja. Terdapat kecenderungan motivasi yang semakin meningkat, diikuti dengan peningkatan kinerja. Diketahui nilai korelasi Pearson (nilai keeratan linear) antara motivasi dan kinerja adalah 0,898 .

$\Rightarrow$ Sebaran data antara stres dan kinerja cenderung menyebar dari kiri atas ke kanan bawah. Dengan kata lain stres memiliki hubungan atau korelasi negatif terhadap kinerja. Terdapat kecenderungan stres yang semakin meningkat, diikuti dengan penurunan kinerja. Diketahui nilai korelasi Pearson (nilai keeratan linear) antara stres dan kinerja adalah $-0,8$.

$\Rightarrow$ Sebaran data antara tinggi dan kinerja cenderung menyebar dari kiri bawah ke kanan atas. Dengan kata lain tinggi badan memiliki hubungan atau korelasi positif terhadap kinerja. Terdapat kecenderungan tinggi badan yang semakin meningkat, diikuti dengan peningkatan kinerja. Diketahui nilai korelasi Pearson (nilai keeratan linear) antara tinggi badan dan kinerja adalah 0,132 . 
Berdasarkan uraian di atas, varaibel pertama yang memiliki keeratan linear paling kuat terhadap kinerja adalah motivasi, dengan nilai korelasi Pearson 0,898 , sementara yang kedua adalah stres, dengan nilai korelasi Pearson -0,8. Gambar 8.2 disajikan nilai korelasi Pearson antar variabel. Diketahui nilai korelasi Pearson antara motivasi dan kinerja adalah 0,898, stres dan kinerja adalah $-0,8$, serta tinggi badan dan kinerja adalah 0,132 . Untuk membuat tampilan korelasi seperti pada Gambar 8.2, input data Tabel 8.1 terlebih dahulu (Gambar 8.3). Selanjutnya pilih Correlation Plot $=>$ Correlation Plot (Gambar 8.4). Pada Choose Numeric Variable (Multiple Choices), pindahkan variabel kinerja, motivasi, stres dan tinggi badan ke kotak sebelah kanan. Hasil korelasi dapat dilihat pada bagian Result.

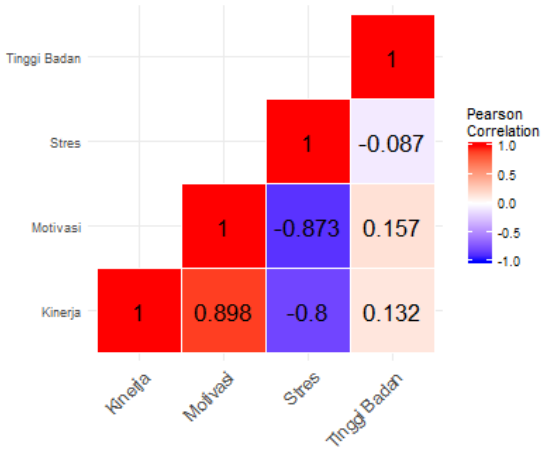

Gambar 8.2 Korelasi Pearson antar Variabel

\section{Numeric Data}

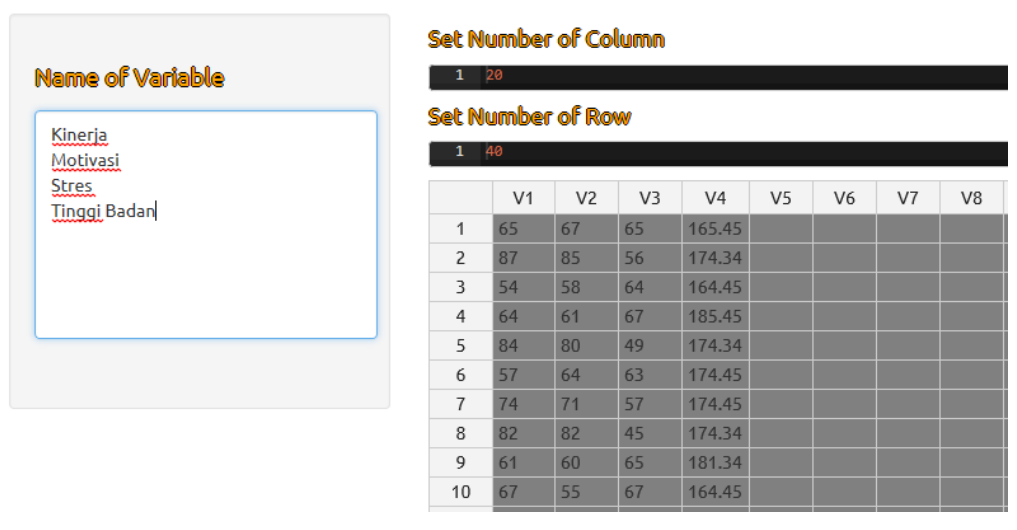

Gambar 8.3 Input Data Numerik 


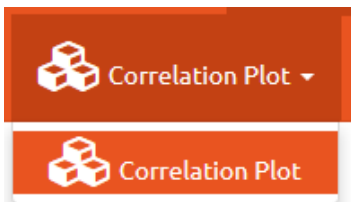

\section{Gambar 8.4 Menu Korelasi}

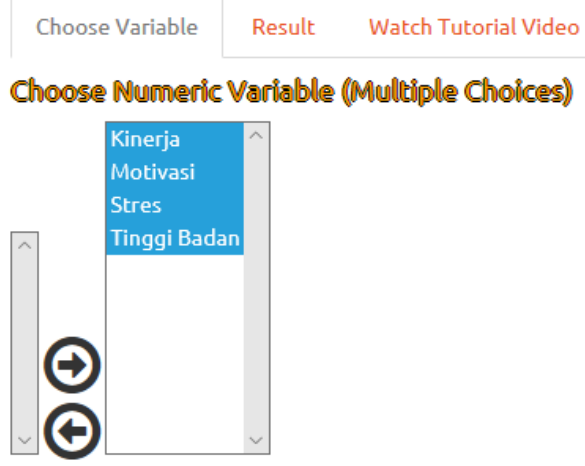

Gambar 8.5 Correlation 


\section{BAB 9}

\section{GRAFIK TIME SERIES}

\subsection{Membuat Grafik Time Series I}

Pada pembahasan kali ini, akan dipaparkan bagaimana membuat berbagai grafik time series.

Misalkan diberikan contoh data hasil penjualan mobil A, B dan C mulai dari tahun 2010 sampai dengan tahun 2011 (Tabel 9.1).

Tabel 9.1 Jumlah Mobil A, B dan C yang Terjual dari Tahun 2010-2011

\begin{tabular}{|c|c|c|c|}
\hline Waktu & Mobil A & Mobil B & Mobil C \\
\hline 1-Jan-2010 & 12 & 16 & 21 \\
\hline 1-Feb-2010 & 15 & 12 & 19 \\
\hline 1-Mar-2010 & 17 & 15 & 12 \\
\hline 1-Apr-2010 & 21 & 17 & 14 \\
\hline 1-May-2010 & 32 & 21 & 20 \\
\hline 1-Jun-2010 & 38 & 22 & 21 \\
\hline 1-Jul-2010 & 24 & 25 & 15 \\
\hline 1-Aug-2010 & 27 & 21 & 18 \\
\hline 1-Sep-2010 & 19 & 23 & 11 \\
\hline 1-Oct-2010 & 32 & 19 & 23 \\
\hline 1-Nov-2010 & 33 & 28 & 32 \\
\hline 1-Dec-2010 & 39 & 32 & 37 \\
\hline 1-Jan-2011 & 14 & 18 & 24 \\
\hline 1-Feb-2011 & 17 & 14 & 22 \\
\hline 1-Mar-2011 & 19 & 17 & 15 \\
\hline 1-Apr-2011 & 23 & 19 & 17 \\
\hline 1-May-2011 & 34 & 23 & 23 \\
\hline 1-Jun-2011 & 40 & 24 & 24 \\
\hline 1-Jul-2011 & 26 & 27 & 18 \\
\hline 1-Aug-2011 & 29 & 23 & 21 \\
\hline 1-Sep-2011 & 21 & 25 & 14 \\
\hline 1-Oct-2011 & 34 & 21 & 26 \\
\hline 1-Nov-2011 & 35 & 30 & 35 \\
\hline 1-Dec-2011 & 41 & 34 & 40 \\
\hline
\end{tabular}


Berdasarkan data pada Tabel 9.1, diketahui pada 1 Januari 2010, mobil A terjual sebanyak 12 unit, mobil B terjual sebanyak 16 unit dan mobil $\mathrm{C}$ terjual sebanyak 21 unit. Gambar 9.1 disajikan berbagai grafik time series mengenai jumlah mobil $\mathrm{A}, \mathrm{B}$ dan $\mathrm{C}$ yang terjual dari tahun 2010 hingga tahun 2011.

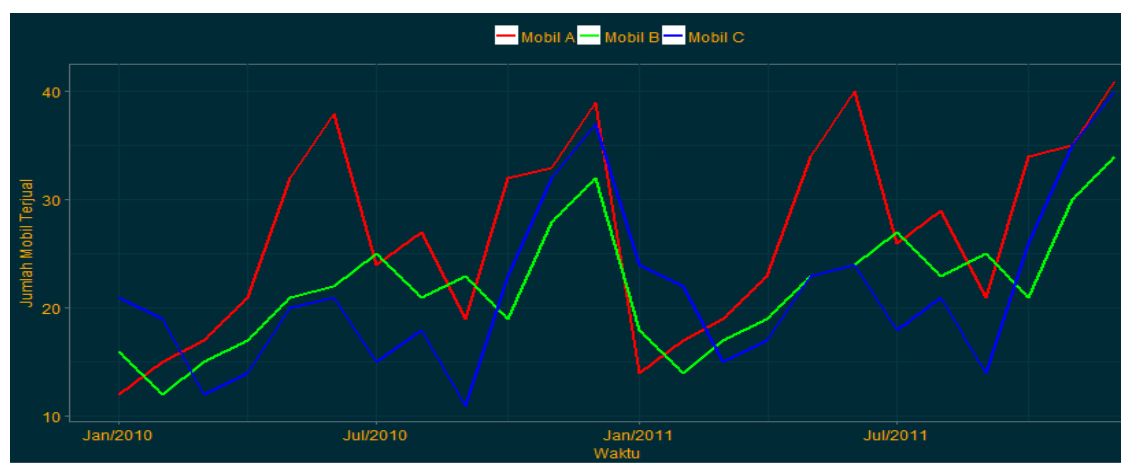

曰Mobil A

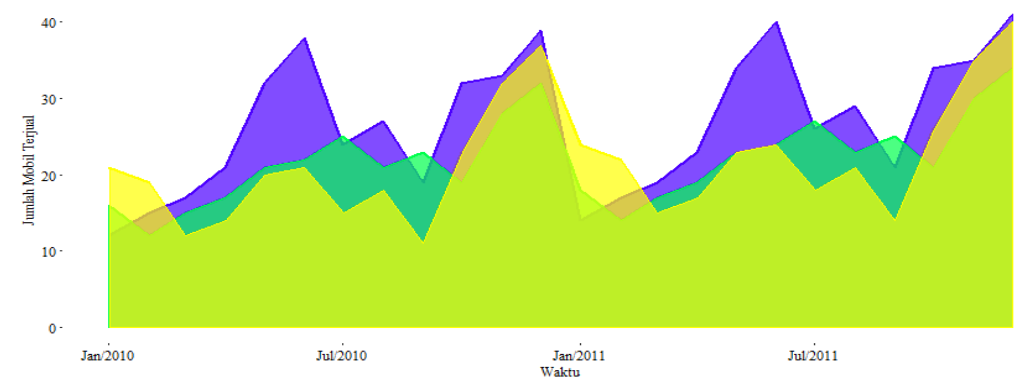

$\because$ Mobil A - Mobil B $\square$ Mobil C

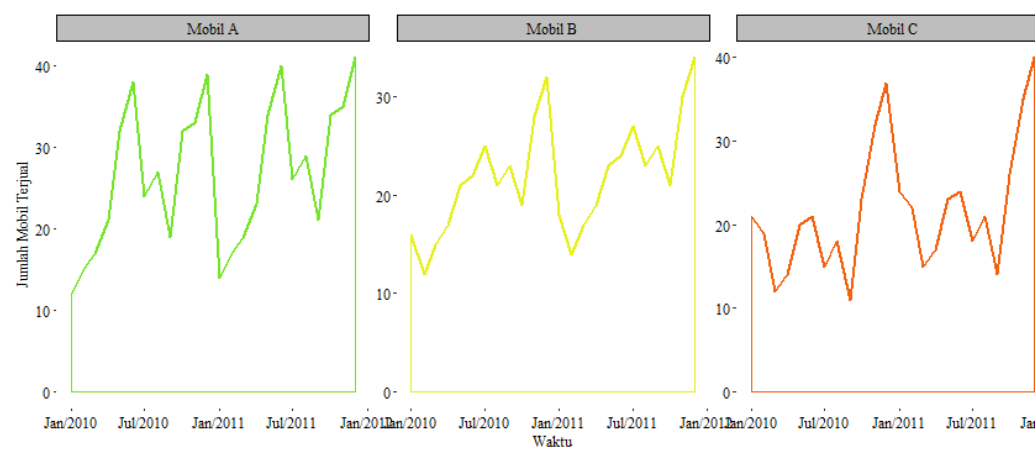

플il A $=$ Mobil B - Mobil C

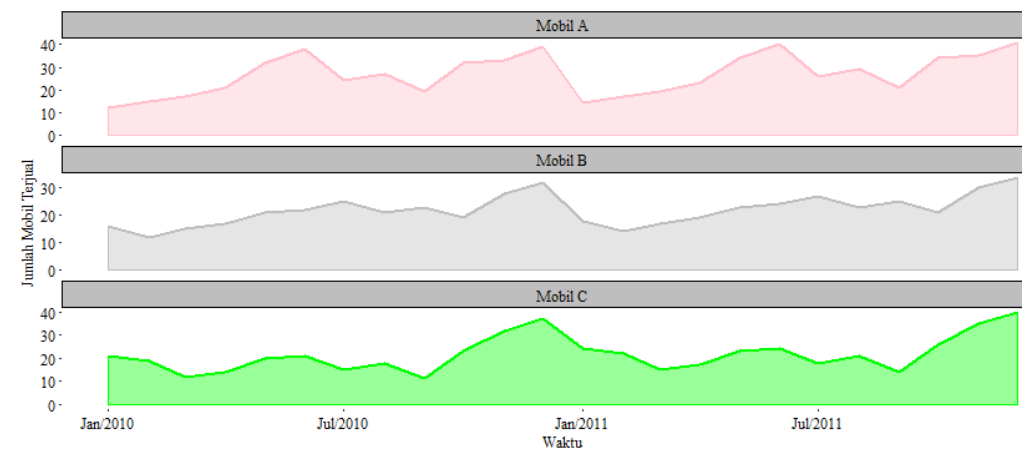

Gambar 9.1 Berbagai Grafik Time Series 
Untuk membuat grafik time series seperti pada Gambar 9.1, pilih Time Series => Time Series I (Gambar 9.2).

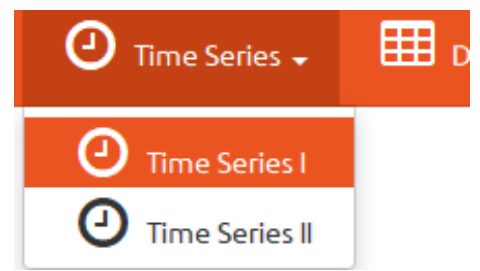

\section{Gambar 9.2 Menu Time Series}

Input data seperti pada Gambar 9.3, Gambar 9.4, dan Gambar 9.5. Pada Gambar 9.6, masukkan variabel mobil A, B dan C ke kotak sebelah kanan Choose Numeric Variable (Multiple Choices), sementara masukkan variabel waktu ke kotak sebelah kanan Choose

\section{Time (Single Choice).}

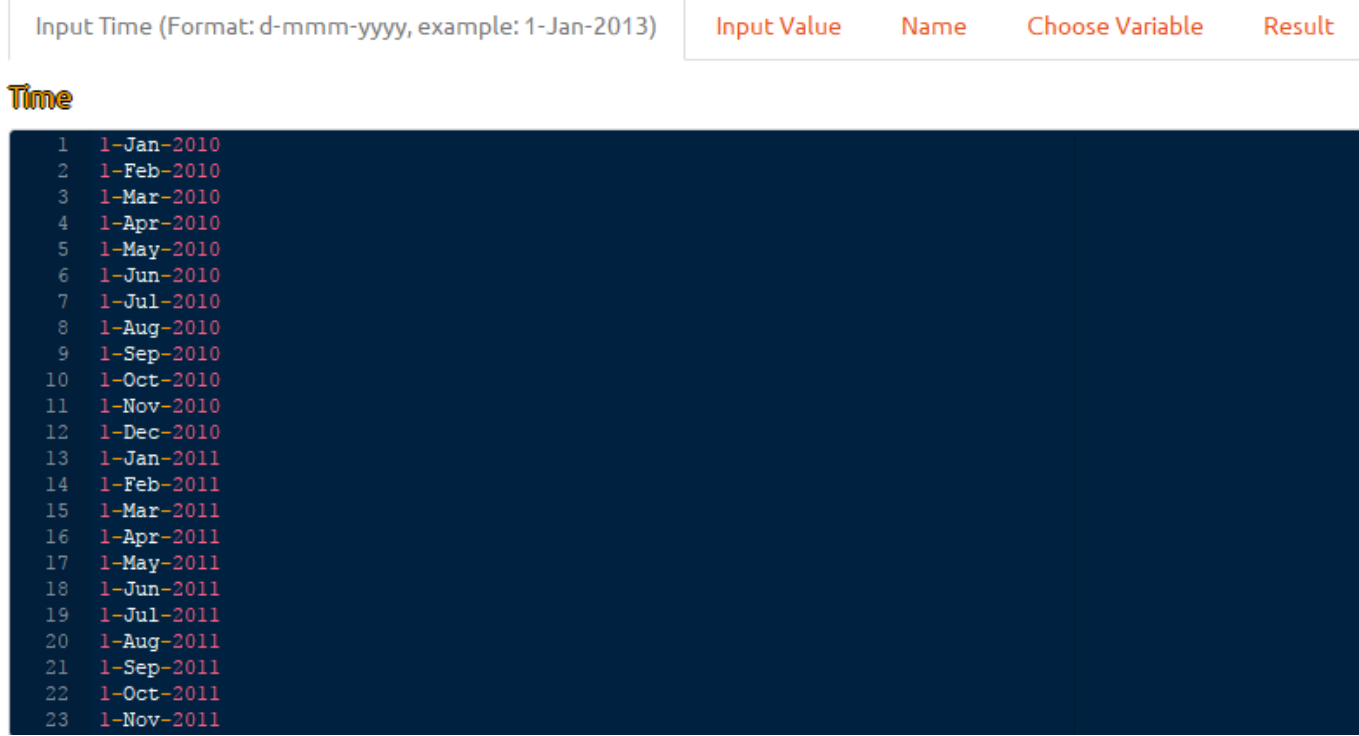

Gambar 9.3 Menginput Data Waktu 
Tione

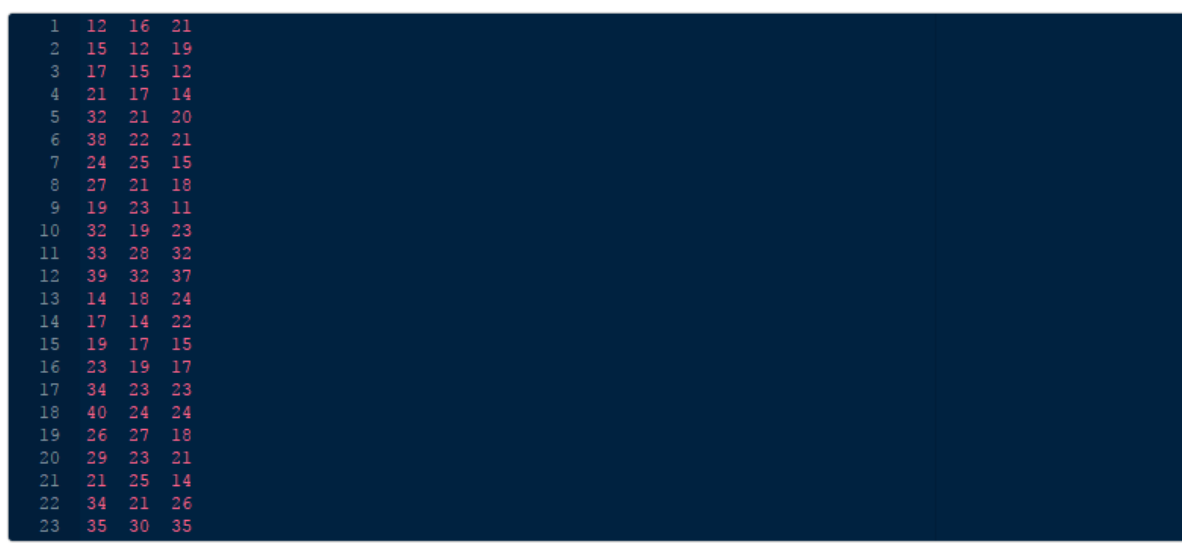

Gambar 9.4 Menginput Data Penjualan Mobil A, B dan C

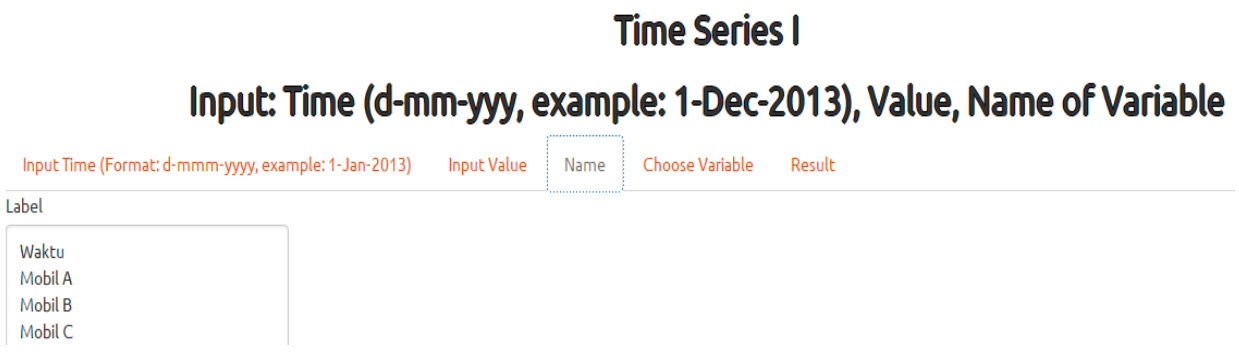

Gambar 9.5 Menginput Nama Variabel

Time Series I

Input: Time (d-mm-yyy, example: 1-Dec-2013), Value, Name of Variable Choose Numeric Variable (Mullipiple Choices)

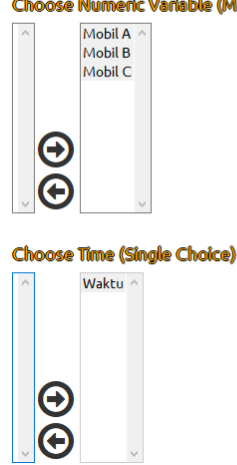

Gambar 9.6 Pemilihan Variabel

Hasil grafik dapat dilihat pada bagian Result (Gambar 9.7). 


\section{Time Series I}

Input: Time (d-mm-yyy, example: 1-Dec-2013), Value, Name of Variable
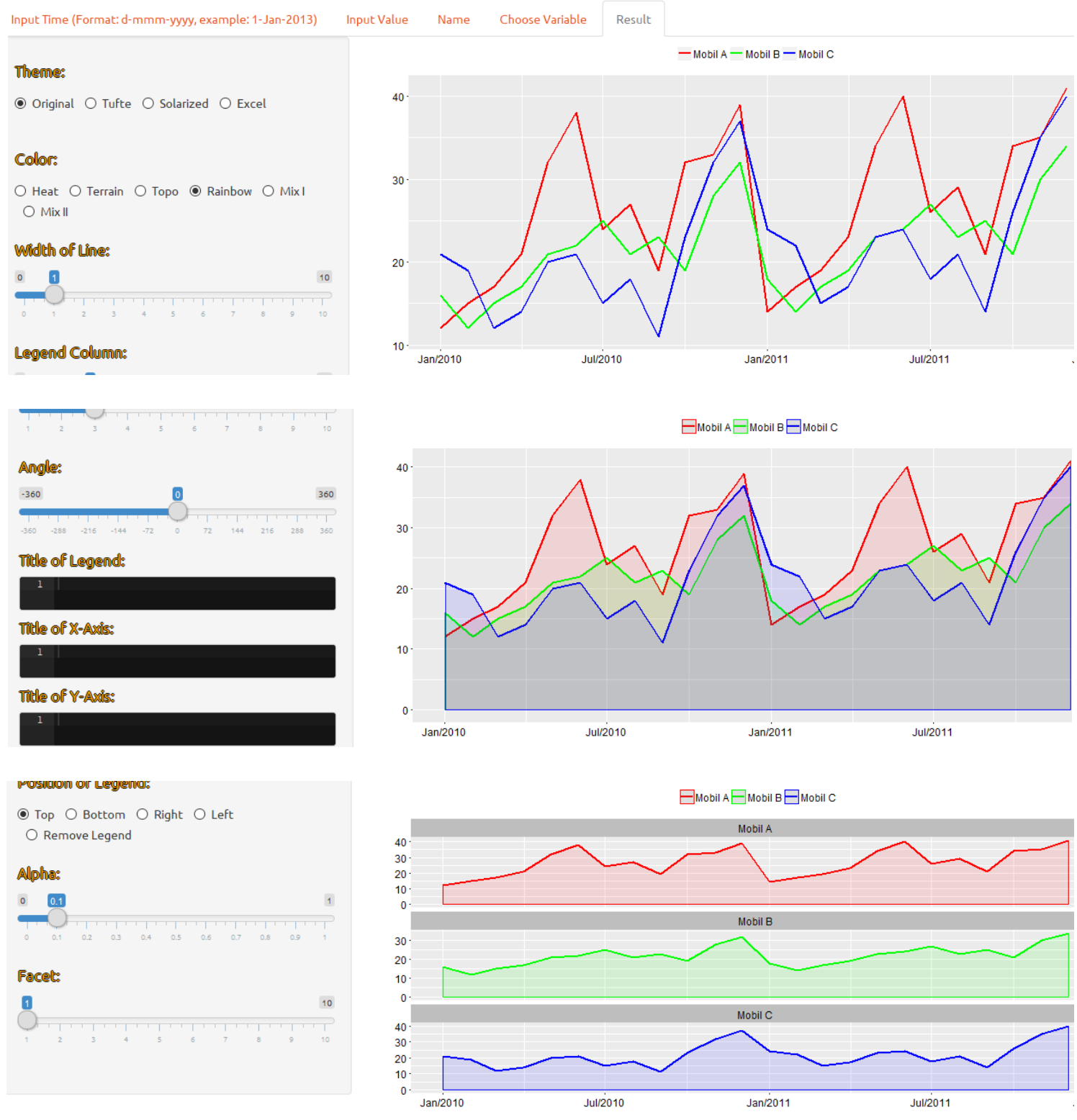

\section{Gambar 9.7 Result}

\subsection{Membuat Grafik Time Series II}

Misalkan diberikan contoh data hasil penjualan mobil A, B dan C mulai dari tahun 2010 sampai dengan tahun 2011 (Tabel 9.2). 
Tabel 9.2 Jumlah Mobil A, B dan C yang Terjual dari Tahun 2010-2011

\begin{tabular}{|c|c|c|c|}
\hline Waktu & Mobil A & Mobil B & Mobil C \\
\hline Januari 2010 & 12 & 16 & 21 \\
\hline Februari 2010 & 15 & 12 & 19 \\
\hline Maret 2010 & 17 & 15 & 12 \\
\hline April 2010 & 21 & 17 & 14 \\
\hline Mei 2010 & 32 & 21 & 20 \\
\hline Juni 2010 & 38 & 22 & 21 \\
\hline Juli 2010 & 24 & 25 & 15 \\
\hline Agustus 2010 & 27 & 21 & 18 \\
\hline September 2010 & 19 & 23 & 11 \\
\hline Oktober 2010 & 32 & 19 & 23 \\
\hline November 2010 & 33 & 28 & 32 \\
\hline Desember 2010 & 39 & 32 & 37 \\
\hline Januari 2011 & 14 & 18 & 24 \\
\hline Februari 2011 & 17 & 14 & 22 \\
\hline Maret 2011 & 19 & 17 & 15 \\
\hline April 2011 & 23 & 19 & 17 \\
\hline Mei 2011 & 34 & 23 & 23 \\
\hline Juni 2011 & 40 & 24 & 24 \\
\hline Juli 2011 & 26 & 27 & 18 \\
\hline Agustus 2011 & 29 & 23 & 21 \\
\hline September 2011 & 21 & 25 & 14 \\
\hline Oktober 2011 & 34 & 21 & 26 \\
\hline November 2011 & 35 & 30 & 35 \\
\hline Desember 2011 & 41 & 34 & 40 \\
\hline
\end{tabular}

Berdasarkan data pada Tabel 9.2, diketahui pada Januari 2010, mobil A terjual sebanyak 12 unit, mobil B terjual sebanyak 16 unit dan mobil C terjual sebanyak 21 unit. Gambar 9.8 disajikan berbagai grafik time series mengenai jumlah mobil $\mathrm{A}, \mathrm{B}$ dan $\mathrm{C}$ yang terjual dari tahun 2010 hingga tahun 2011.

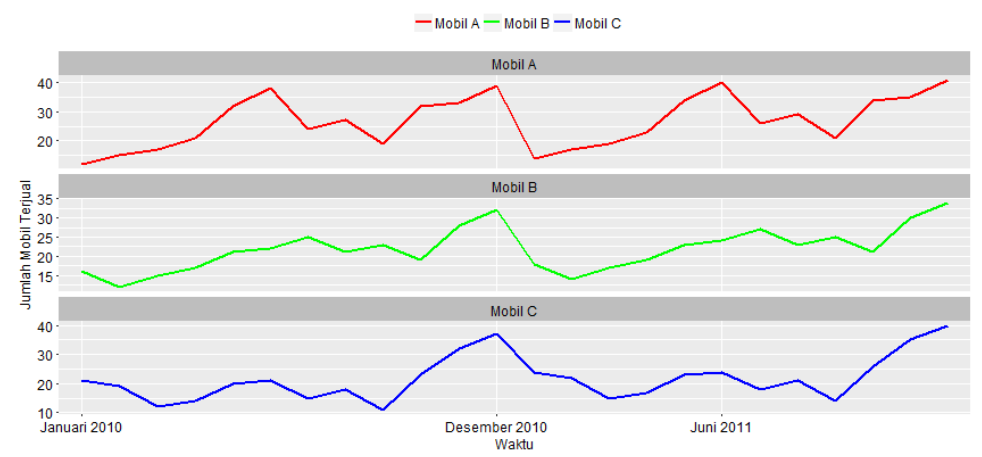



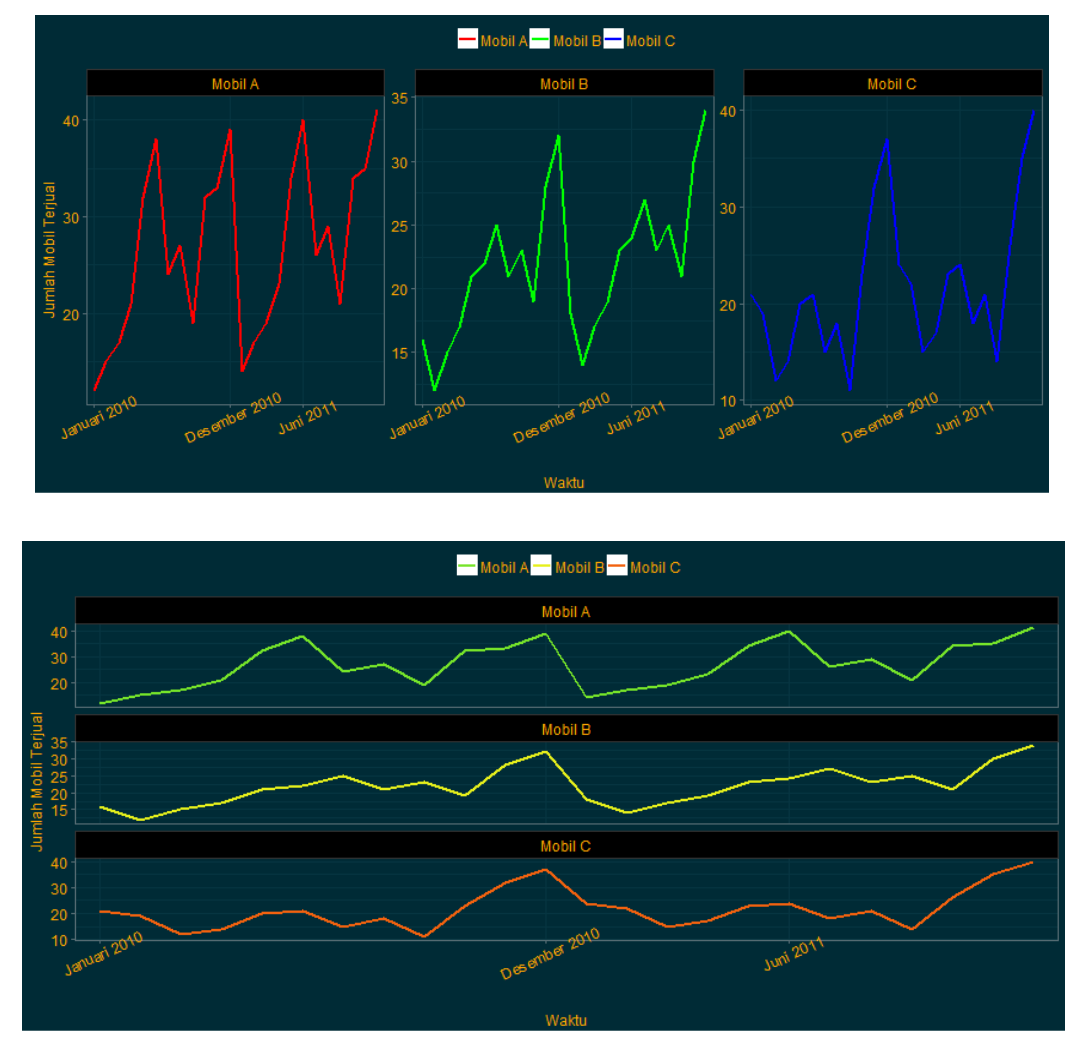

Gambar 9.8 Berbagai Grafik Time Series

Untuk membuat grafik seperti pada Gambar 9.8, pilih Time Series => Time Series II (Gambar 9.2). Input data seperti pada Gambar 9.9, Gambar 9.10, dan Gambar 9.11. Pada Gambar 9.12, masukkan variabel mobil A, B dan C ke kotak sebelah kanan Choose Numeric Variable (Multiple Choices), sementara masukkan variabel waktu ke kotak sebelah kanan Choose Time (Single Choice).

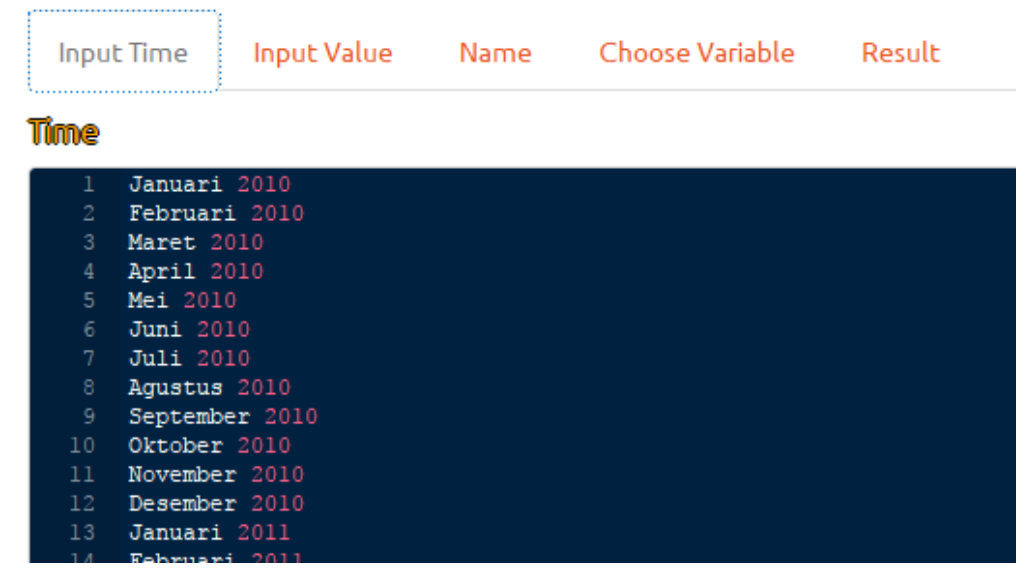

Gambar 9.9 Menginput Data Waktu 


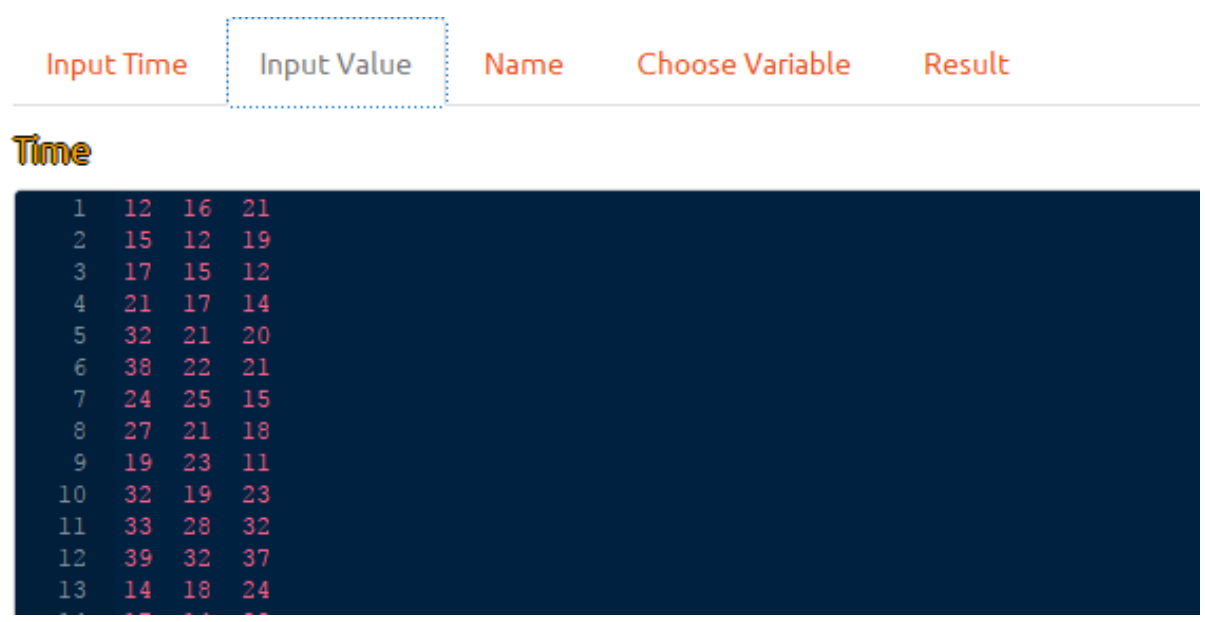

Gambar 9.10 Menginput Data Penjualan Mobil A, B dan C

\begin{tabular}{l|l:|l}
\multicolumn{1}{|c|}{ Input Time Input Value } & Name & Choose Variable Result \\
\hline Label & \\
\hline Waktu & \\
Mobil A & \\
Mobil B \\
Mobil C
\end{tabular}

Gambar 9.11 Menginput Nama Variabel

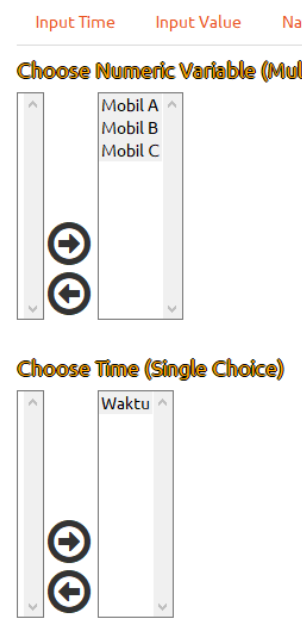

Gambar 9.12 Pemilihan Variabel

Hasil grafik dapat dilihat pada bagian Result. 


\section{Referensi}

http://www.sthda.com/english/wiki/ggplot2-quick-correlation-matrix-heatmap-r-software-and-datavisualization

http://www.sthda.com/english/wiki/ggcorrplot-visualization-of-a-correlation-matrix-using-ggplot2

https://briatte.github.io/ggcorr/

http://jamesmarquezportfolio.com/correlation matrices in r.html

http://a-little-book-of-r-for-time-series.readthedocs.io/en/latest/src/timeseries.html

https://www.r-bloggers.com/plotting-time-series-data-using-ggplot2/

https://www.statmethods.net/advstats/timeseries.html

https://plot.ly/r/time-series/

https://plot.ly/ggplot2/facet/

http://ggplot2.tidyverse.org/reference/facet grid.html

http://cookbook-r.com/Graphs/Facets_(ggplot2)/

http://www.sthda.com/english/wiki/ggplot2-facet-split-a-plot-into-a-matrix-of-panels

https://www3.nd.edu/ steve/computing_with_data/13_Facets/facets.html

https://www3.nd.edu/ steve/computing_with_data/13_Facets/facets.html

http://sape.inf.usi.ch/quick-reference/ggplot2/facet

https://cran.r-project.org/web/packages/shinythemes/index.html

https://cran.r-project.org/web/packages/lavaan/index.html

https://cran.r-project.org/web/packages/plspm/index.html

https://cran.r-project.org/web/packages/ggplot2/index.html

https://cran.r-project.org/web/packages/reshape2/index.html

https://cran.r-project.org/web/packages/dplyr/index.html

https://cran.r-project.org/web/packages/shiny/index.html

https://cran.r-project.org/web/packages/plyr/index.html

https://cran.r-project.org/web/packages/DT/index.html 
https://cran.r-project.org/web/packages/doBy/index.html https://cran.r-project.org/web/packages/GGally/index.html https://cran.r-project.org/web/packages/plotrix/index.html https://cran.r-project.org/web/packages/tseries/index.html https://cran.r-project.org/web/packages/nortest/index.html https://cran.r-project.org/web/packages/car/index.html https://cran.r-project.org/web/packages/RVAideMemoire/index.html https://cran.r-project.org/web/packages/plm/index.html https://cran.r-project.org/web/packages/colourpicker/index.html https://cran.r-project.org/web/packages/psych/index.html https://cran.r-project.org/web/packages/DescTools/index.html https://cran.r-project.org/web/packages/semPlot/index.html 